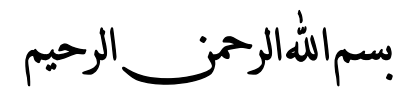

الحمد لله رب العالمين، شرع لنا من الدين ما فيه صلاحنا ومن الأحكــام

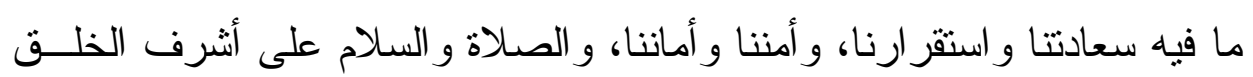

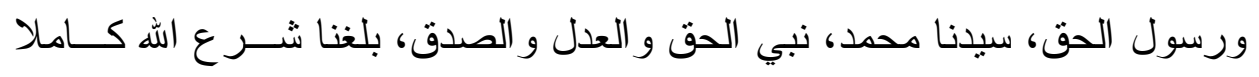

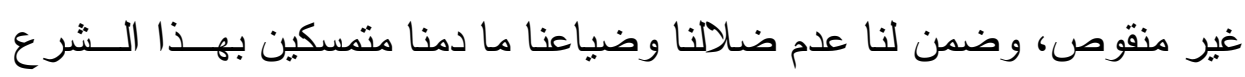
الحنيف حيث يقول النبي لئس

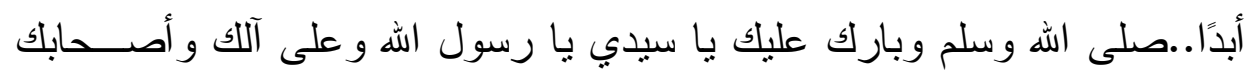

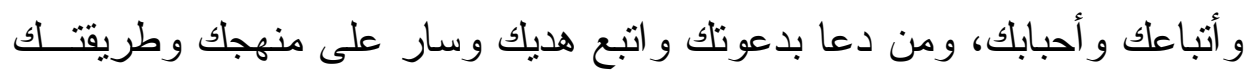

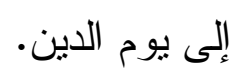

\section{أما بعد}

فلم يتعرض موضوع من موضوعات التشريع الإسلامي مثلما تعرض له

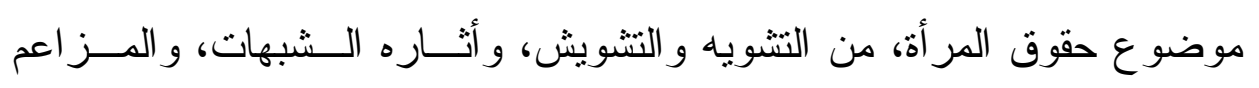

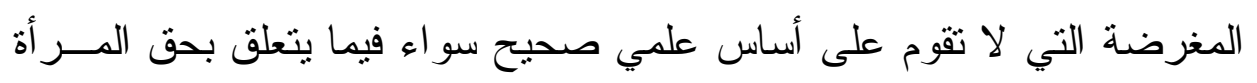

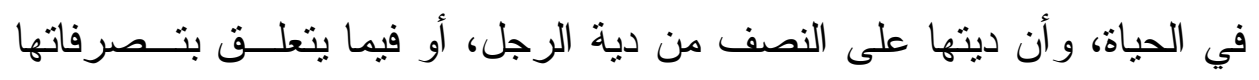

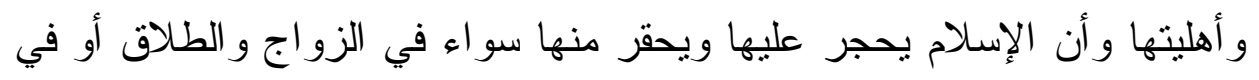

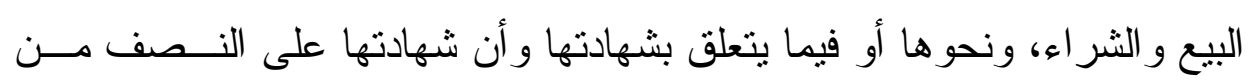

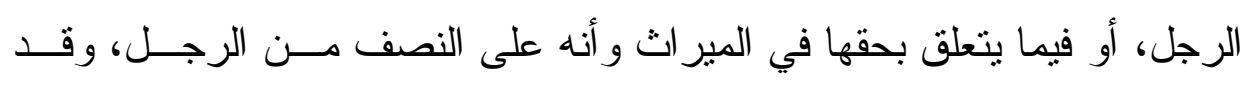

مجلتً البحوث القانونيت والإقتصاديت 
حظي موضو ع مير اث المر أة بالنصيب الأكبر من تلك الحملــة الظالمــة، مــن

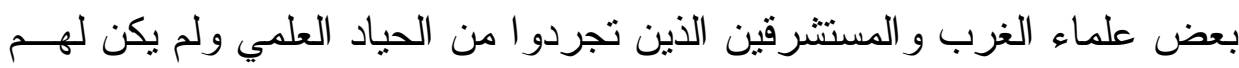

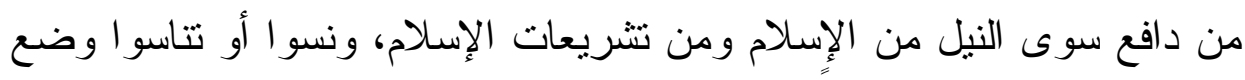

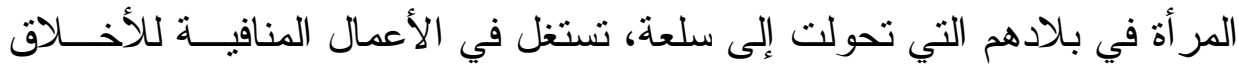

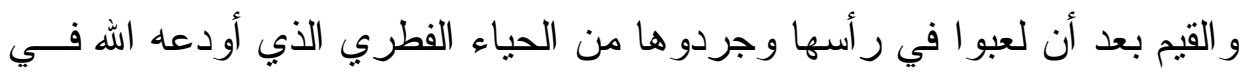

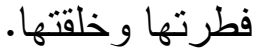

و غاية هذه السطور إماطة اللثنام عن وجه الحقيقة في موضـــوع ميــراث

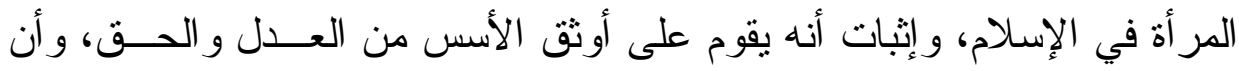

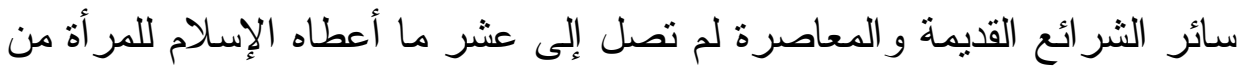

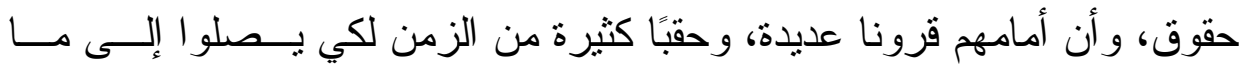
حصلت عليه المر أة من حقوق في ظل التشريع الإسلامي.

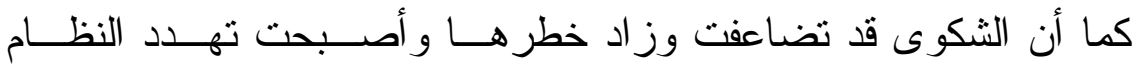

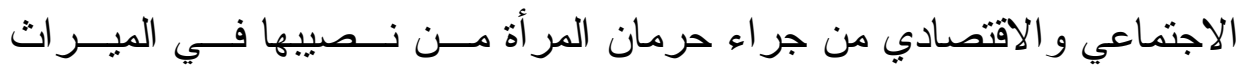
و ازدحمت المحاكم وتر اكمت فيها القضايا التي تتعلق بمير اث المر أة الة.

وسوف يتم تناول هذا الموضوع وفقا للمحاور الآتية: المحور الأول: وضع المر أة في الميراث في الثر ائع الأخرى قديمها وحديثها.

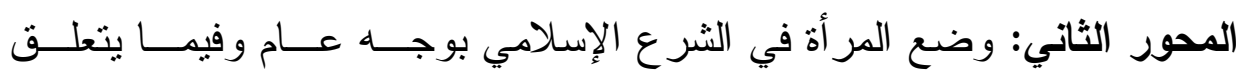

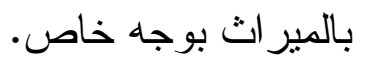


المحور الثالث: خصائص نظام الميراث الإسلامي والأسس التي يقوم عليها. المحور الرابع: أحو ال ميراث المر أة في الثرع الإسلامي.

المحور الخامس: منى يكون مير اث المر أة على النصف من الرجـلـ ولمـــاذا؟،

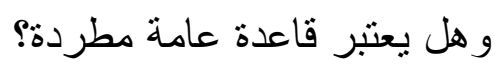

المحور السادس: عقبات ومشكلات في سبيل حصول المر أة علــى حقهــا فــي المير اث وسبل علاجها.

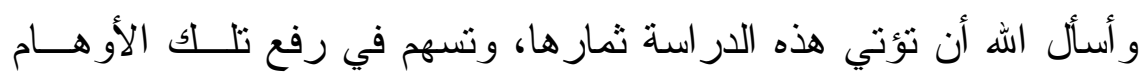
و الثبهات التي توجد في عقول ور عوس القائلين بها و المرددين و المروجين لهــا، أنه من ور اء القصد، وهو وحده الذي يهدي إلى سو اء السبيل قال تعــالى: "نَــن

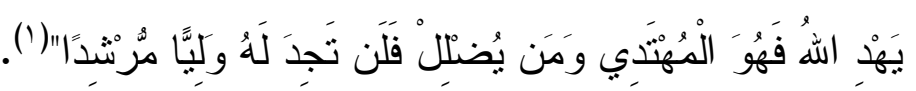

$$
\text { أ.د. الهادي عرفه }
$$

أستاذ الثريعة الإسلامية بكلية الحقوق

\section{جامعة المنصورة}





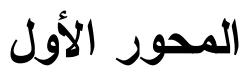

\section{وضع المرأة في الميراث}

\section{في الثرائع الأخرى قديمها وحديثها}

لقد تذبذب وضع المر أة في الميراث في الثر ائع الأخرى بين من يثبت لها

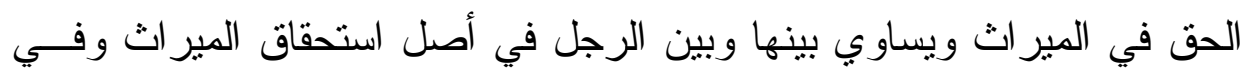
مقداره، ولكن هذه المساو اة ظاهرية وليست حقيقية كما سنرى في مصر القديمسـة

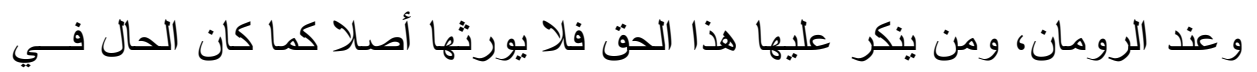

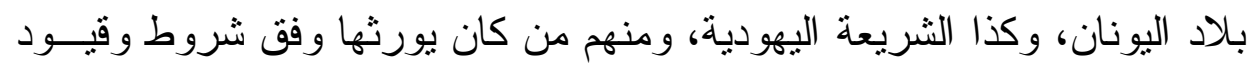

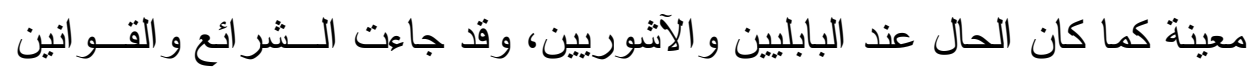

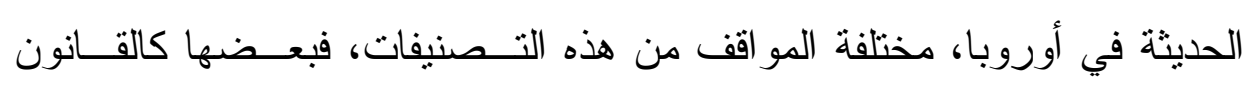

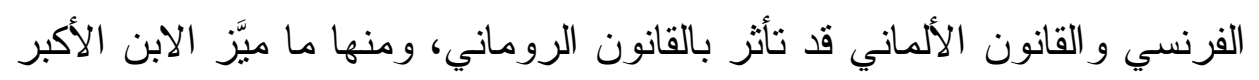

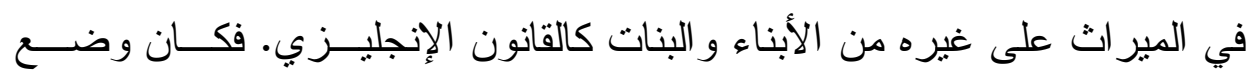

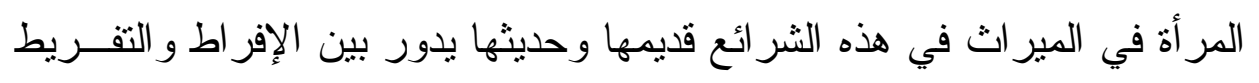
وفقا لما يلي:

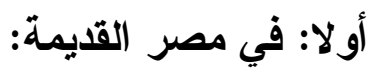

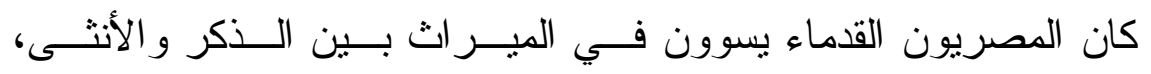
و لا يميزن الذكر على الأنثى، ولا تحجب الأنثى بذكر فـي درجتهــا. وكــانوا 


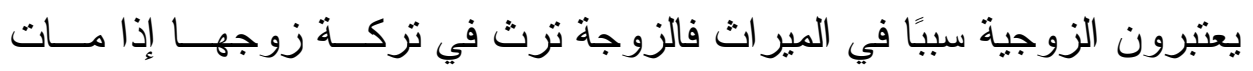
قبلها، و الزوج يرث في تركة زوجته إذا ماتت قبله.

وبالر غم من أنهم كانو ا يسوون بين أو لاد المتــوفى ذكــورًا و إناتــا فــي الأنصبة إلا أن الابن الأكبر كان له امتياز خاص يتمنل في حقه في إدارة التركة كلها عن نفسه وعن إخوته، فإذا انقرض الإخوة قسمت التزكــة بــين فــروعهم

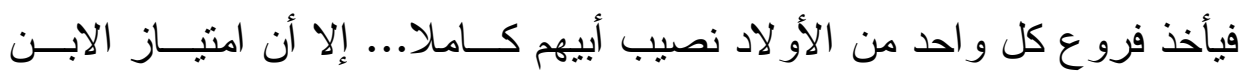

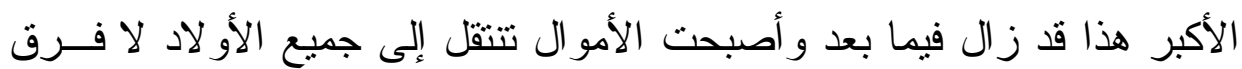
بين كبير وصغير ، و لا بين ذكر و أنثى (؟). ثانيًا: في بلاد العراق وبلاد بابل وآثور:

لم يرد في نصوصهم (قانون حمور ابي) ما يدل علـى ميــر اث الإنـاث وخاصة البنات ولذلك اختلف الر أي في توريثهن، فذهب البعض إلى أنهـن كـنـ

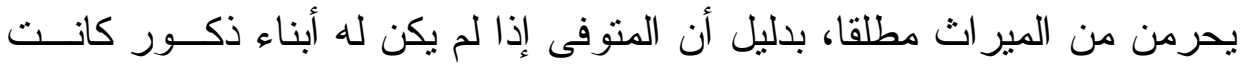

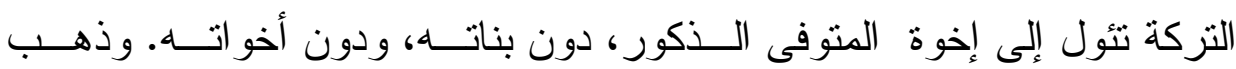
البعض الآخر إلى أنهن كن برثن بشرط عدم وجود أبناء ذكور، و عندئذ يكــون

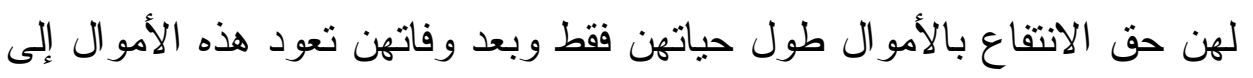
الأسرة، ولا تورث لأو لادهن وذهب البعض الآخر إلى أن البنت كانت ترث في في 


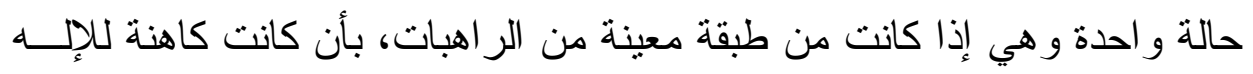

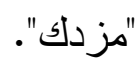

ومما يخفف من غلو اء حرمانها من المير اث أنها كانــت تحــصل علـى ما يُسمى بالدوطة من مال أبيها عند زو اجها، في حــال حياتــهـ أو بنــاء علــى تصرف مضاف إلى الموت في حال وفاته.

وبالنسبة للزوجة كان الأصل عندهم عدم توريثها، اكتفاء بالأمو ال التـي يخصصها لها الزوج في صورة متعة، فإذا لم يخصص لها الزوج مالا للمتعــة، فإنها تحصل من التركة على ما يساوي نصيب أحد الأبناء كحق انتفــاع فقــــ فضلا عن حقها في الاتتفاع بأمو ال دوطتها، طو ال حياتها، فإذا ماتت آلت هــذه

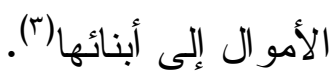
ثالثًا: عند اليونانيين: كان اليونانيون يقدسون العائلة، ولذلك كان نظام الميراث عندهم يقوم على تدعيم العائلة، و عدم خروج الأمو ال من دائرة العائلة ومن ثم كــانو ا يقــصرون المير اث على الأبناء الذكور دون الإناث لأن البنت لو ورثت، فإن مير اثها يعـــ موتها سوف يتول إلى أو لاد ها ومن ثم تتنقل الأمو ال إلى أســرة زوجهــا، و إذا

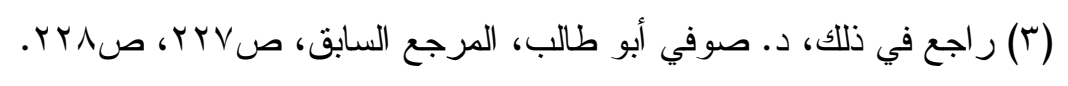

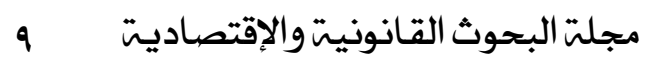


أر ادت البنت أن ترث إذا تزوجت كان يجب عليها أن تتسب ولدها لأمه لأنــه-

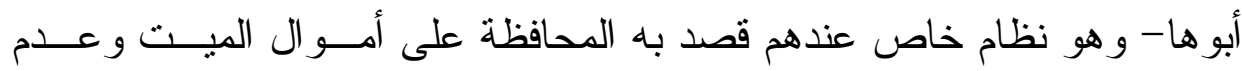

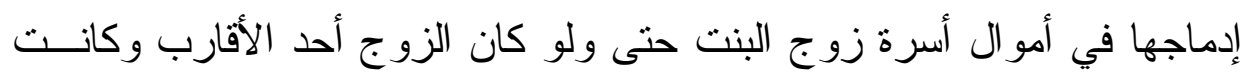

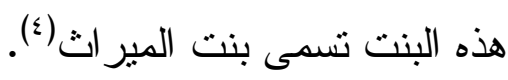
رابعًا: عند الرومانيين: يشتهر الرومان بأنهم قوم قانونيون بـــالفطرة، وجــاءت بعـض أحكــام المير اث عندهم مو افقة للصو اب منسقة مع العقل و المنطق، وجاء بعضها الآخـر مجانبًا للصو اب، مصنادمًا للعقل و المنطق.

ومن الأحكام المو افقة للصو اب، المتسقة مع العقل و المنطق و عدالة الفطرة

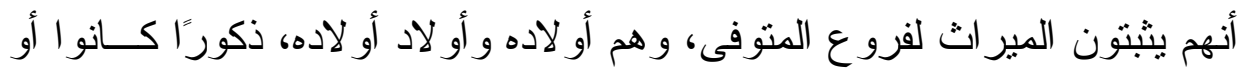
إناثا، ويستقل الفرع الوارث عندهم بالميراث، ويكون له الأولوية و التفضيل على

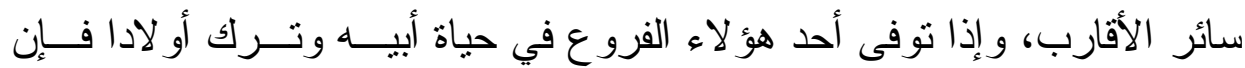
هؤلاء الأو لاد يحلون محل أبيهم في المير اث، ويأخذون النــصيب الــذي كــان

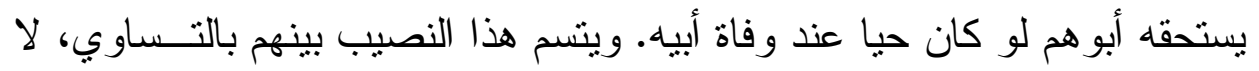

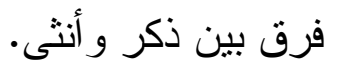

$$
\begin{aligned}
& \text { (§) المرجع السابق؛ د. فخري أبو سيف في أصول النظم القانونية والاجتماعيـة، صـهـ، } \\
& \text {.ro0 } \\
& \text { مجلتّ البحوث القانونيت والإقتصاديت }
\end{aligned}
$$


ويلي الفروع في الميراث أصول المتوفى وهم الآباء و الأمهات و الأجــداد

و الجدات، وهم لا يرثون إلا إذا انعدم الفروع، ويقدمون على من عـدـاهم مــن

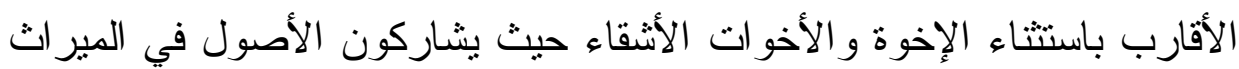
بالتساوي فيما بينهم، لا فرق بين ذكر و أنثى.

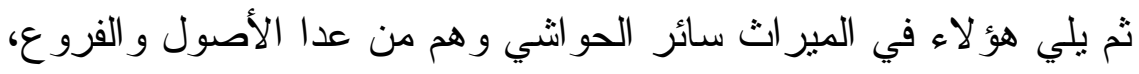

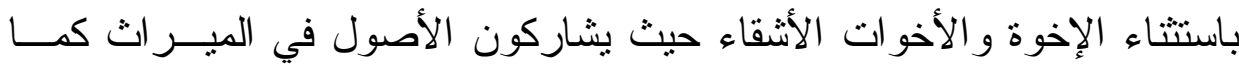

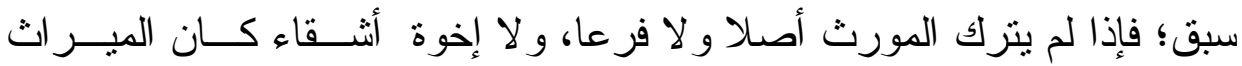
للأخوة و الأخو ات لأب، و إلا كان للأخوة والأخوات لأم لا فرق بين ذكر ولات ألنتى. هذا ولم تكن الزوجية عندهم سبيًا للمير اث، فلا الــزوج يـرث زوجتــهـ

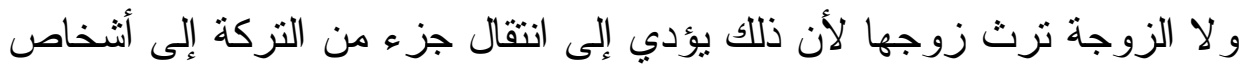
من خارج أسرة المتوفى، وفي هذا مجافاة للعدالة و الفطرة و العشرة. و إذا كان الرومان يسوون في المير اث بين الذكر و الأنثـى علــى النحسـو

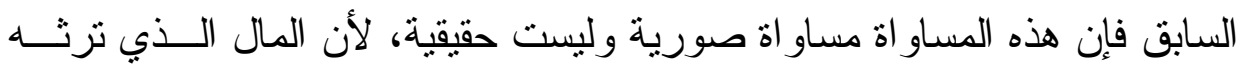

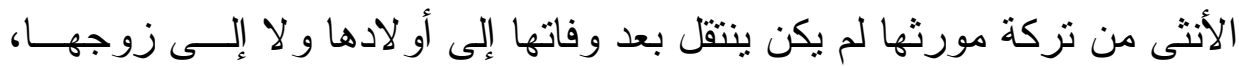

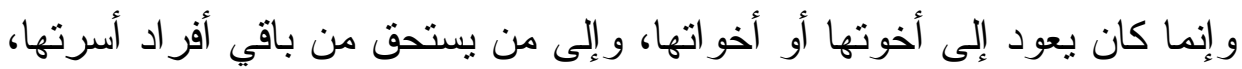

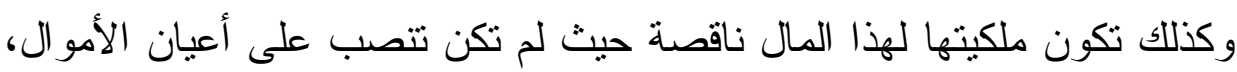
و إنما على مقامعها، ولم تكن تملك التصرف في أعبان هذه الأمو ال(ه).

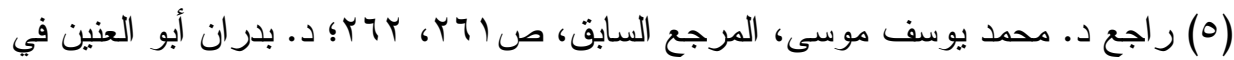

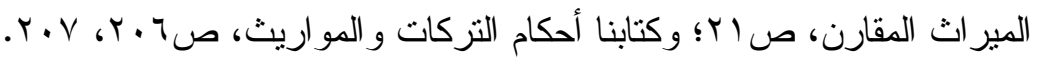


نظام الميراث عند اليهود يُحصر الميراث في الأسرة؛ منمنلة في البنــوة و الأبوة و الأخوة و العمومة، و أما الزوجية فهي سبب للمير اث من جهــة و احــدة، حيث يرث الزوج في نزكة زوجته إذا ماتت قبله و لا ترث الزوجة في زوجهـا

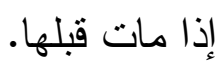

وميراث الأب يكون لأبنائه الذكور فقط دون الإناث، ويتميز الابن الأكبر بأن لله منل نصيب ابنين من أخوته الأصغر سنا منه، ما لم يكن هنــاك، اتفــاق بينهم على اقتسام التزركة بالتساوي. وهكذا فالبنات لا مير اث لهـنـ فــي تركــة أبيهم، وليس لهن سوى النفقة حتى تنزو ج الو احدة مــنهن أو تـصل إلــى ســن البلوغ.

ولا ترث الأم في ابنها و لا في ابنتها، و إذا ماتت كان مير اثها كله لابنهــا

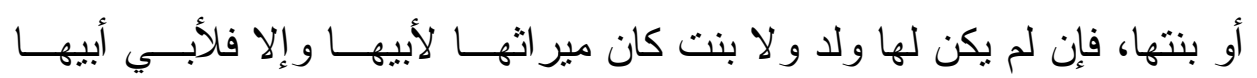
و إلا فلجد أبيها.

و إذا لم يكن للميت فروع و لا أصول، وكان لــهـ أقــارب مــن درجـات

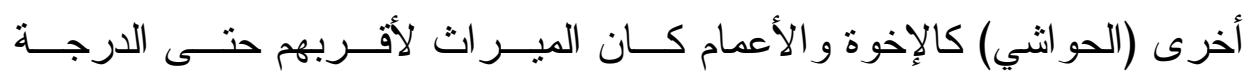
الخامسة، ثم تتساوى الدرجات بعد ذلك ويرث الكل بدون تمبيز و لا فــرق فــي

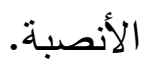




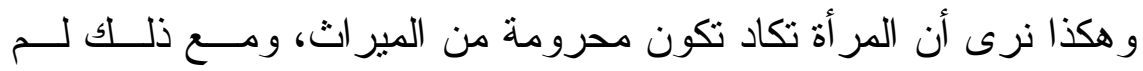
يتعرض أحد من المستثرقين المغرضين، و لا من المستغربين التابعين لمثل هذه ونه

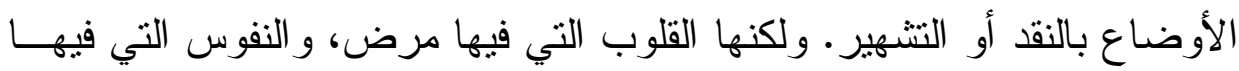

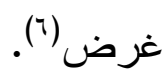

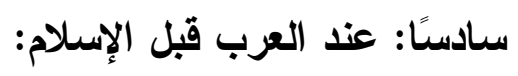

كان العرب قبل الإسلام يحصرون أسباب المير اث في ثلاثة هي: النسـسب و التبني و الحلف.

وكانو ا يقصرون المير اث بالنسب على الرجال المقاتلين الذين لهم القــدرة

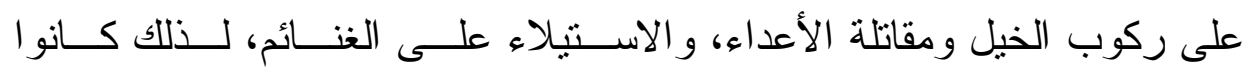

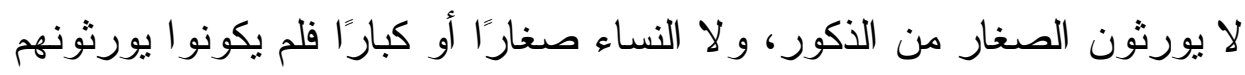

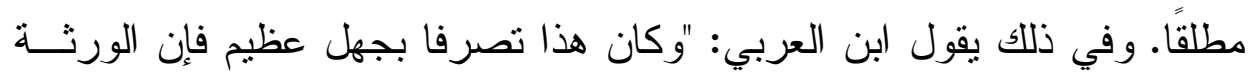

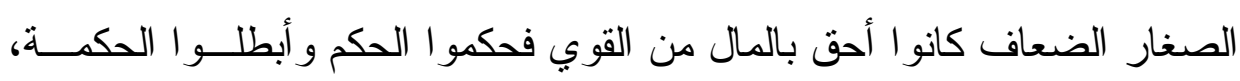

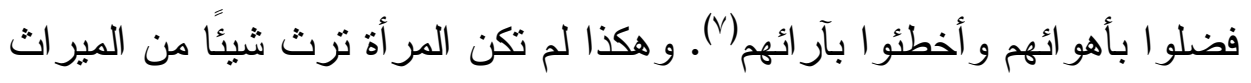

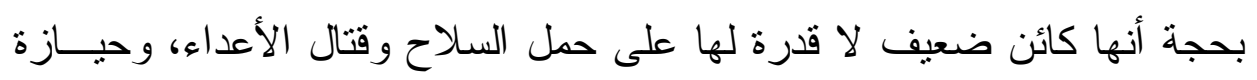
الغنائم.

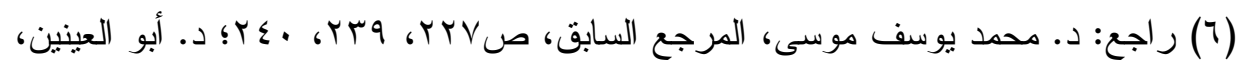

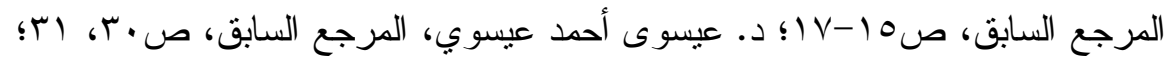

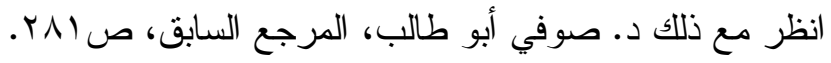

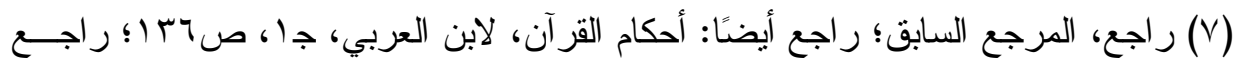

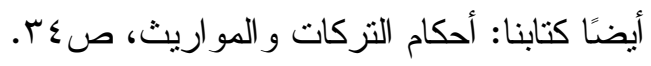


لم تخرج القوانين الغربية على أصولها التاريخية عند الرومان واليونــان التي يدور مير اث المر أة فيها بين الإفر اطو التقريط كما سبق أن بينا.

فالقانون الإنجليزي يقام الأبناء الذكور على البنــات مــن طبة ـتهم فــي المير اث، فالأبناء أولى من البنات في استحقاق المير اث مــن البنــات، و الابــنـ

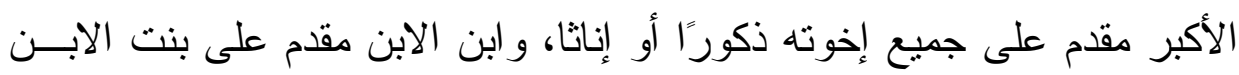
وبنت البنت وهكذا إلى أي حد يميز القانون الإنجليزي، الذكور على الإناث الذي

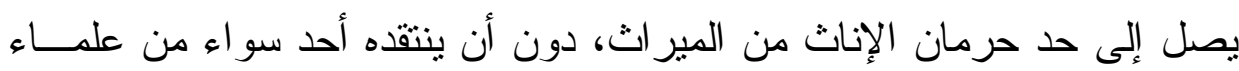
القانون الإنجليزي أو من غيرهم.

و وعلى الجانب الآخر نجد القانون الفرنسي والقانون الألماني، يسويان بين

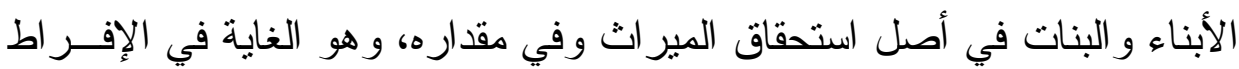

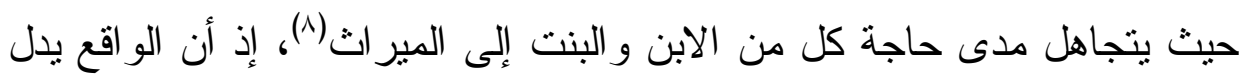

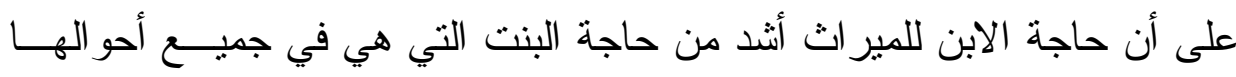
مكفية المؤنة بنتا في بيت أبيها وزوجة في بيت زوجها.

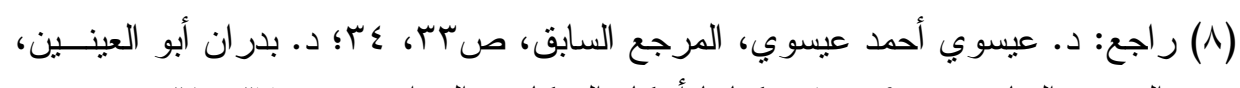

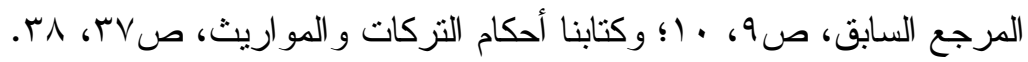

مجلتً البحوث القانونيتوالإقتصاديت 


\section{المحور الثاني}

\section{وضع المرأة في الإسلام بوجه عام \\ وعلى الأخص في الميراث}

لقد كانت المر أة قبل الإسلام كمًا مهملاً، ومطروحا في زوايــا النـسيان

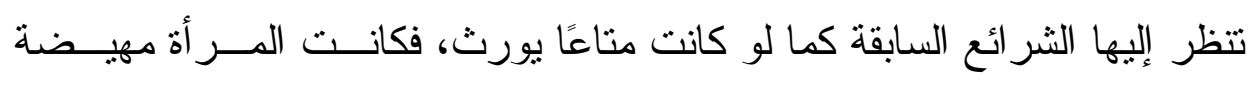

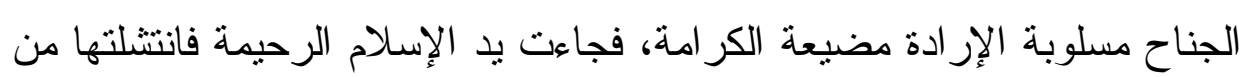

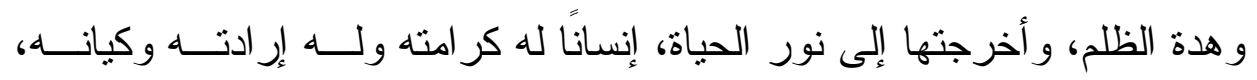

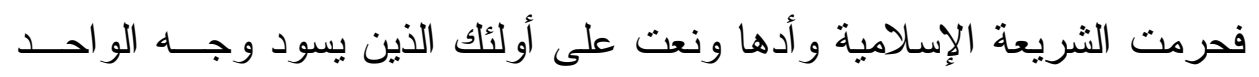

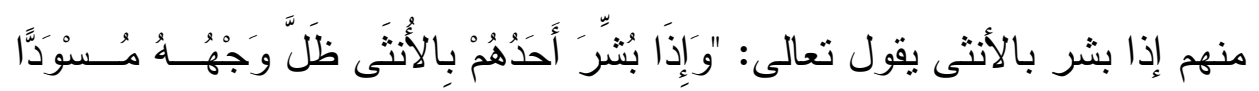

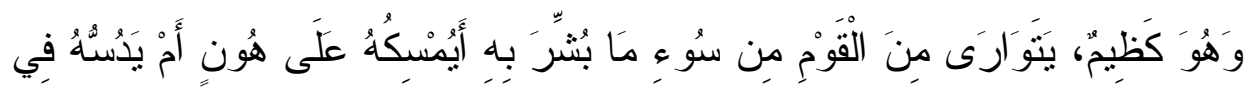

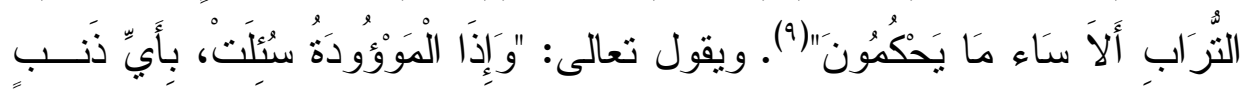

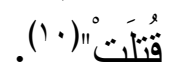

كما حرمت الثريعة العادات الجاهلية التي كانت تــس كراهـــة المـــرأة فحرمت أرث المر أة أو عضلها، فقد كان من عادات العرب في الجاهلية أنـــه إذا

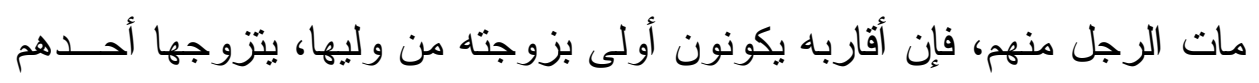

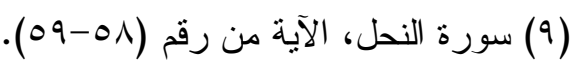

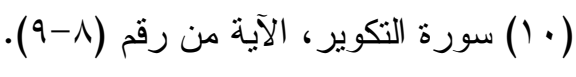

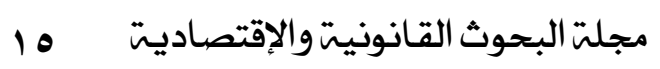




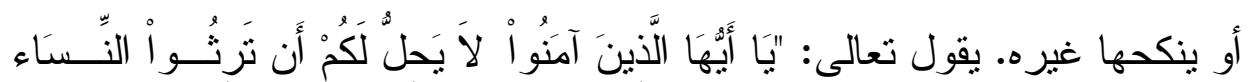

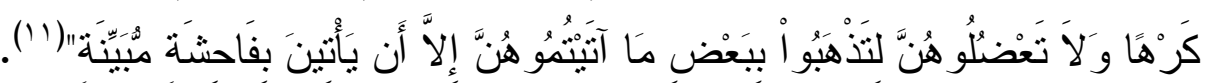

كذلك حرمت الثريعة الإسلامية أخذ شيء مما أعطى لها من مهر وغيره

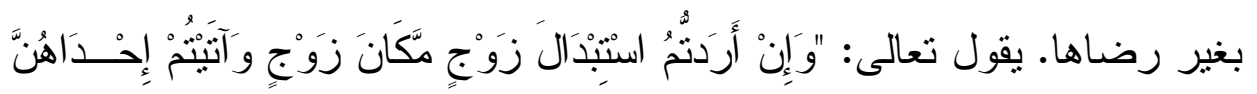

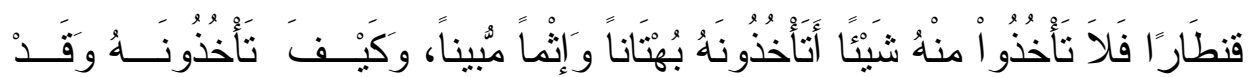

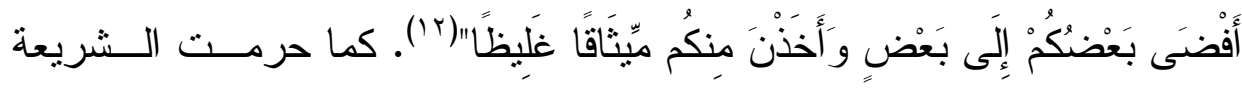

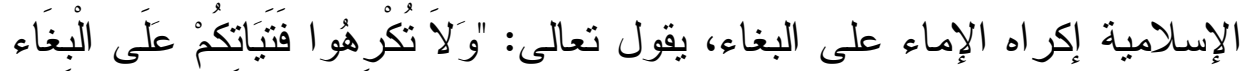

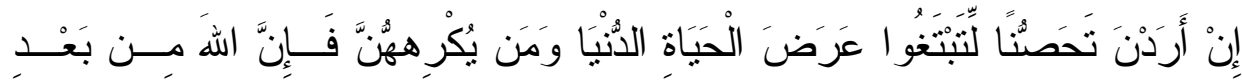

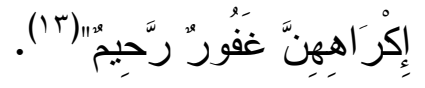

ثم تأتي التوصية بالنساء في أبلغ صورة، يقول صــلـى الله عليــهـ وســلم: "استوصو ا بالنساء خير ا، فإنما هن عندكم عوان، ليس تملكون منهن شيئًا غيــر

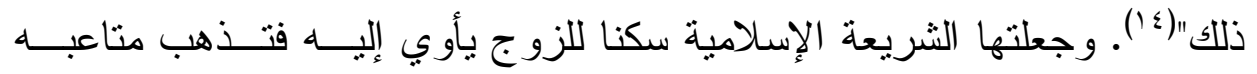
وتشاركه همومه، وربطتها بالرجل برباط المودة و الرحمة، يقول تعالى: "وَمَـنْ

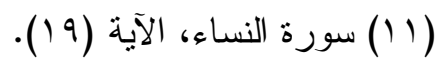

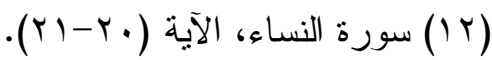

$$
\begin{aligned}
& \text { (T) سورة النور ، الآية (Tr). }
\end{aligned}
$$

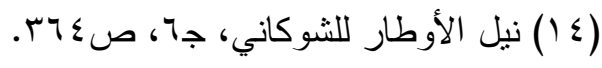




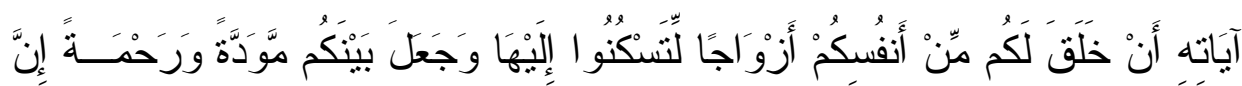

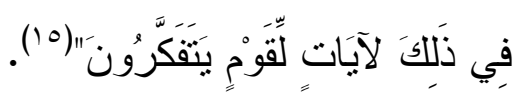

وأوجبت الثريعة على الرجل أن يعاثر امر أته بالمعروف، قال تعــلى:

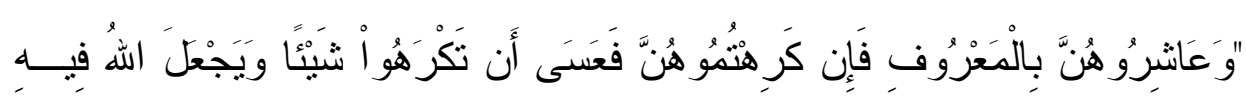

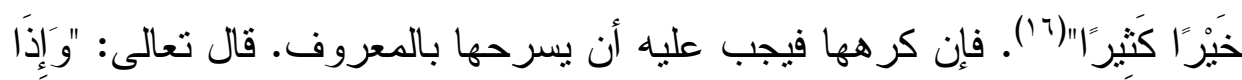

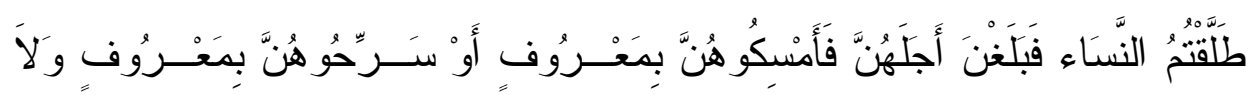

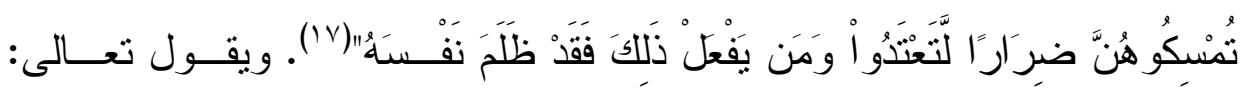

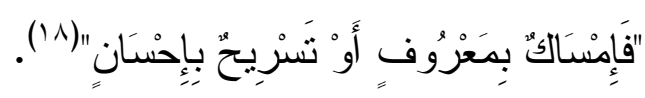

فهل بعد هذا الثكريم للمر أة من تكريم؟ وهل أخذت المر أة مكانها فـي أي من التثريعات قديمها وحديثها، كما هي في الثريعة الإنسامية. وفي هذا الإطار قد أعادت الثريعة الإسلامية للمر أة حقها المسلوب فـي

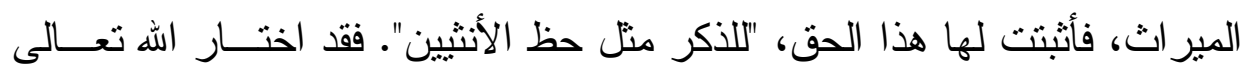

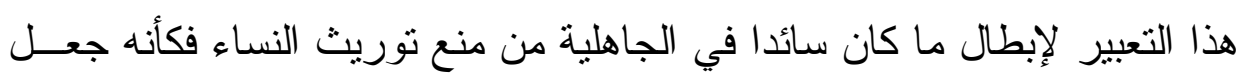

$$
\begin{aligned}
& \text { (10) سورة الروم، الآية، (Y) (Y). } \\
& \text { (17) سورة النساء، الآية (19). }
\end{aligned}
$$

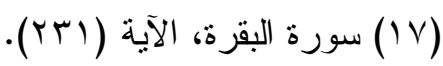

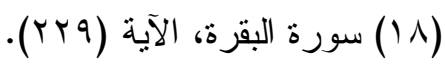

IV مجلت البحوث القانونيت والإقتصاديت 
أرث المر أة مقررًا معروفًا، أو كأنه جعل أرث المر أة هو الأصل وأرث الرجـل

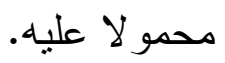

ولقد ورثت الثريعة الإسلامية الزوجة من زوجها لأنها نساوت معه فـي

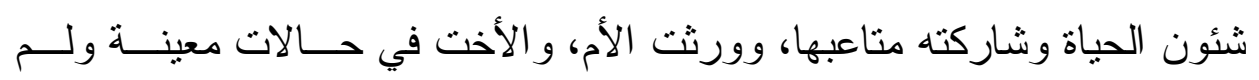
يحرم الأم من مير اثها بأي حال حتى مع وجود الأبناء.

و الثريعة الإسلامية حين أعطت المرأة حق الميراث جعلته على النصف من الرجل الذي يحاذيها في القرابة.

و الواقع أن الثريعة الإسلامية يجعلها ميراث المر أة على النـصف مــن الرجل تكون قد وضعت الأمر في نصابه على أساس من الحق و العدل و الحكمة

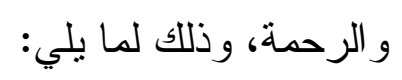

أولاً: أن ذلك يتقق ويتلاءم مع وظيفة كل منهما في الحياة، فالرجل يجب عليــه

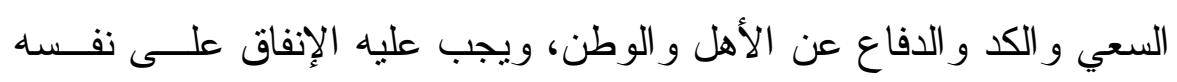
وزوجته و أو لاده و على من يحتاج من أقاربه، فهو راعي الأسرة وحاميهــا

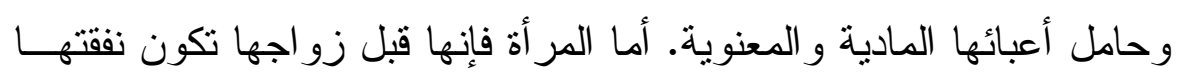
على أبيها أو أقرب الناس إليها إذا لم تكن ذات زوج، وإن كانت متزوجــة

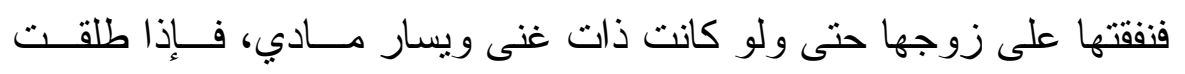


وجبت نفقتها على أوليائها، فهي في جميع أحو الها مكفيــة المؤنـــة رعايـــة لأنوثثها وحفظها لها، وتقديرًا لثرف وظيفتها في المجتمع.

ثانيًا: في تسوية المر أة بالرجل في المير اث إخلال بالبناء الاجتماعي وزعزعــة لأركان الأسرة، لأنها إذا تساوت بالرجل أدى ذلك إلى تفاقم الثزوة وتجمدها

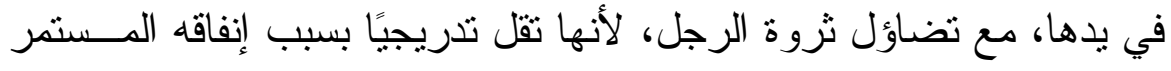

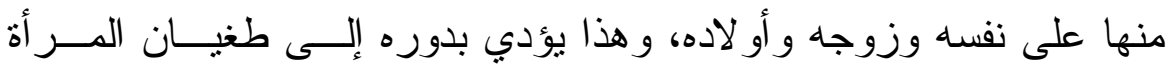

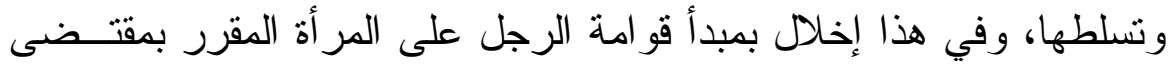

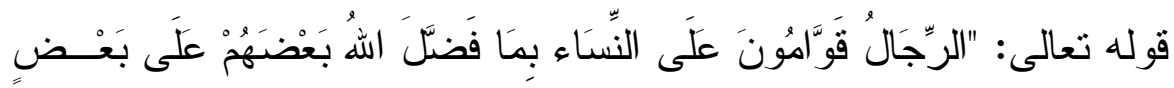

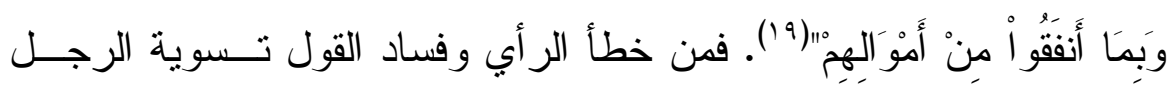
بالمر أة. إذ لا يعقل أن تسوى بالرجل ونطالبه بالإنفاق عليها.

ثالثًا: على أن الثريعة الإسلامية حين جعلت نصيب المر أة على النـصف مـن الرجل هو المبدأ الغالب عند التساوي في الدرجة، نجدها قد سوت بينهما في المير اث في الحالات التي تقتضي ذللك، فقد سوت الثريعة في المير اث بين الإخوة لأم ذكور ا وإناا، بناء على أن الصلة التي تجمع بينهم وبين المورث

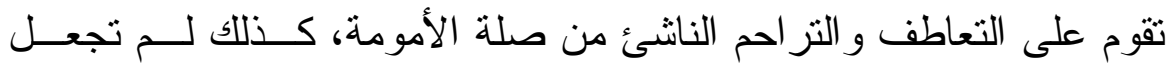
الثرعية الإسلامية للأب ضعف نصيب الأم، لأنه يفضل عليها بجمعه بــين 
الفرض و التعصب أحيانا، كذلك سوت الثريعة الإسلامية بــين الأم و الأب فيما لو توفى عن ابن أو ابن ابن، وأم وأب لأن صــلة الأمومســة و الأبــوة حينذالك لا تسنوجب إلا الثفقة و الرحمة.

وبعد هذا النموذج الر ائد في حماية المر أة وصيانة كر امتها ور عايتها فـي كل شئون حياتها، يخرج علينا أولئك الضالون المضلون، من حين لآخر بنغنتهم

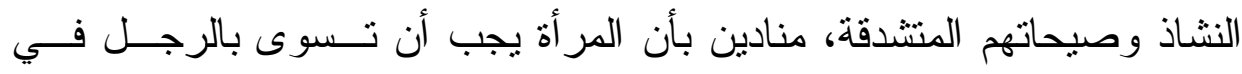
المير اث، نقول لهؤ لاء و أولئك: انقو ا الله واعرفو ا للكلمة حقها. فها هي المر أة في بي المجتمعات الغربية التي تزعمون تقدما وتطور ها ماز الت تقفقد أبسط حقوقهـا، فهي بمجرد زو اجها تفقد كثثرًا من شخصيتها وتفقد حقها في التصرف المسالي، وتفقد اسم أبيها وتكتسب اسم زوجها، و لاز الت المر أة هناك تكــافح مــن أجــل الحصول على قليل من كثير حصلت عليه المر أة المسلمة منذ ما يزيد عن أربعة

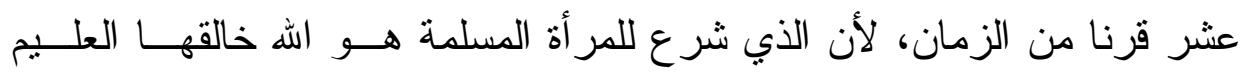

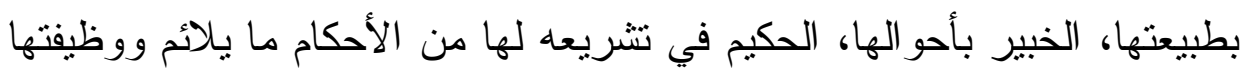
في هذه الحياة. 


\section{المحور الثالث}

\section{خصائص نظام الميراث في الإسلام}

\section{والأسس التي يقوم عليها}

يتيمز نظام المير اث في الإسلام بالعديد من الخصائص التي تميـزه عــن

غيره من نظم المير اث الأخرى سو اء أكانت وضعية أم سماوية، كما أنـــهـ يقــوم على العديد من الأسس و المبادئ و القو اعد الكفيلة بتحقيق العدالة المطلقـــة بــين الورثنة وفقا لقر ابتهم من المورث، ووفقا لمدى حاجتهم إلى المــال علــى نحــو دقيق، ولذا نجد في المسألة الواحدة من مسائل الميراث ورثنة من أقارب الميــت من أكثر من جهة، كأبيه و أمه وزوجته أو زوجه، و أبنائه وبناته، كل حسب قــوة قر ابته من المورث ومدى حاجته إلى المير اث. وذللك وفقا لما يلي: أولاً: خصائص نظام المير اث في الإسلام:

يتميز نظام المير اث في الثريعة الإسلامية بعدة خصائص تجعله نظامًا منميز ا وفريدًا، ورذه الخصائص هي: أولاً: أن اله تعالى قد تولى بنفسه تحديد المستحقين للميــر اث، وتفـرد بتوزيــع التركة عليهم ولم يترك ذلك لشخص صاحب المال، فليس لصاحب المال أن يعين الوارث من بعده، و لا أن يحدد نصيب كل وارث، بل إن ذلك كله مما 


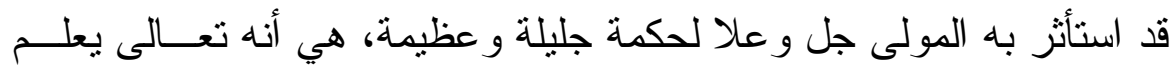
طبيعة الإنسان و أنه قد يغلب عليه الهوى، وتستبد بــهـ العاطفــة الجامحسـة، فيحرم بعض الورثة ويعطي للبعض الآخر ، أو يؤثر بعضهم بزيادة وهـــا

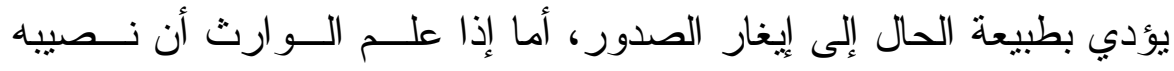

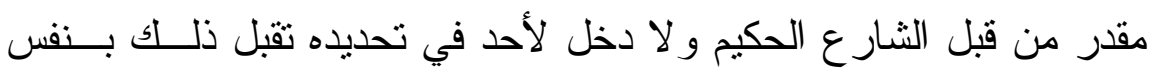
راضية وقلب مطمئن، إلى أن هذا هو حكم الله الذي لا يظلم أحسدًا، يقــول

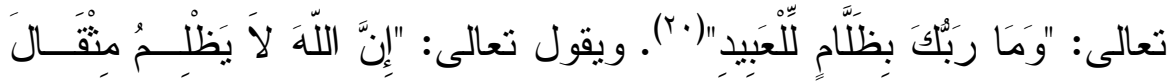

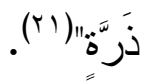

ثانيًا: لقد انتهجت الثريعة الإسلامية كما هو الثأن في كل تـشريعاتها منهجــا

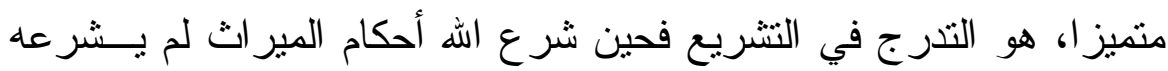
جملة واحدة، ولم تتزل آيات الميراث التفصيلية دفعة واحدة و إنما نزلت بعد

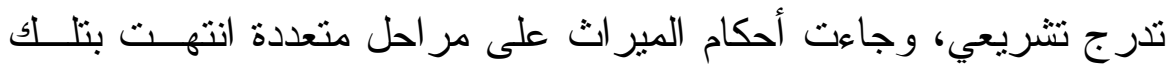
الآيات التي بينت المستحقين للتركة ونصيب كل و ارث.

و الحكمة في ذلك تبدو و اضحة جلية إذ أن النفس البشرية بطبيعتها تميـلـ إلى التمسك بما ألفته من عادات موروثة، وقد ألف العرب كما علمنــا عــادات 
وتقاليد فيما يتعلق بالمير اث وحتى يسهل تخليصهم من تلأك العادات التي كانـــ

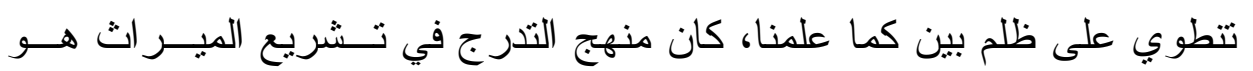

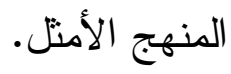

\section{هذا ولقد مر تثريع الميراث بالمراحل الآتية:}

1- حين جاء الإسلام لم يشأ مصادمة ما كان عليه العرب في الجاهلية فأبقى كل شيء على ما هو عليه، ريثما تتشرب النفــوس مبــادئ الإســـلام القويمـــة

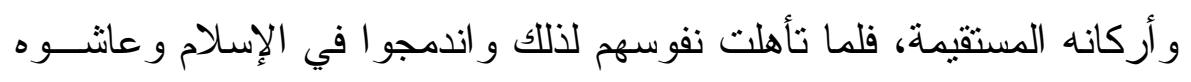
سلوكا وو اقعا انطلاقا من وحي عقيدة التوحيد التي بدأت تتغلغل في نفوسهم

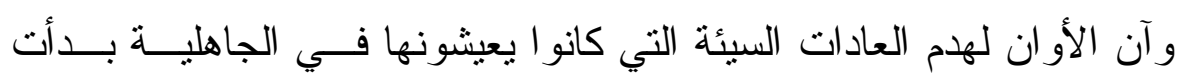
مر احل التشريع العملي.

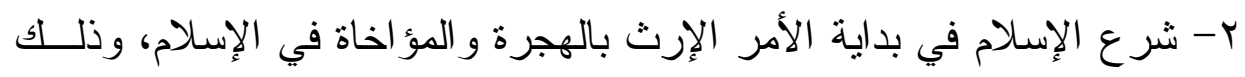

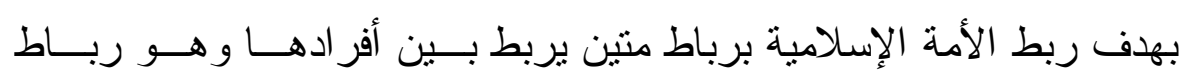

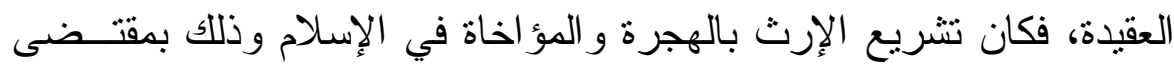

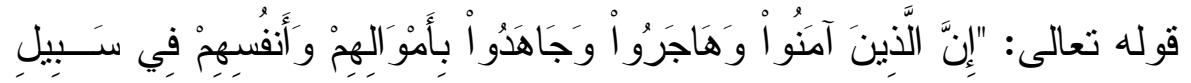

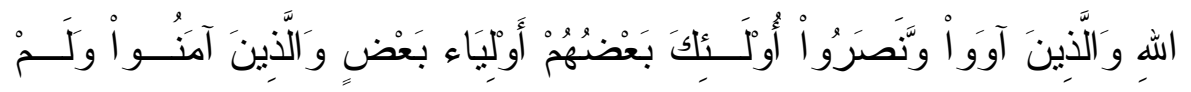

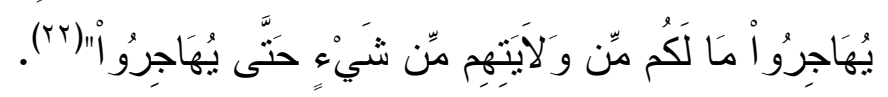

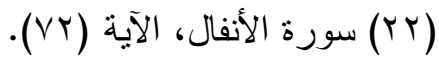

مجلت البحوث القانونيت والإقتصاديت 
فالمقصود بالو لاية في الآية ولاية الإرث التي سبيها القرابة الحكميــة بـين المهاجرين و الأنصار، ولقد استمر النوارث بالهجرة إلى أن أعز الله الإسلام

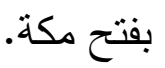

r- أبطل اله تعالى عادة التنبي التي كانت معروفة لاى أهل الجاهلية بمقتـ ضى

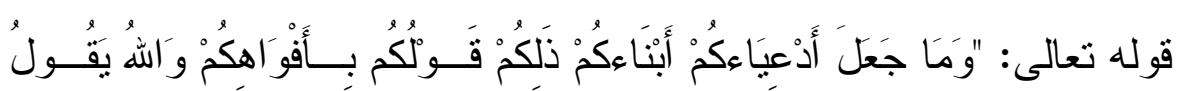

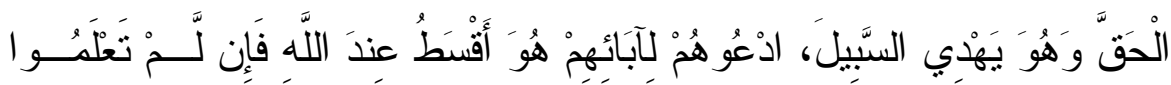

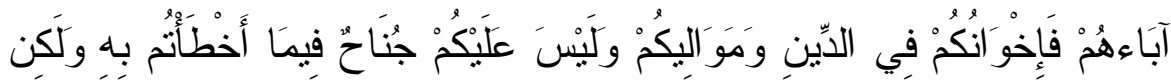

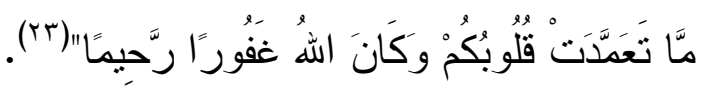
وبإبطال الإسلام للتبني، أبطل جميع آثارهو أهمها المير اث بالتنبني. ع - بالنسبة للمير اث بالحلف و المعاقدة، ذهب جمهور الفقهاء إلى أنه نسخ بآيـات المواريث، وذهب الحنفية و الثيعة الإمامية إلى أنه لم ينسخ و إنما آخر فـي الترتيب عن مير اث ذوي الأرحام.

0- خطأ الإسلام خطوة أخرى في تشريع المير اث ، فأوجب على الـشخص أن

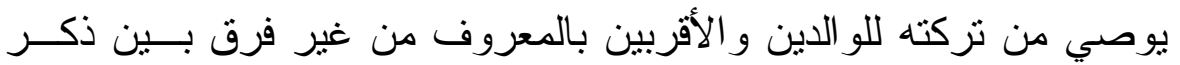

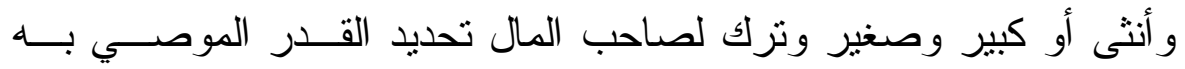


للو الدين و الأقربين، ولكنه وضع له إطارًا من العدل يتصرف مــن خلالــهـ،

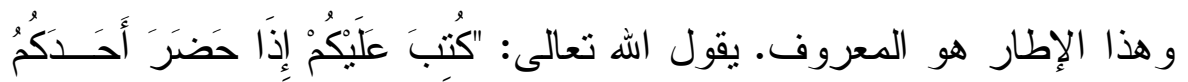

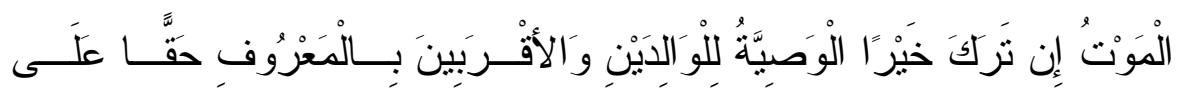

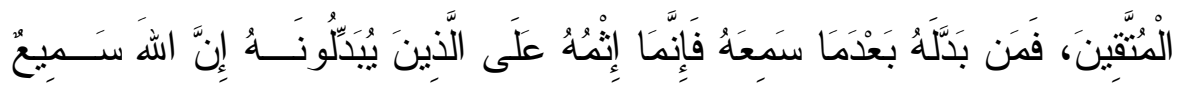

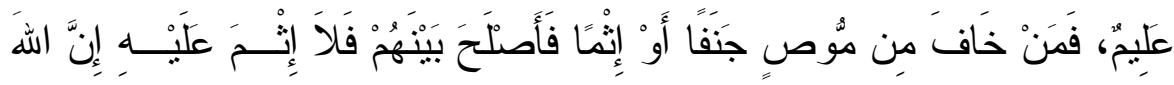

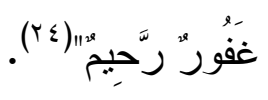

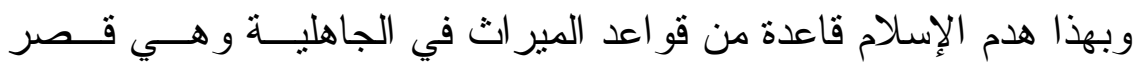

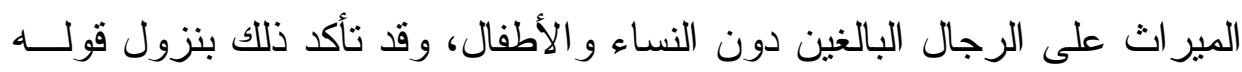

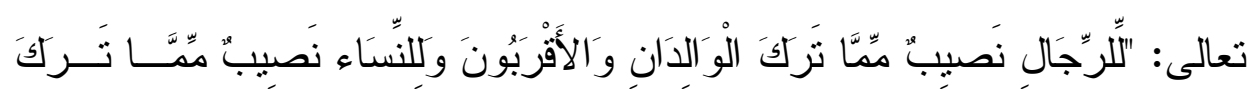

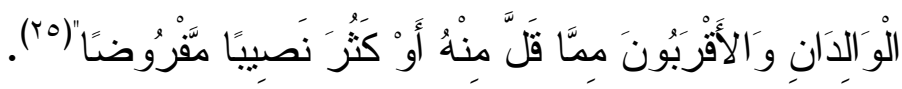

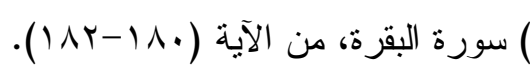

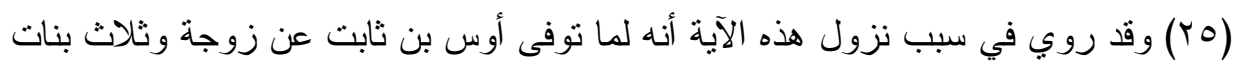

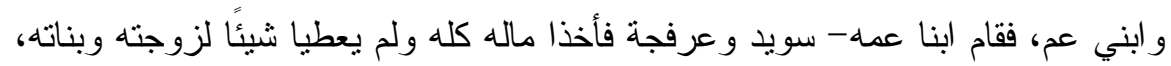

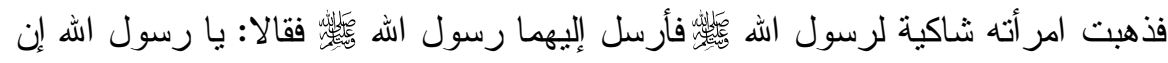

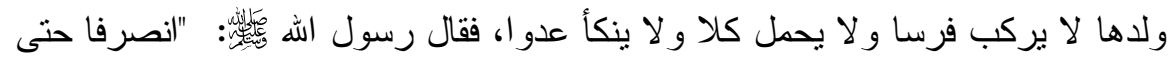

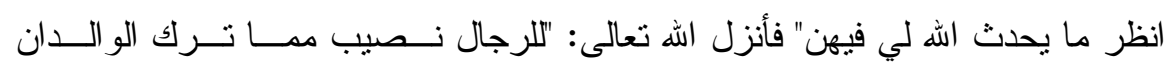

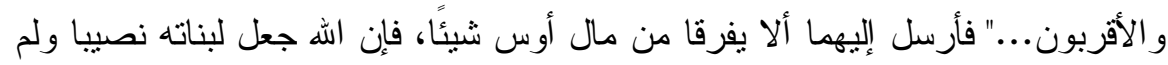

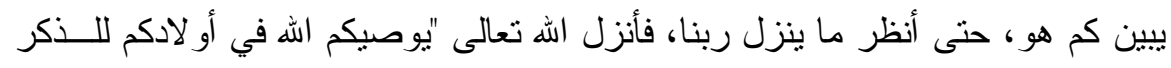

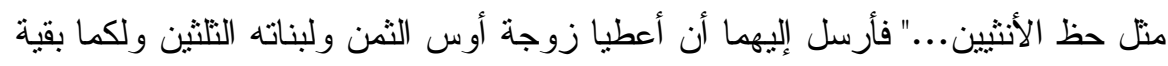

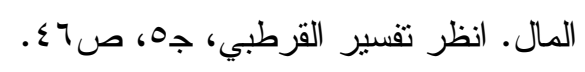

مجلة البحوث القانونيت والإقتصاديتة 
وقد جاءت هذه الآية مجملة لم تورد تفصيلا للمستحقين و لا أنـصبائهم

و الحكمة في ذلك تهيئة الأذهان و العقول لما سينزل بعد ذلك من تفـصيل لهـذا

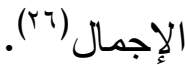

؟- الخطوة الأخيرة من خطوات التندرج في تشريع المير اث هي نــزول آيــات المو اريث المفصلة لأحكامه و المبينة للمستحقين للتركة، و أنصبائهم وشـروط استحقاق كل وارث لنصيبه في التركة وحالات كل وارث وهي قوله تعالى:

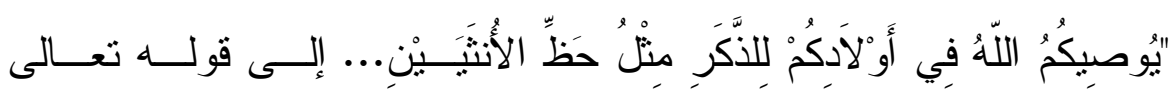

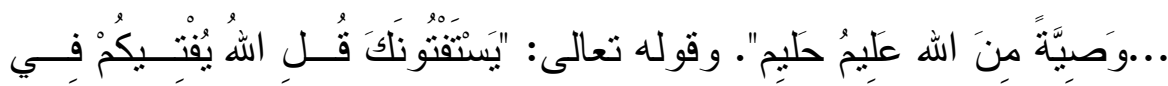

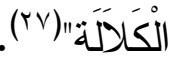

ومن الجدير بالذكر هنا الإثشارة إلى أن الله تعالى بعــــ أن أنـزل آيــات

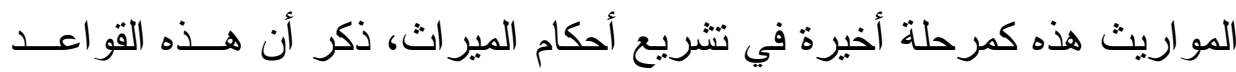
وتلاك الأحكام إنما هي حدود الله التي حددها و أحكامه التي شرعها، فمن أطـــاع الله تعالى في تتفيذ هذه الأحكام و الالتز ام بهذه الحدود كان جزاؤه فـــي الآخــرة الفوز العظيم و الخلد في جنات تجري من تحتها الأنهار ، ومن عـصى وخـــرج على هذه الحدود وتعداها كان جز اؤه في الآخرة عذابا مهينا وخلدا في نار جهنم 


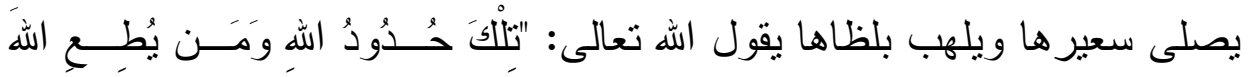

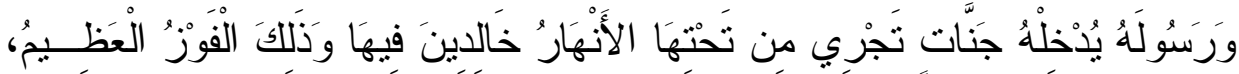

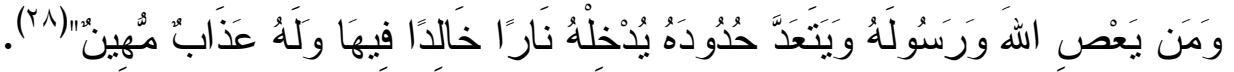
ثالثًا: الخاصية الثالثة من خصائص نظــام الميــراث الإســلامي: أن الــشريعة الإسلامية قد جعلت نظام الأرث نظاما إجباريا ســــاء بالنـسبة للـــورث

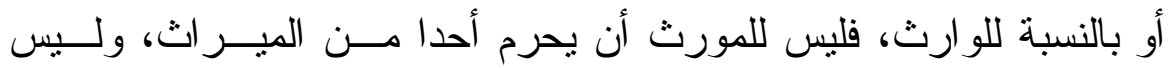

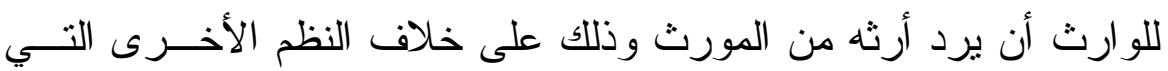
تجعل حق الأرث اختياريا.

رابعًا: عملت الثريعة الإسلامية على حفظ حق الورثة في حياة صاحب الـــال فقررت نعلق حق الورثة بمال المورث بمجـرد مــرض المــوت، فلـيس لصاحب المال أن يتصرف في مرض موته تصرفا ضارًا بالورثة أو يضيع عليهم حقوقهم.

غير أن الثشارع الحكيم لم يحرم صاحب المال من التصرف في جزء من

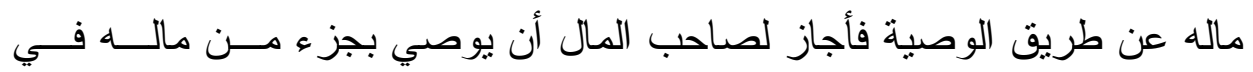

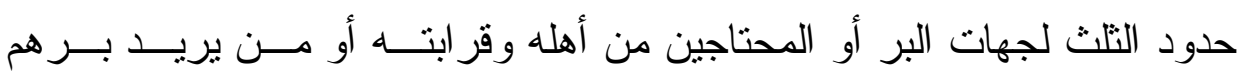
وصلتهم بعد وفاته بشروط معينة، فقد روي الجماعة عن سعد بن أبي وقاص أنه 


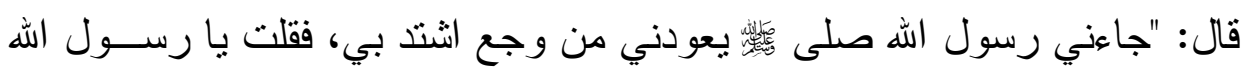
إني قد بلغ بي الوجع ما ترى و أنا ذو مال و لا يرثني إلا ابنة لي أفأتصدق بنتلثي مالي: قال: لا، قال: فالشطر يا رسول الله قال: لا، قلت: فالتلث؟ قال: النتــث، و التلث كثير أو كبير إنك إن تذر ورثتك أغنياء خير من أن تدعهم عالة يتكففون

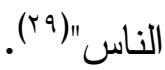

خامسًا: جعلت الثريعة الإسلامية تركة الميت لأحب الناس إليه و أكثرهم صــلة

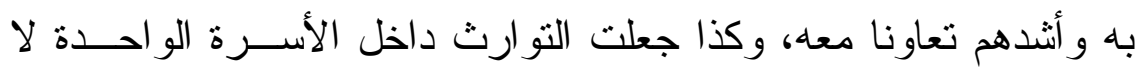
يتعدها، وفي هذا إصلاح للأسرة وتقوية للرو ابط بين أفر ادها.

سادسًا: نظام المير اث في الثريعة الإسلامية يحول دون تجمع الثزوة فــي يـــ و احدة على حساب الآخرين، ويؤدي إلى تفتيت الثروة وتوزيعهــا علــى أكبر عدد من المستحقين للتركة، فيعم نفعها أكبر عدد من النسا ويفيد من

$$
\text { خير ها طائفة كبيرة من أقارب الميت. }
$$

سابعًا: جعلت الثريعة أساس تقديم بعض الورثة على بعض هو قـــوة القر ابـــة وشدة الصلة بالميت و اتصـال المنافع بين الوارث و المورث، ولـــللك قــدم

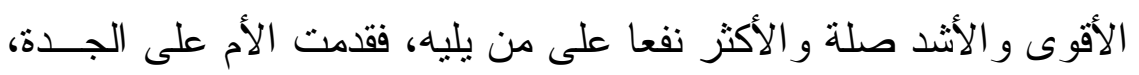

$$
\text { و الأب على الجد، و الابن على الأخ...وهكذا. }
$$


ثامنًا: حرصت الثريعة الإسلامية على حماية المستضعفين من النساء و الأطفال و أحاطتهم بالعناية و الرعاية، فجعلت للمر أة نصيبا من المير اث سو اء كانت

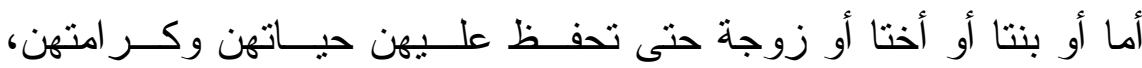
وتصون عليهم حياءهن وعفافهن، وجعلت للطفل الصغير حتى ولو كــان جنينا في بطن أمه نصيبا من الميراث، ولم تميز الابن الأكبر على أخوتــه. كما كان معروفا في الشر ائع السابقة.

تاسعًا: جعلت الثريعة الإسلامية الحاجة هي أساس التفاضل في المير اث ولهــذا جعلن نصيب البنت نصف نصيب أخيها الذكر، لأن حاجته إلى المال أثــــ من حاجتها إليه، كما أن مطالب الحياة وتبعاتها بالنسبة إليـــه أكتــر منهــــا بالنسبة للبنت، وجعلت نصيب الابن أكثر مـن نــصيب الأب، لأن الابــن يستقبل الحياة، فهو أحوج إلى المال من الجد- أبي الميت- الذي أوشك أن

$$
\text { يودع الحياة(·r) و هكذا. }
$$

هذه هي أهم خصائص نظام المير اث في الشريعة الإسلامية طهر لنا مــن عرضها أنها تقوم على أسـاس مــن العــدل و الحــق و الرحمــة، وأن التـشريع الإسلامي فيما يتعلق بالمير اث ينفرد بهذه الخصائص التي لــــت تجتـــع فـي أي تشريع آخر سو اء كان هذا التشريع سماويا أم وضعيا.

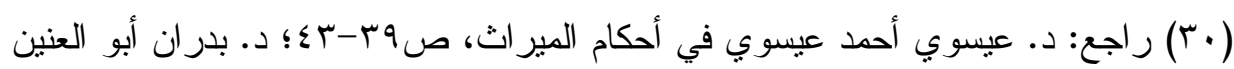

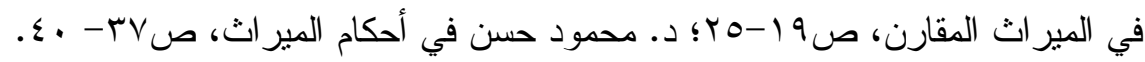


ثانيًا: الأسس و القو اعد لتي يقوم عليها نظام الميراث الإسلامي

يمكن القول بأن الأسس التي يقوم عليها استحقاق المير اث فـــي الـــريعة الإسلامية ترجع إلى ما يلي:

1- القرابة والزوجية: أما القر ابة فتشمل الأبناء و الآباء و الأخوة و الأعمام سو اء

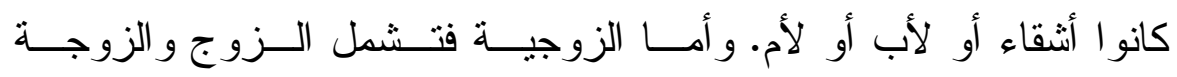

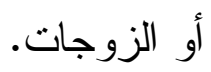

ץ- إلغاء صفات الذكورة و الأنوثة و الصغر و الكبر في أصل استحقاق الميــراث فلا فرق بين صغير وكبير و لا بين ذكر و أنثى، كما سبق.

r- الأصول و الفروع "الآباء و الأبناء" لا يسقطون في أصل الانــتحقاق بـأي

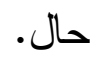

؟- عند اجتماع ذكور و إناث، فإن الذكر يأخذ ضعف الأثنى فيما عـــا الإخــوة

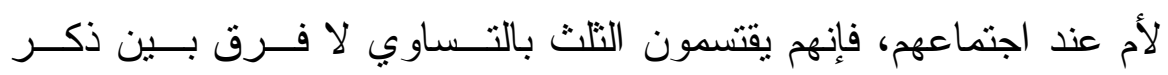

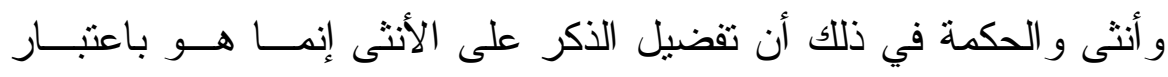

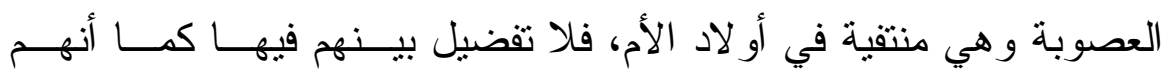

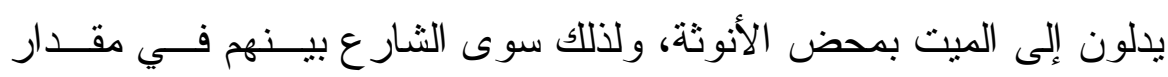
الاستحقاق.

r مجلتة البحوث القانونيت والإقتصاديت 
0- لا مير اث للأخوة مع وجود الأصل الوارث أو الفرع الوارث المذكر. هذا و إن قيام المير اث على هذه المبادئ وتلك الأسس يحيط به سياج مـن القو اعد النبيلة و التي تتمنل في الحب و العشرة و النصرة و العطف.

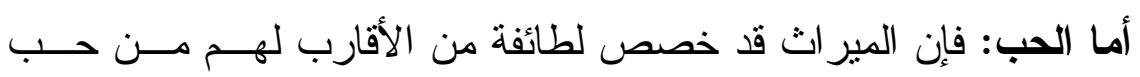

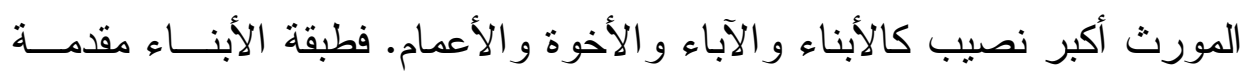

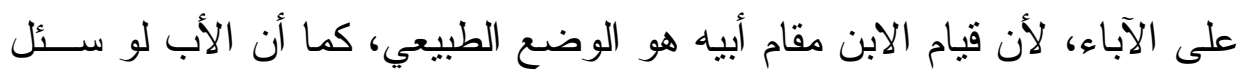

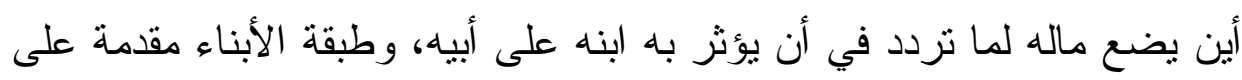

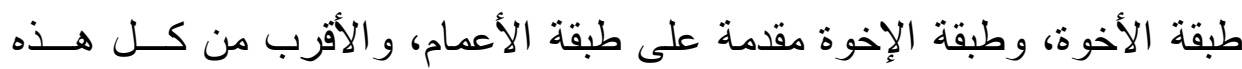
الطبقات مقدم على الذي يليه. وأما العشرة: فإن الإسلام وفاء منه لمن بصاحبون الميث أطول فترة من الزمن يشاركونه آلام الحياة وآمالها، أقر توريثهم وجعل لهم نصيبا من الميراث، لهئ فأقر الإسلام توريث الزوجة من زوجها و الزوج من زوجته.

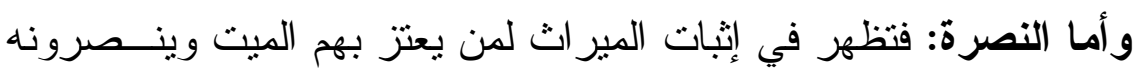
ويؤازرونه في حياته ويؤثرون الدفاع عنه، فكان ميــراث العـــبات النـسبية و السببية. و هكذا نجد نظام الميراث يقوم على أسس متينة، وقو اعد محكمة وير اعى فيها الحق و العدل و الرحمة و لا عجب، فهو ليس تشريع بشر و إنما هـو تـشـريع

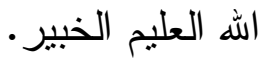

مجلت البحوث القانونيت والإقتصاديت 



\section{المحور الر ابع}

\section{أحوال ميراث المرأة في نظام الميراث الإسلامي}

قبل أن نبين أحوال المر أة في الميراث بوجه عام ننوه إلى أن الميراث فـي الإسلام قد يكون مير اثا بالفرض وقد يكون مير الثًا بالتعصيب.

فالمير اث بالفرض: هو مير اث سهم مقدر في التركة بمقتــى الكتــاب

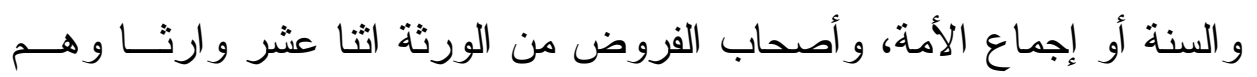

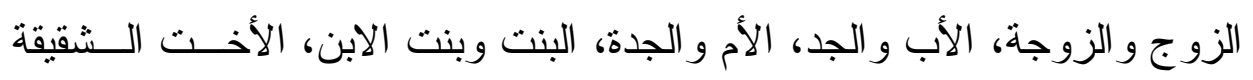

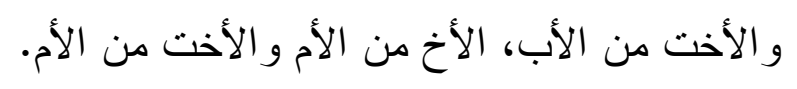

ويُلاحظ أن النساء من أصحاب الفروض ثمانيــة هــنـ: الأم و الجـــة،

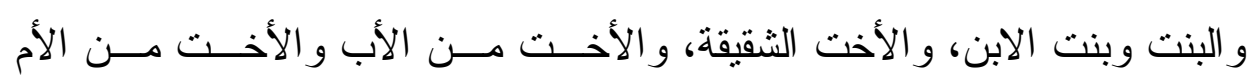

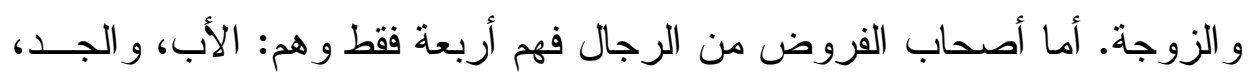

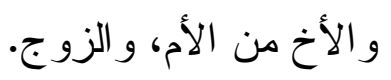
و أما الميراث بالتعصيب: فهو ميراث الباقي من التركة بعـــ أصــاب التهاب

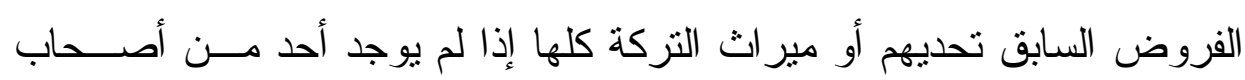

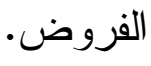


ويُلاحظ أن من النساء أصحاب الفروض، صنف يـصير عـصبة مــع

الذكر الذي هو في درجتها كالبنت مع الابن، وبنت الابن مع ابن الابن و الأخــت

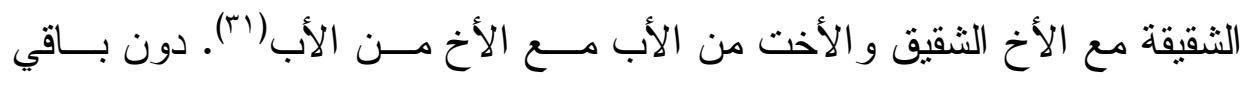

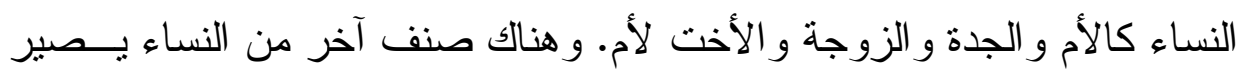

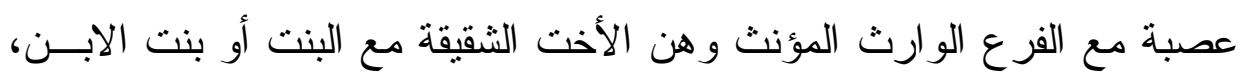
و الأخت من الأب مع البنت أو بنت الابن(rr).

و هكذا نرى أن المرأة تعتبر قدرًا مشتركا في كلا النوعين من الميراث، فهي قد ترث بالفرض، وقد ترث بالتعصيب، وفي كل حال تحصل على النصيب الذي ينو افق مع حاجتها، ومدى قوة قر ابتها من المورث حسبما ســنرى فـي

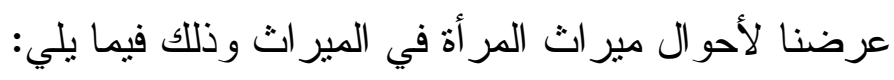

المر أة كما تبين لنا مما سبق قد تكون أمًا أو جدة، أو بنتًا أو بنـــت ابــن

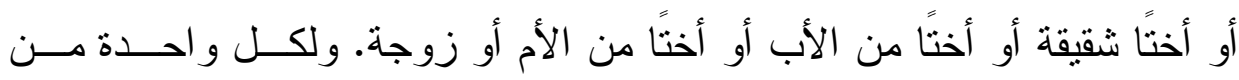

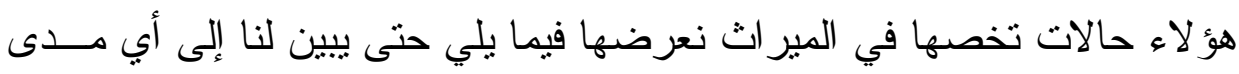
حرص الإسلام على ميراث المر أة.

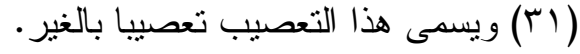

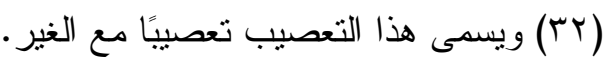

مجلت البحوث القانونيت والإقتصاديت س 


$$
\begin{aligned}
& \text { أولاً: أحوال الأم في الميراث: } \\
& \text { للأم في المير اث ثلاث حالات: }
\end{aligned}
$$

الحالة الأولى: ترث الثلث فرضا وذلك بشرطين:

أولهما: عدم وجود الفرع الوارث بالفرض أو التعصبب، كالابن وابـن الابــن،

$$
\text { و البنت وبنت الابن و إن نزل. }
$$

ثانيهما: عدم وجود اثثين فأكثر من الإخوة والأخوات من أي جهـــة كــانو ا، أي سو اء كانو ا أثنقاء أو لأب فقط أو لأم فقط، وسو اء كانو ا ذكور ا فقـ أو أو إناثا فقط أو ذكورًا و إناثًا.

$$
\text { فإذا توفى عن أب و أم كان للأم الثلث وللأب الباقي تعصيبا. }
$$

و إذا توفى عن زوجة وأخ شقيق وأم كان للزوجة الربع لعدم وجود الفرع الو ارث وللأم التثلث لعدم وجود الفرع الوارث أيضًا، ولعدم وجود اثثين فصاعدا من الإخوة و الأخوات، و الأخ الثقيق الباقي تعصيبًا.

و إذا توفى عن زوجة وأم و ابن بنت وأخ لأب كان للزوجة الربع فرضـــا لعدم وجود الفرع الوارث وللأم الثلث لعدم وجود الفرع الوارث ولعـدم وجــود عدد من الإخوة و الأخوات وللأخ لأب الباقي تعصبيا ولا شــيء لابــن البنــــ بالمبر اث لأنه من ذوي الأرحام و إن كان يستحق وصية و اجبة. ويلاحظ أنه لــــ 


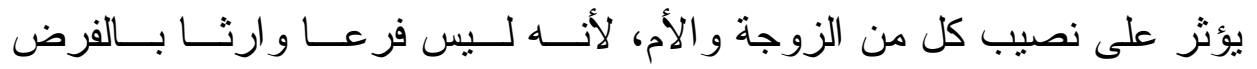
أو التعصبب.

و الدليل على فرض الأم في هذه الحالة. هو قوله تعالى : "فَإِنَ لَّمْ يَكُن لََّّهُ

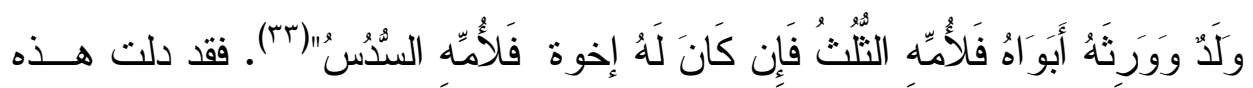
الآية على أن الأم تستحق تلث التركة إذا لم يكن للميت ولد وهو الفرع الــوارث ذكر ا كان أو أنثى، وكذللك عند عدم وجود الإخوة و الأخوات من أي جهة كانو ا.

\section{الحالة الثانية: ترث السدس فرضا وذلك في صورتين:}

أولاهما: إذا كان للميت فرع وارث بطريق الفرض أو التعصيب كــالابن و ابـنـ الابن و إن نزل، و البنت وبنت الابن و إن نزل.

ثانيتهما: إذا كان للميت اثثان فأكثر من الإخوة و الأخوات سو اء كــانو أثثـقاء أو للأب فقط أو للأم فقط، وسو اء كانو ا ذكور ا أو إناتا أو مختلطين.

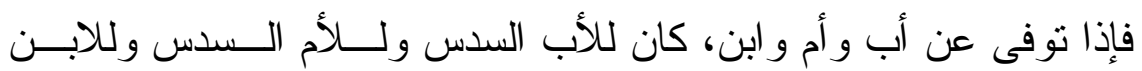
الباقي تعصيبا. و إذا نوفى عن أب و أم و أخويت شقيقين أو لأب أو لأم، كان للأم

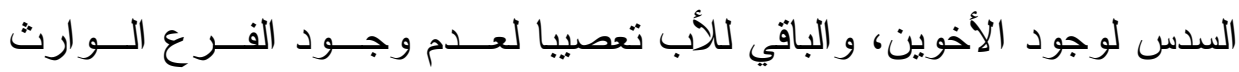

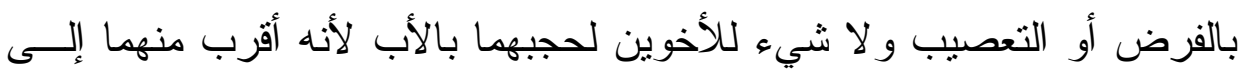

(1) (r) سورة النساء، الآية (1).

مجلتّ البحوث القانونيت والإقتصاديت 
الميت. بلاحظ هنا أن الإخوة والأخوات يحجبون الأم من التلث إلى السدس حتى

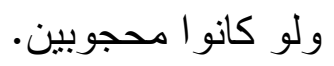

و الدليل على استحقاق الأم للسدس مع وجود الفرع الوارث ذكــرًا كــان

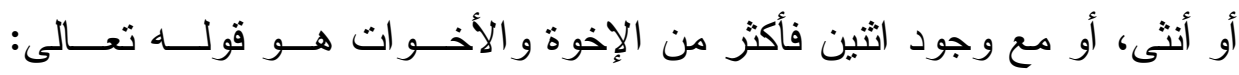

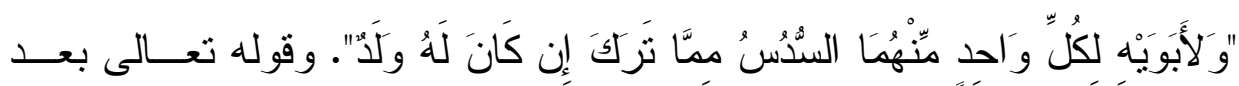

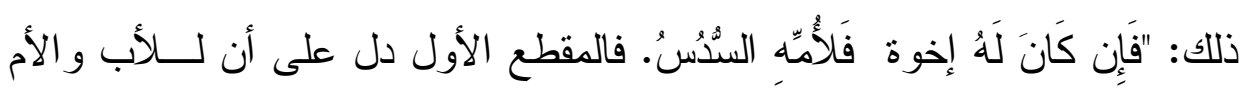

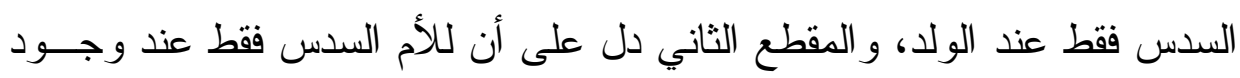
عدد من الإخوة وهو لفظ عام يشمل الذكور و الإناث كما يشمل الإخوة الأثــقاء

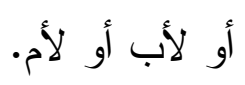

هذا ومذهب جمهور الفقهاءو هو ما قال به جمهور الصحابة أيضًا وهــو الراجح أن العدد من الإخوة والأخوات الذي يحجب الأم من التلث إلى الــسدس

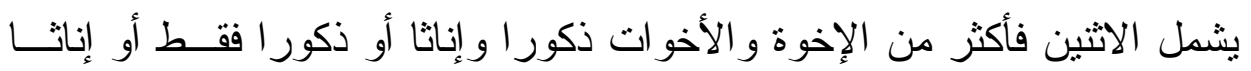
فقط. ولم يخالف في ذلك إلا ابن عباس، حيث يرى أن الإخوة الذين يحجبــون الأم من التلث إلى السدس هم الأكثر من اثثين. 


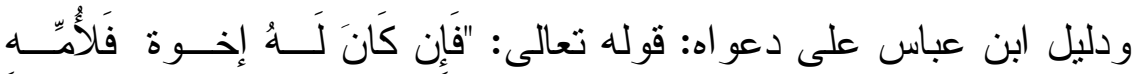

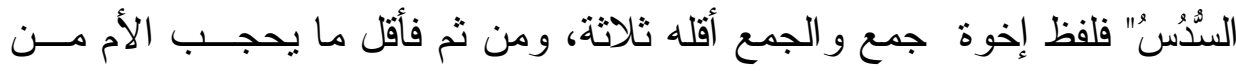
التلث إلى السدس ثلاثة من الإخوة و الأخو ات فأكثر ، و لا تحجب بالاثثين.

ويروى أن ابن عباس دخل على عثمان بن عفان فقال له: "إن الأخوين لا

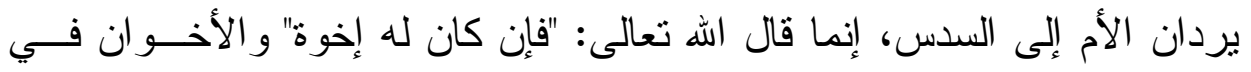

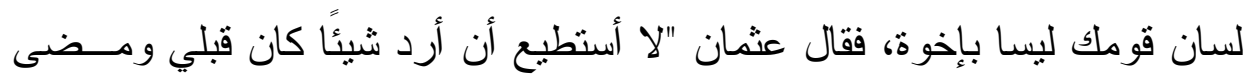

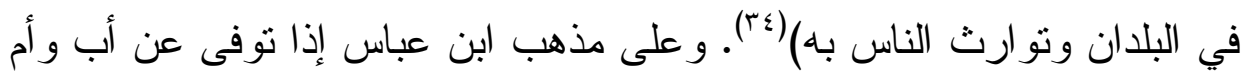

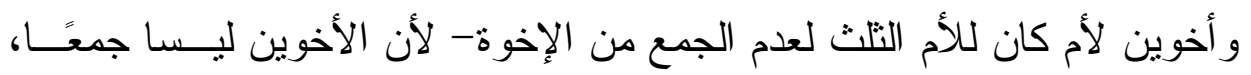
وللأب الباقي تعصييا لحجبهما بالأب.

أما جمهور الفقهاء فقد استدلو ا على أن المر اد بــالإخوة الاثتـين فــــثر

$$
\text { بما يلي: }
$$

1 قول عثمان بن عفان في رده على ابن عباس، فإنه يـــل علــى أن هنــاك إجماعا على ذلك تم قبل مخالفة ابن عباس.

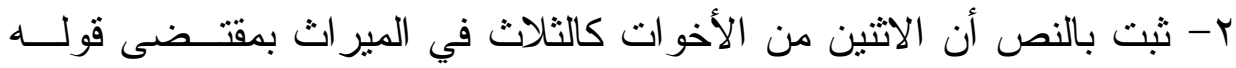

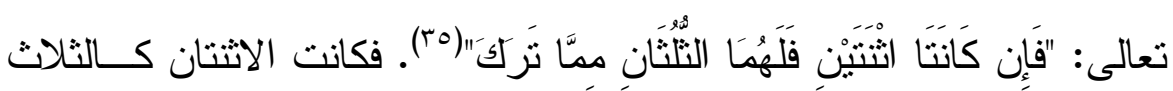
في الحجب.

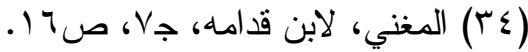

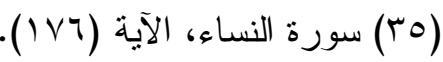

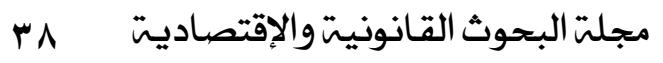


r- و أيضًا فإن كل حجب يتعلق بعدد كان أوله اثثين كحجب البنات بنات الابــن

$$
\text { وكحجب الأخوات لأبوين، الأخوات لأب و هكذا.. }
$$

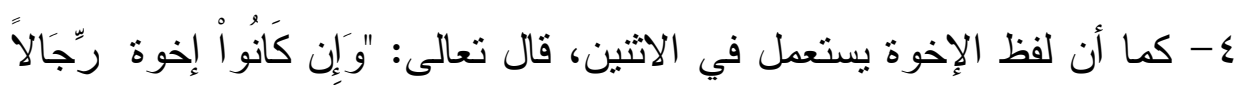

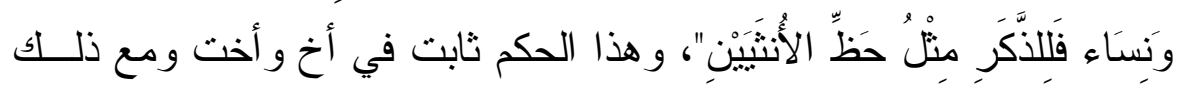

$$
\text { أطلق عليهما القر آن لفظ إخوة . }
$$

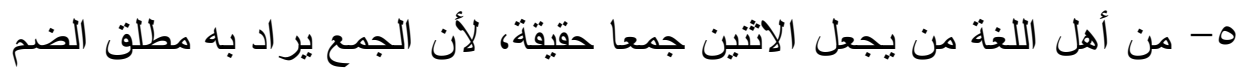

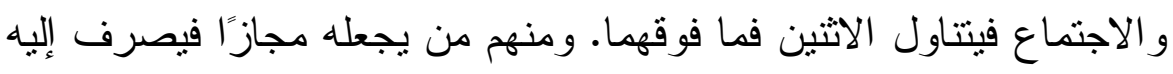

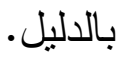

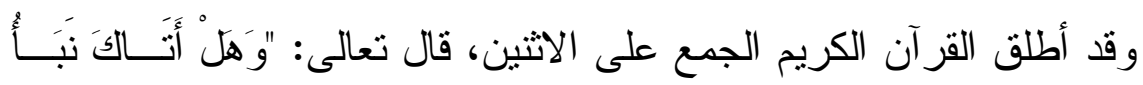

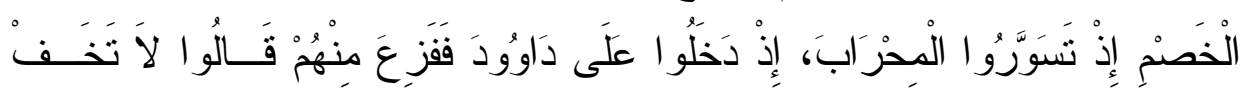

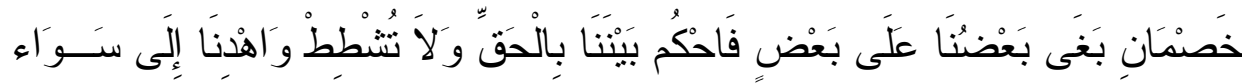

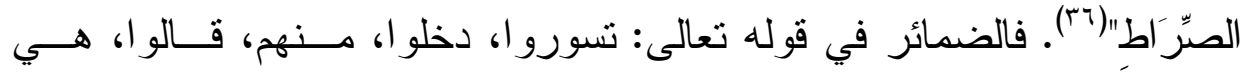

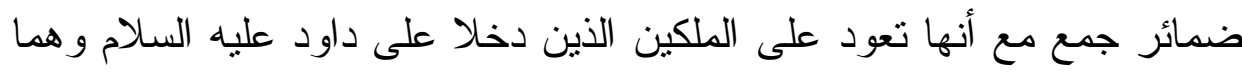

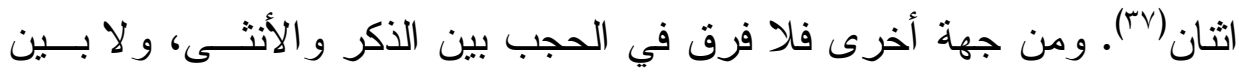

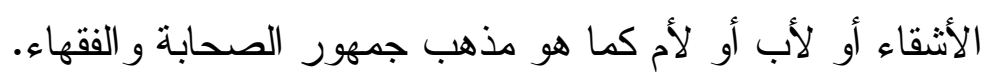

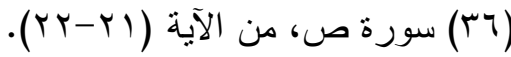

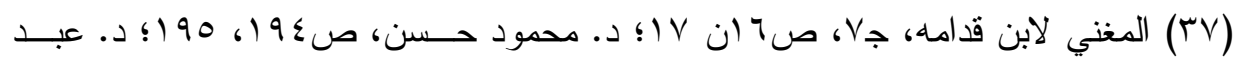

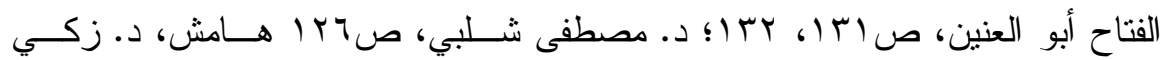

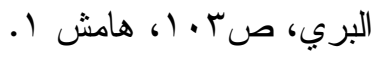

مجلت البحوث القانونيت والإقتصاديت 
ولكن معاذ بن جبل و الحسن البصري ذهبا إلى أنه لا يحجـب الأم مـن

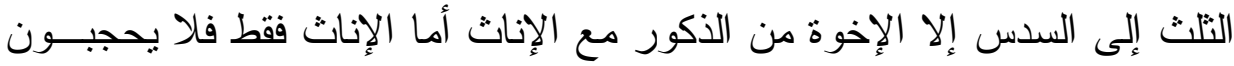

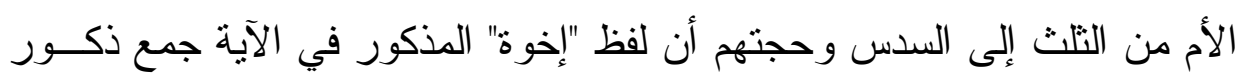

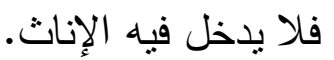

ويرد على هذا بأن لفظ إخوة "يشمل الأخوات المنفردات عــن الإخــوة الذكور على سبيل النظليب وهو جنس يشمل الإخوة الذكور و الإناث.

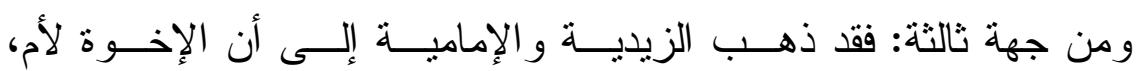

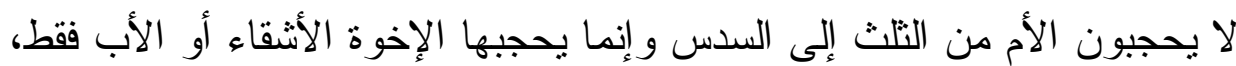

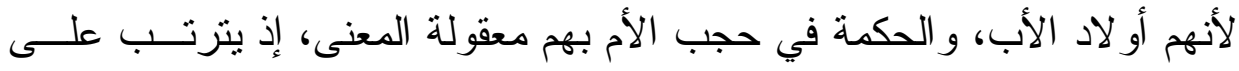

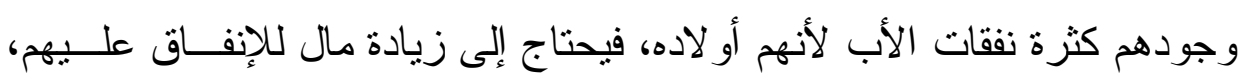

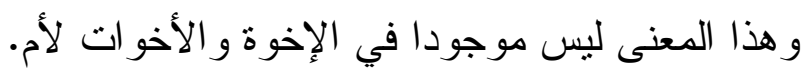

\section{و واستدلالهم هذا مردود بما يلي:}

1- لفظ "الأخوة" حقيقة في الأصناف الثلاثة "أن لفظ الأخ يُطلق على من جاور

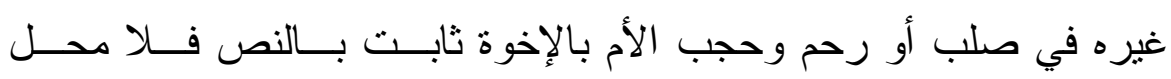
لتخصيص النص ببعض الإخوة دون بعض.

r- و أيضًا لو كان السبب في حجب الأم من التلث إلى السدس هو كثرة نفقـات

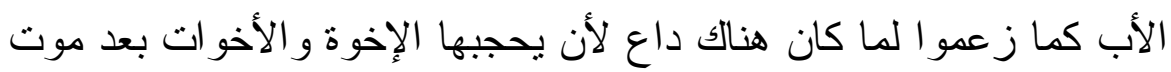
الأب، أو كانو ا كبار ا يعولون أنفسهم و لا ينفق عليهم الأب، لكن المتفق عليه 
عند الجميع أن الإخوة والأخوات يحجبون الأم ولو كانو اكبارًا، أو حتى بعد

$$
\text { موت الأب. }
$$

بقيت مسألة أخيرة، فيما يتعلق بالأخوة الذين يحجبون الأم من التلث إلى السدس وهي أن جمهور الفقهاء يرون أن السدس الذي حجبوا الأم عنــهـ يكــون للأب وروي عن ابن عباس في المشهور عنه أن الإخوة يأخذون السدس الـــي

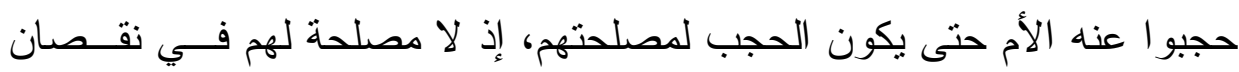

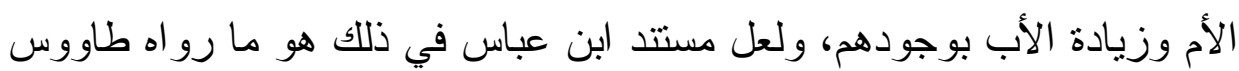

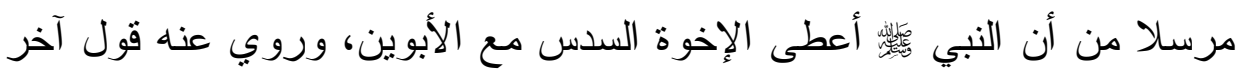

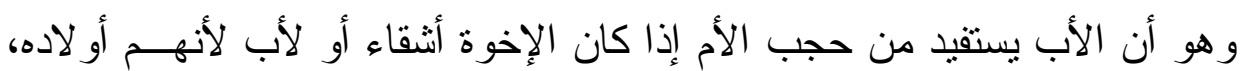

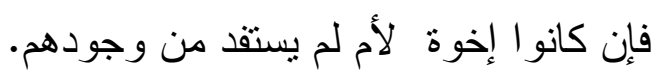

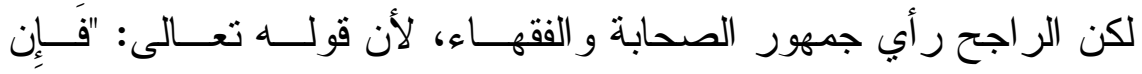

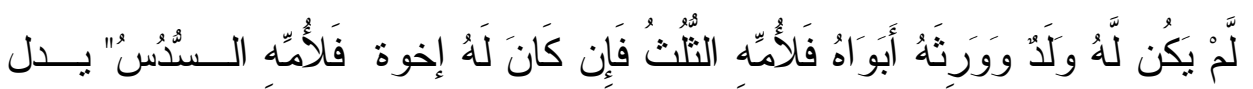

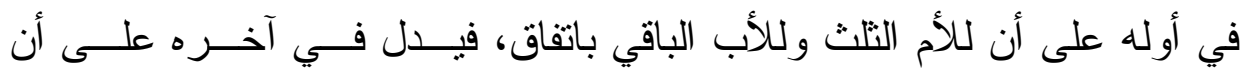

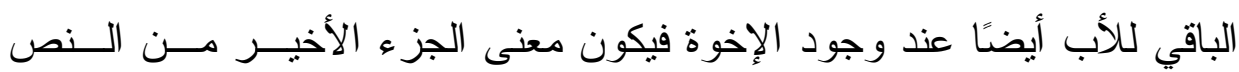

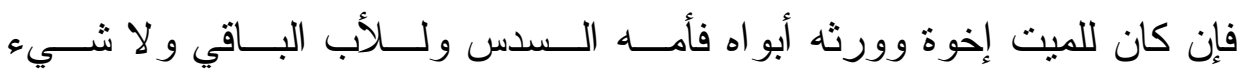
ل - ل الإخوة.

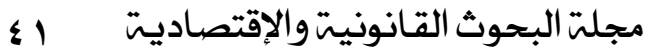


و أيضًا، فإنه لا يشترط في الحاجب أن يأخذ ما يحجبه و إنما يشترط فيــهـ

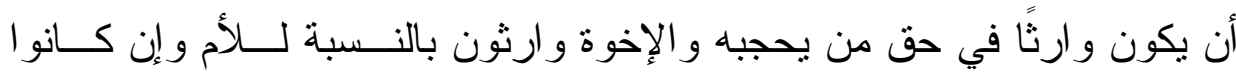

محجوبين بالنسبة للأب، أما الحديث المرسل فقد روي عن طاووس راويـهـ: أن

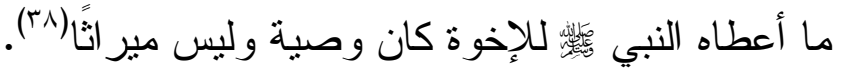

الحالة الثالثة: ترث الأم تلث الباقي من التركة بعد نصيب أحد الــزوجين فــي مسألثنين اثثتين على سبيل الحـصر ، مـشهورتين بـين الفقهـاء

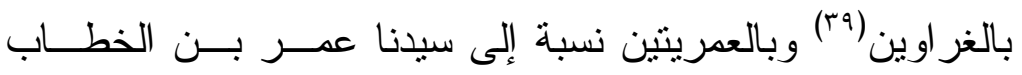
لقضائه فيهما بذلك.

المسالة الأولى: إذا توفيت امر أة وتركت زوجًا وأبا و أما فإن للـزـوج النــصف

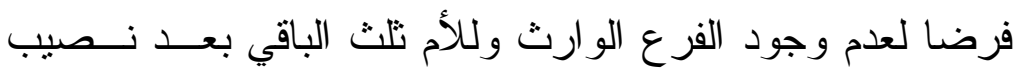

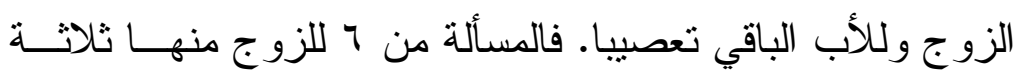

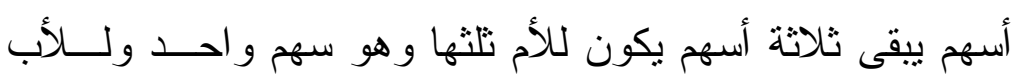
الباقي تعصييا و هو سهمان.

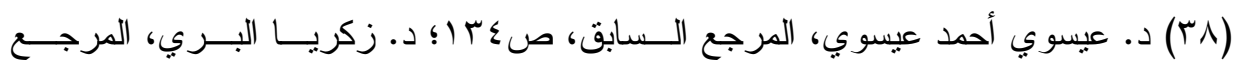

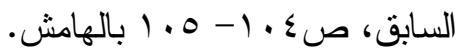

$$
\begin{aligned}
& \text { (ب9) الغراوان تثنية غراء، تثبيها للمسألثين بالكوكب الأغر لثهرتهما. } \\
& \text { مجلتً البحوث القانونيتوالإقتصاديت }
\end{aligned}
$$


المسألة الثانية: إذا توفى رجل وتزك زوجة و أبا وأما، فإن للزوجة الربع وللأم تلث الباقي بعد نصيب الزوجة وللأب الباقي تعصيبا.

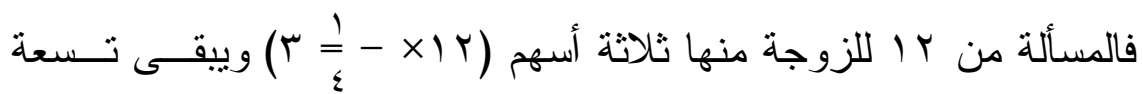
أسهم يكون للأم تلثها و هو ثلاثة أسهم وللأب الباقي وهو ستة أسهم.

هاتان هما المسألتان العمريتان أو الغراوان، وبهذا قضى فيهما عمر بـن

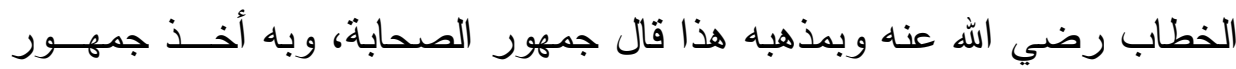
الفقهاء، وجرى عليه قانون المو اريث كما سنرى.

وخالف في ذلك ابن عباس(·) رضي الله عنه حيث يرى أن للأم تلث كل التركة في المسالتين وبقوله هذا أخذ شــريح القاضــي و ابــن ســيرين، وداود الظاهري و الثنيعة الإمامية وحجتهم في ذلك ما يلي:

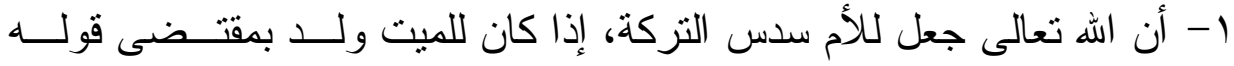

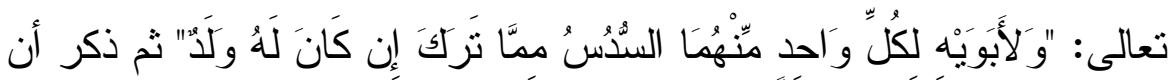

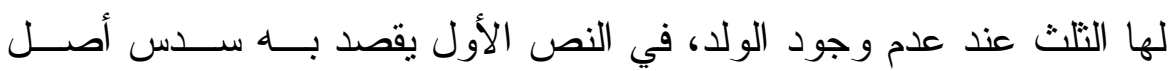

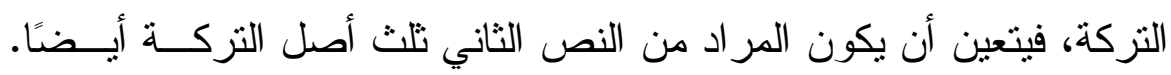

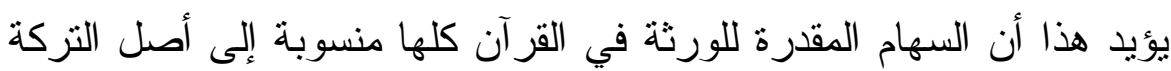


بعد الوصية و الديْن. ولذلك كان ابن عباس يقول: "لا أجد في كتاب الله تلث ما بقي).

ץ- يقول النبي

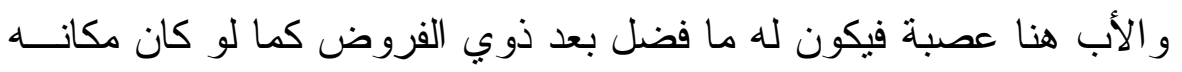

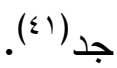

\section{أما الجمهور فيحتج لهم بما يلي:}

1- أن الأب و الأم في أصول الميت كالابن و البنت في فروعه، لأن السبب فـي

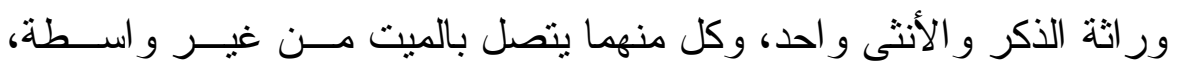
ومعلوم أن حق الابن و البنت مع أحد الزوجين هو الباقي بعد فرضه يقـسم

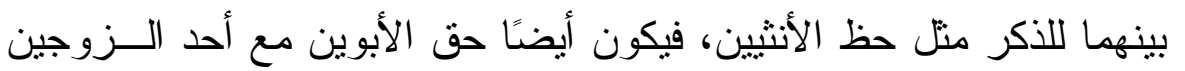
هو الباقي من التركة بعد فرضه يقسم بينهما على الوجه الذي قسم بين الابن

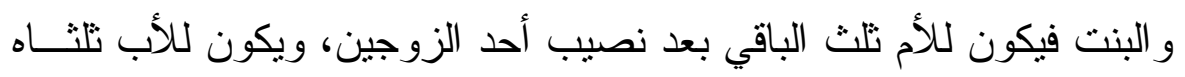
بطريق التعصيب.

r- أن الأبوين إذا انفردا بالمير اث كان نصبي الأم نصف نصيب الأب، بــص أنص

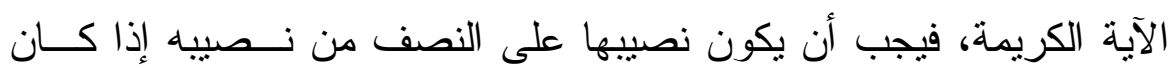
معهما أحد الزوجين. 
ب- لو أخذت الأم تلث التزكة كلها مع أحد الزووجين للــزم أن تأخــذ ضـــف نصيب الأب إذا كان معهما زوج حيث يكون نصيبها اثثين من ستة ونصيب

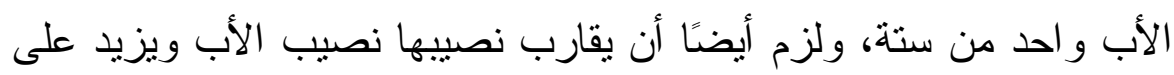
نصفه إذا كان معهما زوجة حيث يكون نصيبها أربعة أسهم من اثنى عـشر ونش

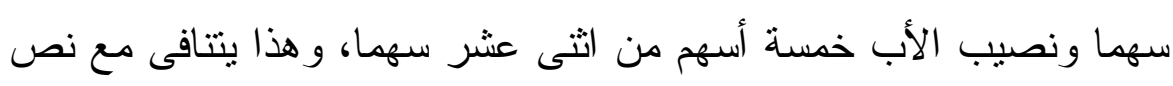

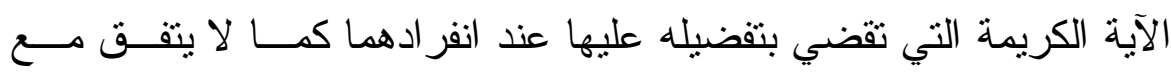

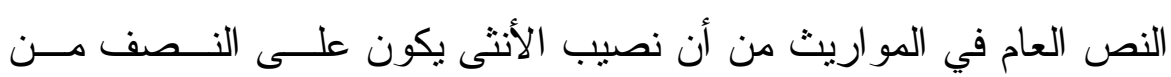

$$
\text { نصيب الذكر الذي هو في درجتها(؟؟ء). }
$$

و لا حجة لابن عباس في استدلاله بالآية الكريمة لأن المر اد مــن التلـــث

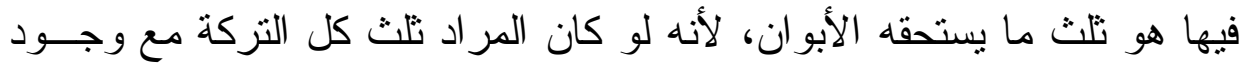

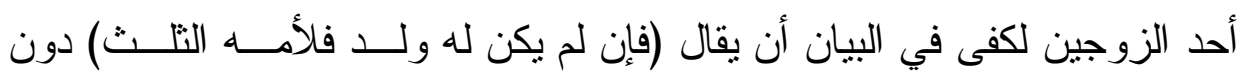
حاجة لأن يقول (وورثه أبو اه) فيلزم أن يكون قوله تعالى (وورثه أبــواه) خاليـــا

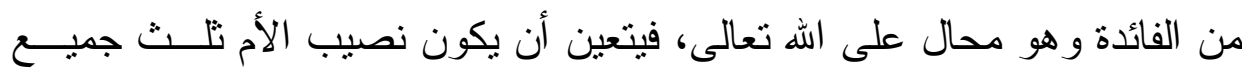
التزركة إذا انحصر الميراث في الأبوين فقط إعمالا لقوله تعالى (وورثـــهـ أبــواه)

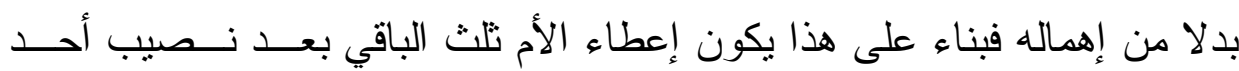
الزوجين مستفادا من الآية الكريمة.

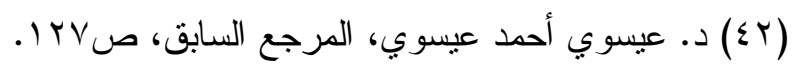

مجلة البحوث القانونيت والإقتصاديت ؛ 
ولو سلمنا أن المقصود بالتلث في الآية هو تلث كل التركة، فإن استحقاق

الأم له مشروط في الآية بشرطين: أولهما: عدم الولد أخذا من قوله تعالى: "فإن الن

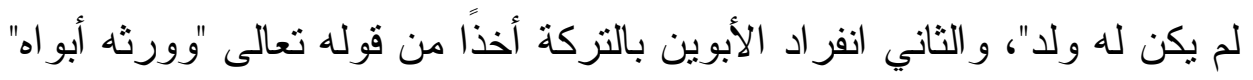

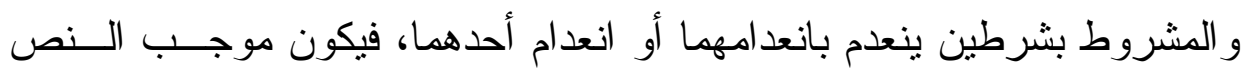

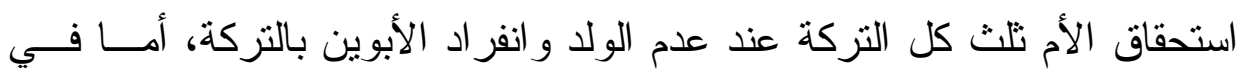

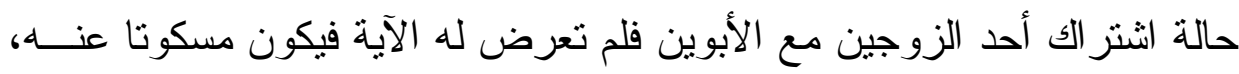
ولذلك لما سال ابن عباس زيدا: هل تجد في كتاب اله تلث ما بقـي؟ قــال: لا،

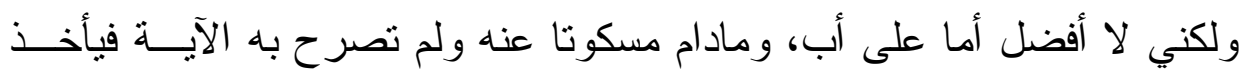

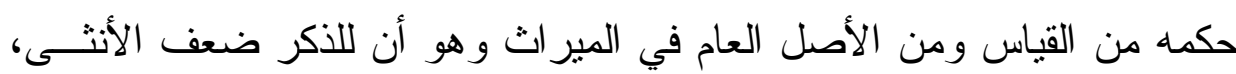

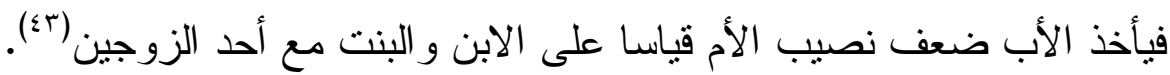
و إذا كان مع الأم جد صحيح بدل الأب أخذت الأم تلـــث جميــع المــال لا تلث الباقي بعد نصيب أحد الزوجين وهذا هــو مــذهب جمهـور الـصحابة وجمهور الفقهاء وبه أخذ القانون. وذهب أبو يوسف من الحنفية إلى أن الجد كالأب في هذه الحالة فيكـون للأم معه ثلث الباقي بعد نصيب أحد الزوجين. 
هذا وينبخي أن يلاحظ أن الأم لا ترث إلا بالفرض في جميــع أحوالهـا،

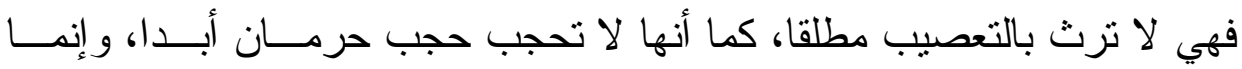
تحجب حجب نقصان من الثلث إلى السدس إذا كان معها ولد، أو كان معها عدد من الإخوة و الأخوات كما ر أينا فيما سبق.

\section{ثانيًا: ميراث الجدات الصحيحات

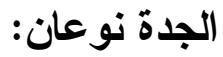

جدة صحيحة: وهي الني لم يدخل في نسبتها إلى الميت جد غير صحيح، بأن لم

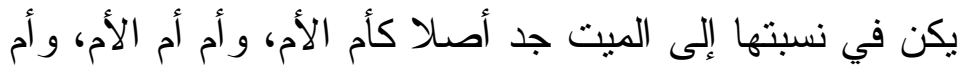

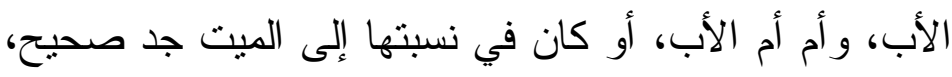
كأم أبي الأب، وأم أبي أبي الأب. أو هي التــي تتـسب إلــى الميت بصاحب فرض هو الأم، أو بعاصب هو الجد الصحيح.

جدة غير صحيحة: وهي كل جدة يدخل في نسبتها إلى الميت جد غير صــيح كأم أبي الأم، وأم أبي أم الأب، وقد وضع الفقهاء لها ضـــابطا هو : كل جدة بدخل في نسبتها إلى الميت أب بين أمين (؛ ؛). 
و إليك الرسم التوضيحي التالي حتى تتبين الجدة الصحيحة من غير الصحيحة:
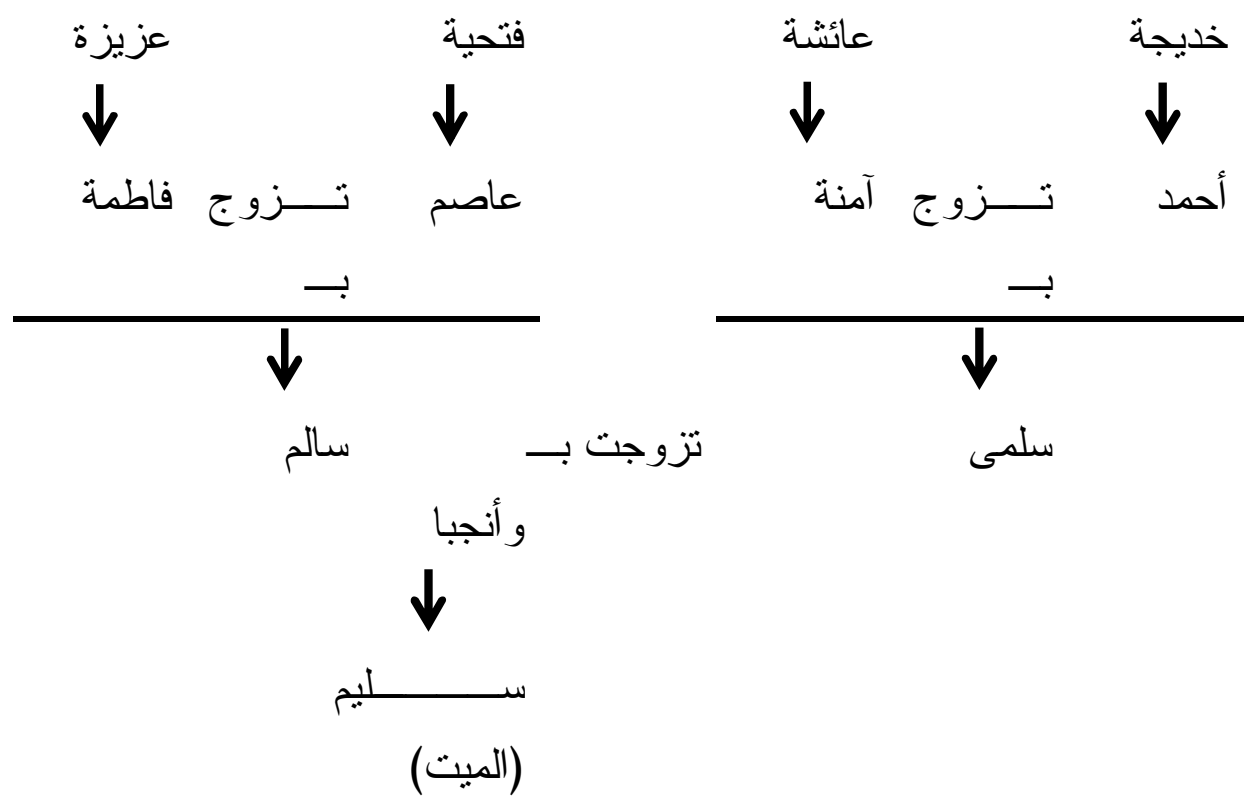

فسليم في هذا الرسم التوضيحي له ست جدات ليس فيهن سـوى جــدة واحدة غير صحيحة هي خديجة لأنها أم لأب أمه، فهي تدلي إلى سليم بجد غير صحيح هو أحمد لأنه أب أم. أما الجدات الصحيحات فهن:

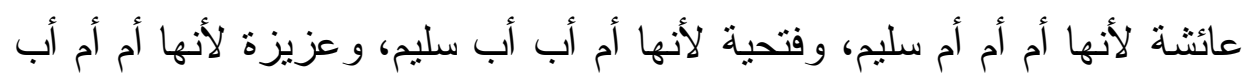
سليم، و آمنة لأنها أم أم سليم، وفاطمة لأنها أم أب سليم. 
و الجدة الصحيحة هي التي ترث بالفرض، وهي المر ادة هنا بخلاف الجدة

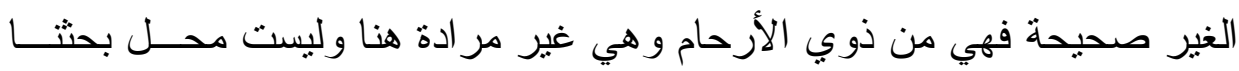
في هذا الوضع.

و الجدة الصحيحة قد تكون أمية فقط أي من جهة الأم، وقد تكـــون أبويـــة فقط أي من جهة الأب، وقد تكون أمية و أبوية كما في الجدة ذات القر ابتين.

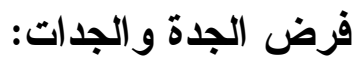

الجدة الصحيحة نرث السدس فرضا إذا لم يكن معها أم سو اء كانت هــــه

$$
\text { الجدة من جهة الأم أو من جهة الأب(ه؛). }
$$

فإذا توفيت عن زوج وجدة وعم شقيق كان للزوج النصف فرضا وللجــدة

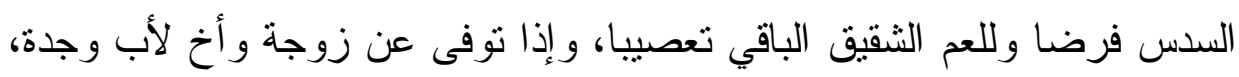
كان للزوج الربع فرضا وللجدة السدس فرضا، و الباقي للأخ لأب تعصيبًا.

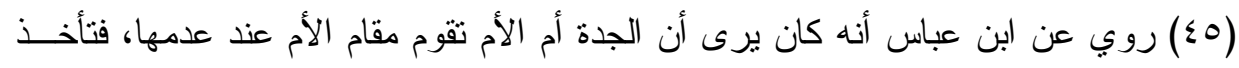

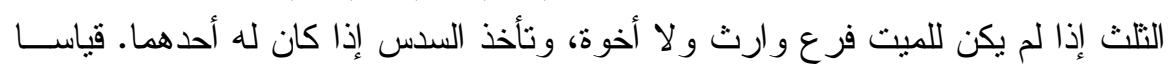

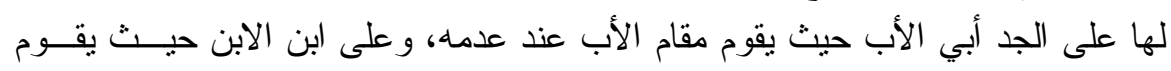

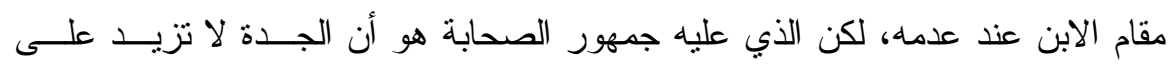

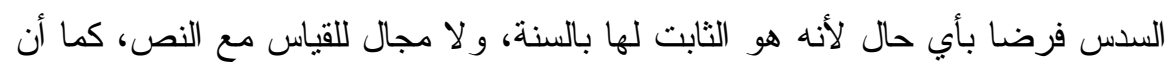

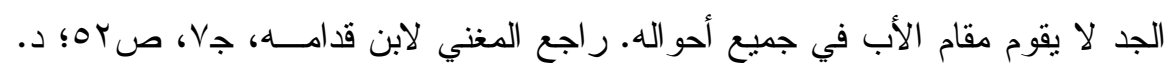

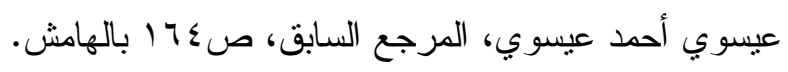


و إذا تعددت الجدات اثتتركن في السدس يقسم بيــنهن الـسوية إذا كـنـ متحاذيات "أب منساويات في الدرجة" كالجدة أم الم مع الجدة أم الأب، وكالجــــة أم أم الأم مع الجدة أم أب الأب.

فإذا مات عن زوجة وجدة هي أم أم، وجدة هي أم أب وأخ شقيق كسـان للزوجة الربع فرضا، وللجدتين السدس يقتسمنه بالسوية، و الباقي لــلأخ الــشقيق تعصيبا.

هذا والجدات الصحيحات المتحاذيات أو المنساويات في الدرجة يقتسمن السدس بالسوية لا فرق بين الجدة ذات القر ابتين وذات القر ابة الو احدة.

فإذا مات عن زوجة وجدة هي أم أم أم وهي في الوقت نفـسه أم أبــي

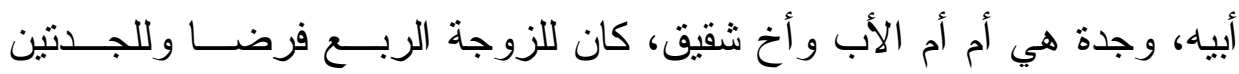
السدس فرضـا مناصفة لا فرق بين الجدة ذات القـــــنين و الجــــة ذات القر ابــــة الو احدة، و الباقي للأخ الثقيق تعصيبا، وصورة ذللك تتحقق بأن تزوج امر أة ابـن ابنها من بنت بنتها، فولد لهما ولد، فهذه المر أة جدة لهذا الولد من جهة أبيه لأنها

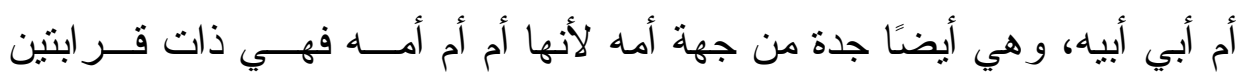

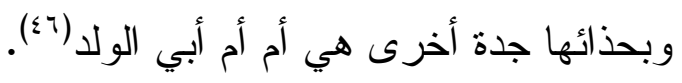


ويمكن توضيحها بالرسم البياني الثالي:
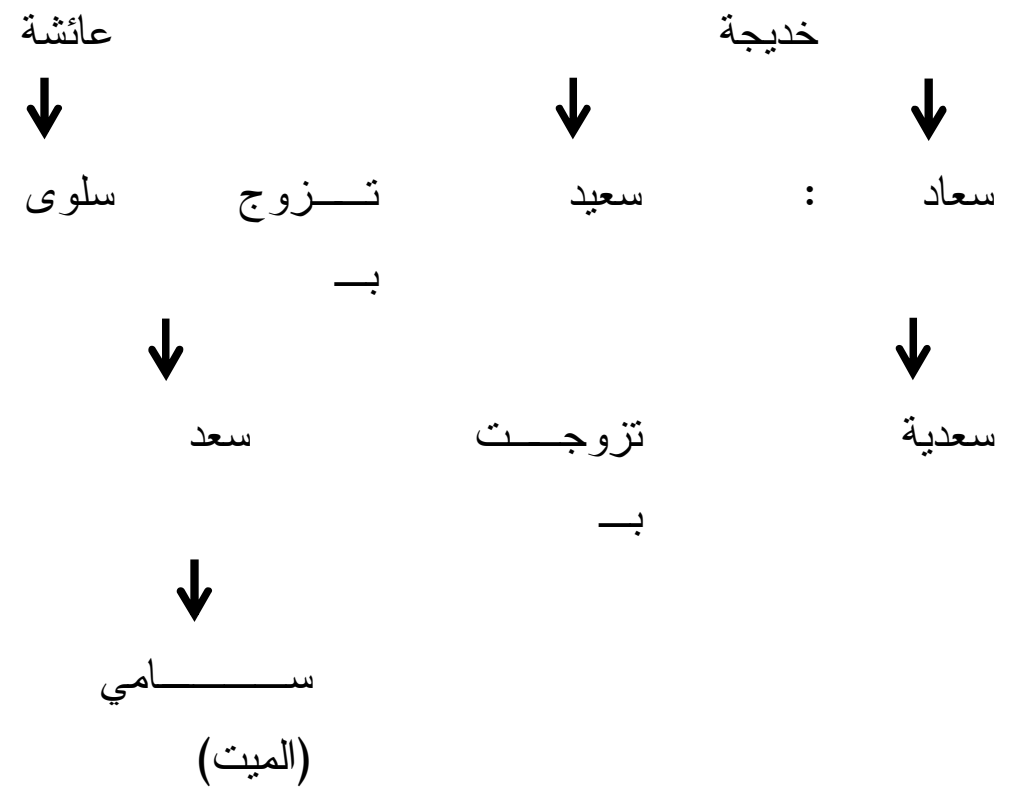

فخديجة جدة ذات قر ابتين، لأنها أم أم سامي، وفي نفس الوقت أم أبـي

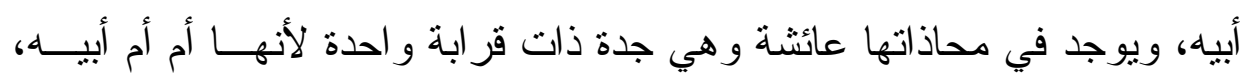
فهاتان الجدتان تقتسمان السدس مناصفة لا تفضل إحداهما الأخرى.

و هذا هو ما ذهب إليه أبو يوسف، وسفيان الثوري و الثشافع، وهو قياس

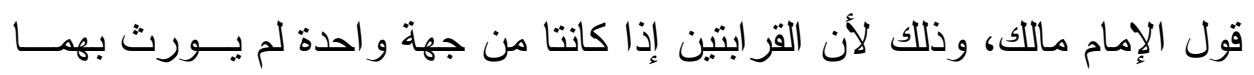

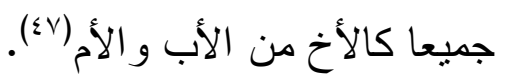

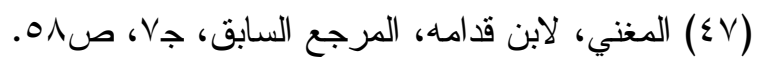

مجلت البحوث القانونيت والإقتصاديت 
وذهب محمد بن الحسن وزفر من الحنفية، وهو قياس قول أبي عبــــ الله

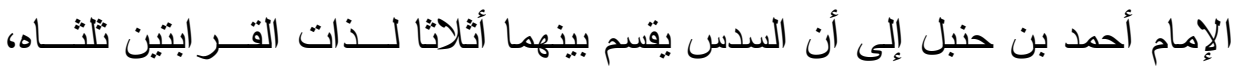

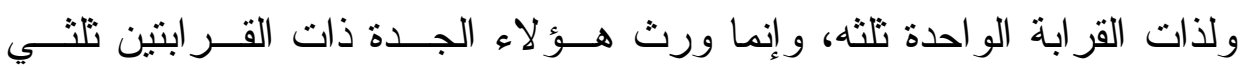
السدس لأنها لما كانت ذات قر ابتين ورثت بكل واحدة منهما كابن العم إذا كسـان زوجًا.

و الر اجح هو الرأي الأول، وذللك لن تعدد قرابة الجدة لم يترتب عليه اسم جديد لها ترث به، فهي بالقر ابتين جدة، وبالقر ابة الواحدة جدة. فكان هذا التعـد في حكم الجهة الو احدة فتشترك الجدتان في السدس مناصفة. الاليل على فرض الجدة أو الجدات:

و السدس الذي هو فرض الجدة أو الجدات إذا تعددن ثابت بالسنة المطهرة و إجماع الصحابة رضو ان الله عليهم. فقد روي أصحاب السنن عن قبيصة بن ذؤيب قال: جاءت الجدة إلى أبي بكر فسألته مير اثها فقال: ماللك في كتاب اله شيء وما علدت للك في سنة رسول الله حضرت رسول الله مسلمة الأنصاري فقال متل ما قال المغيرة بن شعبة، فأنفذه لها أبو بكر ـ قال: ثم جاءت الجدة الأخرى إلى عمر فسألته مير اثها، فقال مالك في كتاب الله شـيء، 
ولكن هو ذاك السدس، فإن اجتمعتما فهو بينكما و أبكما خلت به فهو لهـا، وروي أن التي جاءت إلى أبي بكر هي الجدة أم الأم و التي جاءت إلى عمر هي الجــدة

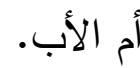

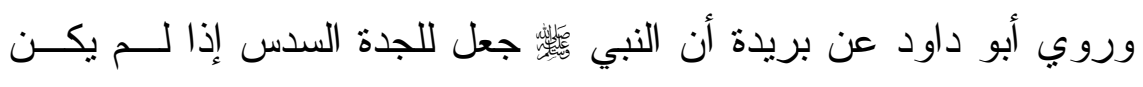

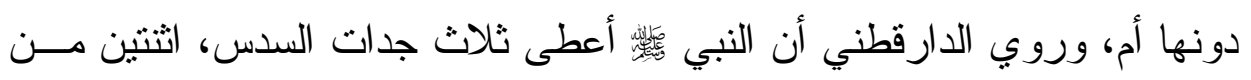
قبل الأب وو احدة من قبل الأم.

وروي الثعبي عن عمر بن الخطاب رضي الله عنه سئل عن أربع جدات

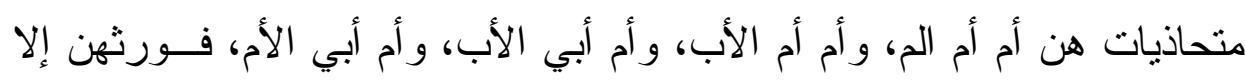
الأخيرة لأن في نسبتها إلى الميت جدا غير صحيح. فهذه الأحاديث تدل في جملتها على أن فرض الجدة الواحدة السدس وهــو أيضًا فرض الجدات إذا تعددن وكن متحاذيات أي منساويات في الدرجة.

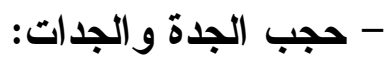
تحجب الجدة عن المير اث في الحالات الآتية:

أولاً: تحجب الجدة أو الجدات بالأم، فلا مير ات للجدة من أي جهة كانــت مــع

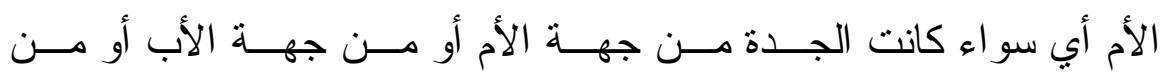
الجهتين. 
أما حجب الجدة الأمية بالأم فلأنها تدلي بها إلى الميت، و القاعدة أن مـن يدلي إلى الميت بشخص لا يرث مع وجود ذلك الثخص.

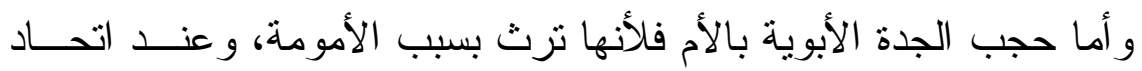

$$
\text { السبب يقدم الأقرب و لاشكك أن الأم أقرب من الجدة. }
$$

فإذا مات عن زوجة وأم و أخ شـقيق وجــدة أم أم، وجــدة أم أب، كسـان

للزوجة الربع فرضا وللأم التلث فرضا وللأخ الثقيق الباقي، و لا شيء للجـــنين لحجبهما بالأم.

ثانيًا: تحجب الجدة الأبوية أب التي من جهة الأب، بالأب، لأنها تدلي بــه إلـى

$$
\text { الميت فلا نرث معه كما أنه أقرب منها. }
$$

فإذا نوفى عن زوجة وابن و أب وجدة هي أم أب كــان للزوجــة الــثمن

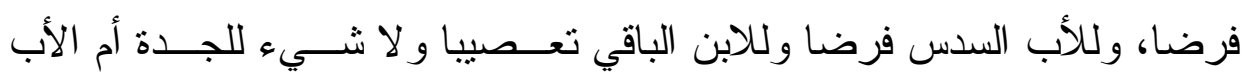
لحجبها بالأب.

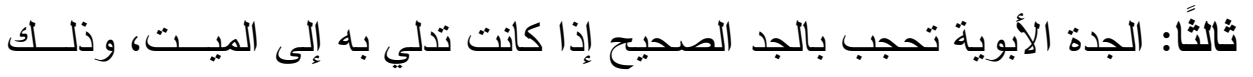

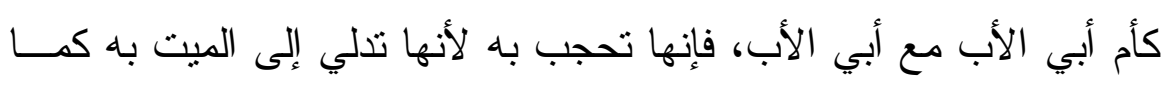
أنه أقرب منها درجة إلى الميت. 
فإذا ماتت عن زوج و ابن وجد هو أب أب، وجدة هـي أم أب أب كسـان للزوج الربع فرضا، وللجد السدس فرضا و الباقي للابن تعصيبا، و لا شيء للجدة أم أبي الأب لحجبها بالجد أبي الأب.

أما إذا كانت الجدة الأبوية لا تدلي بهذا الجد الصحيح، فإنه لا يحجبها ولا تسقط به و إنما ترث معه كأم الأب مع أبي الأب لأنها زوجته فلا تدلى به، وكأم أم الأب مع أبي الأب لأنها أم زوجته وليست قر ابتها من جهته.

ويلاحظ أن الجد الصحيح لا يحجب الجدة الأمية لأنها لا تدلى إلى الميت

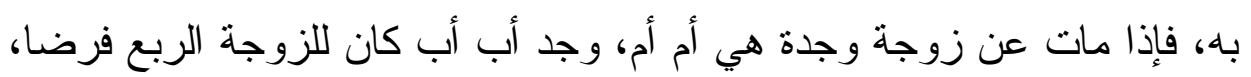

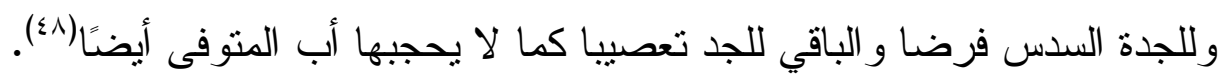

رابعًا: الجدة القربى من أي جهة كانت تحجب الجدة البعدي من أي جهة كانـــ.

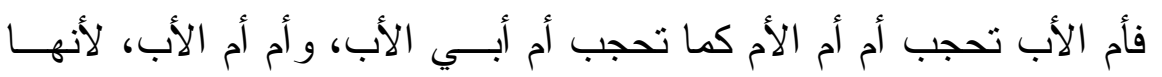

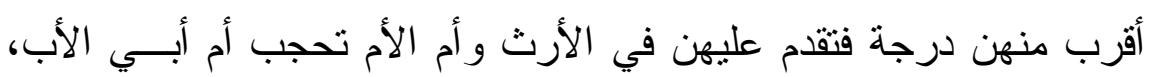

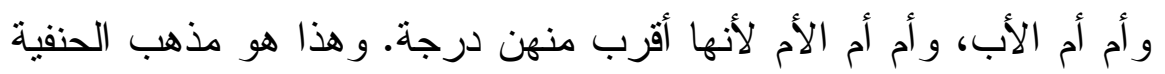

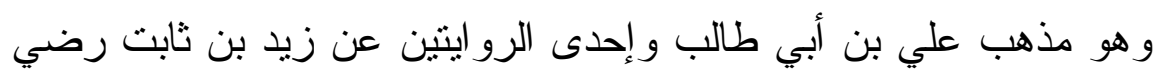
الله عنه.

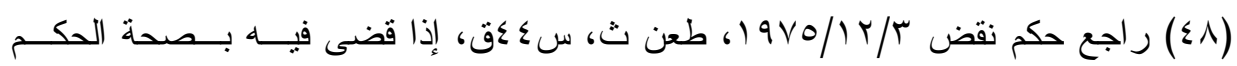
بتوريث الجدة أم الأم مع وجود الأب وكان قاه طلاع طعن في الحكم بتوريثها.

مجلتّ البحوث القانونيت والإقتصاديت هـ 
وذهب مالك وهو الصحيح عن الثافعية، وهو رو اية أخرى عن زيد بـن

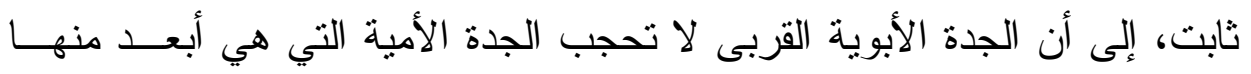

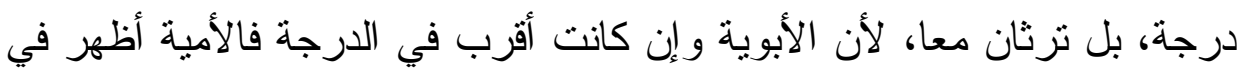

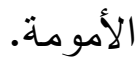

و الراجح هو ما ذهب إليه الحنفية، لأن ميراث الجدات هو بسبب الأمومة

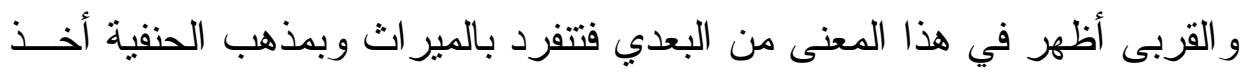

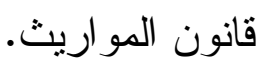

هذا و القربى من الجدات تحجب البعدى دائما، سو اء كانت القربى وارثـــة

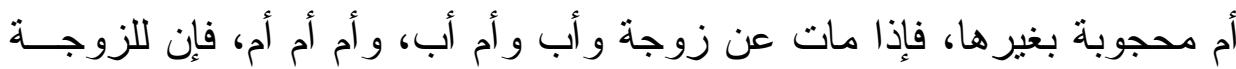

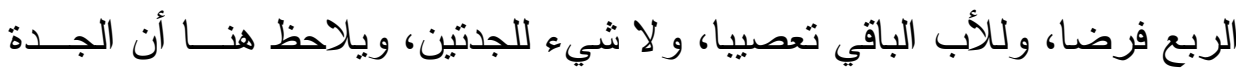

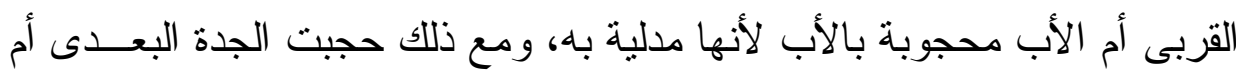

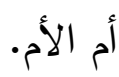

ثالثًا: أحوال البنات الصلبيات في الميراث: المر اد بالبنات الصلبيات بنات المتوفى أو المتوفاة مباشرة ودون واسـطـة وهن قد يرثن بالفرض تارة وبالتعصيب تارة أخرى، و لا يحجبن عن الميــراث بأي حال ما لم يوجد مانع من مو انع الإرثى، وقد ثبت مير اثهن بمقتضى القــر آن الكريم و السنة النبوية المطهرة.

مجلتً البحوث القانونيت والإقتصاديتة 


\section{وللبنات الصلبيات في الميراث أحوال ثلاثة:}

الحالة الأولى: الإرث بالتعصيب: ترث البنــت الـــلبية أو البنــات الـــلبيات

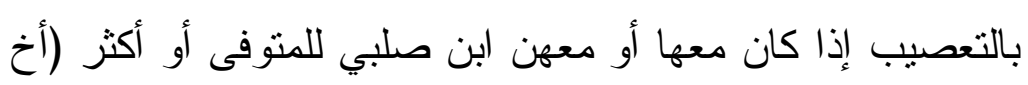

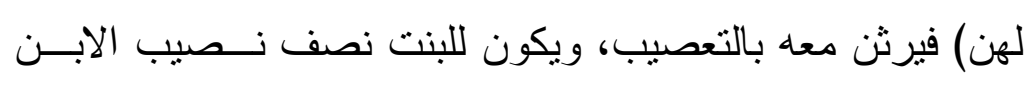
وبعبارة أخرى للاكر ضعف الأنثى، فالقاعدة أنه إذا اجتمع البنات

$$
\text { مع الأبناء كانت البنت على النصف من الابن. }
$$

فإذا توفى عن أم وبنت و ابن كان للأم سدس التركة و الباقي للبنت و الابن تعصيبًا للاكر ضعف الأنثى، وإذا توفى عن ابن وبنت كانت التزكة بينهما للبنت

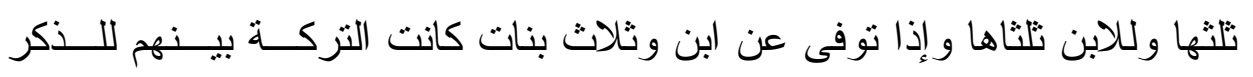

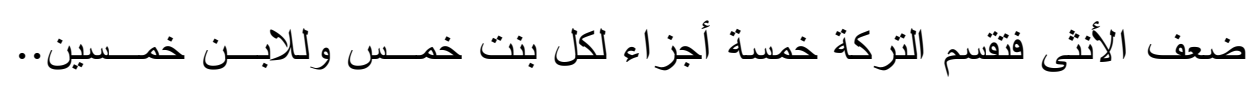
و هكذا

الحالة الثانية: الإرث بالفرض ويكــون فرضــهـا النــصف: إذا كانــت و واحـــة

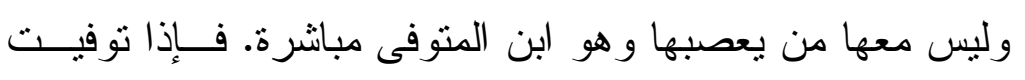

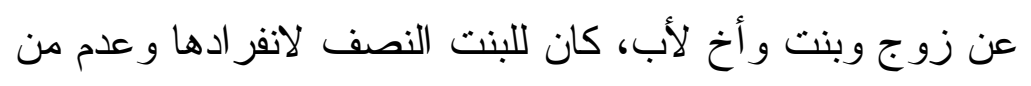
يعصبها وللزوج الربع لوجود الفرع الو ارث ولــلأخ لأب البـاقي لـاني تعصيبا. - n 
الحالة الثالثة: الإرث بالفرض ويكون فرضهن الثثثين: إذا كن اثتنين فأكثر ولم

يوجد معهن من يعصبهن كالابن. وفي هذه الحالة تشترك البنــات

في النتلثن يقتسمنه بالسوية فيما بينهن.

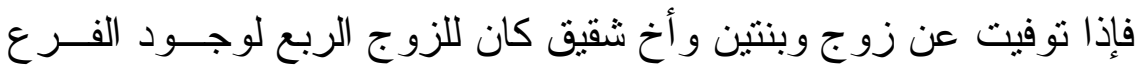

الو ارث وللبنتين التلثين لتعددهما و عدم وجود معصب لهما وللأخ الثقيق البـاقي

تعصيبا، و إذا نوفى عن زوجة وأم و آبنات و أخ شقيق، كان للزوجة الثمن فرضا

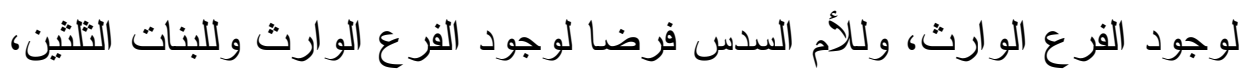

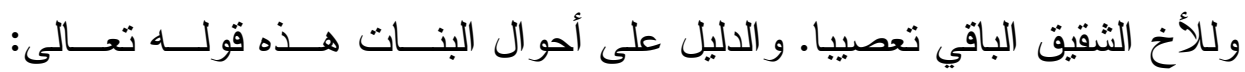

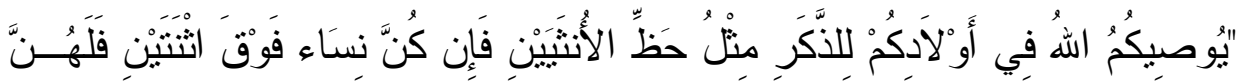

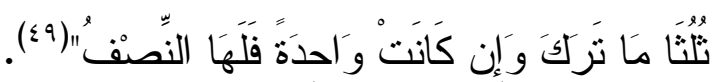

فقوله نعالى: "يوصيكم اله في أو لادكم للأكر مثل حظ الأنثين" دليل علـى الحالة الأولى، وهو يفيد أنه إذا اجتمع الأولاد من أبناء وبنات كان للأكر ضعف له الأنثىى، وقوله تعالى: "و إن كانت و احدة فلها النصف" دليل على الحالـــة الثانيــة التي تتفرد فيها البنت عمن يعصبها وتكون واحدة، وقوله تعالى: "فإن كن نـسـاء فوق اثثتين فلهن تلثنا ما ترك" دليل على الحالة الثالثة وهي ما إذا كــان البنــات

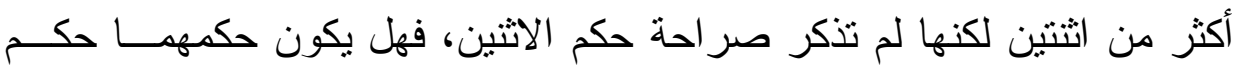




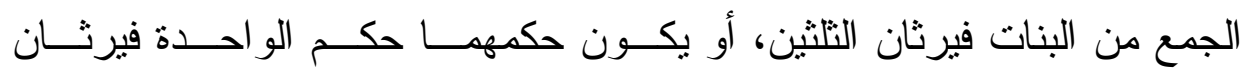
النصف.

إلى الأول ذهب جمهور الصحابة و الفقهاء، حيث يرون أن حكـــ البنتـين و الثنلاث فصاعدا فيرثان التلثين. و استدلو ا على ذلك بما يلي:

أولاً: بما روي عن جابر بن عبد الهُ قال: جاءت امر أة سعد بن الربع إلى النبـي صلى الله عليه وسلم فقالت. يا رسول اله، هاتان ابنتا سعد بن الربيع قتــل

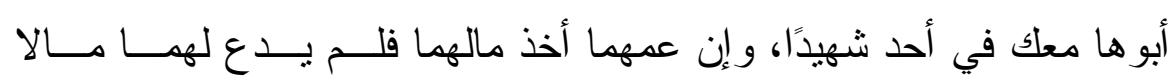

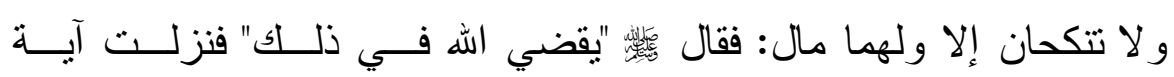

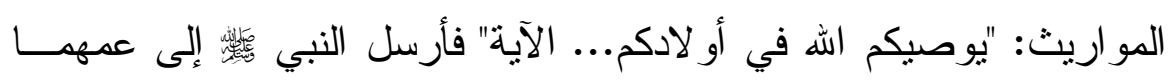

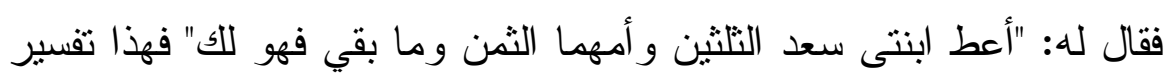
من الرسول كئس للآية التي نزلت بيانا لحكم هذه الو اقعة، يدل على أن البنتين كالبنات لهما الثلثان.

ثانيًا: قوله تعالى: "فإن كن نساء فوق اثثتين فلهن ثلثا ما تــرك" يــدل عالــى أن

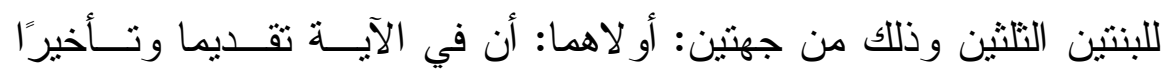

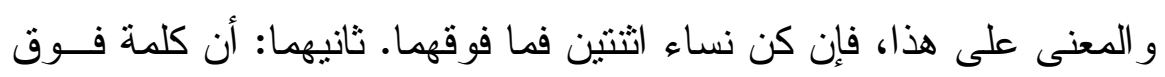

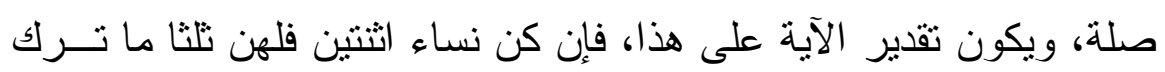

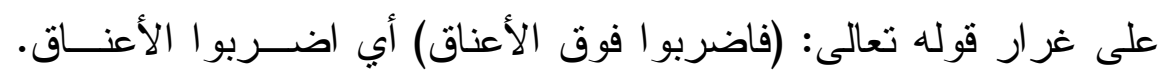
يؤكد هذا تفسير الرسول عَّل للآية في و اقعة ابنتي سعد بن الربيع. 
ثالثًا: قد بين الله تعالى في آية الكلالة نصيب الأخت الو احدة و الأختين و الإخــوة و الأخوات إذا كانو ا مختلطين فبين أن نصيب الأخت الواحدة النصف، وأن نصيب الأختين التلثين، و أنهم إذا كانو أخوة رجالاً ونساء فللذكر مثل حـــ

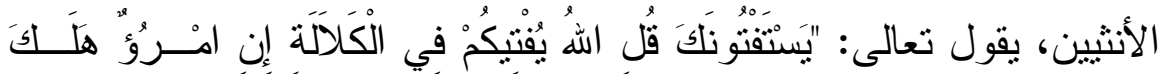

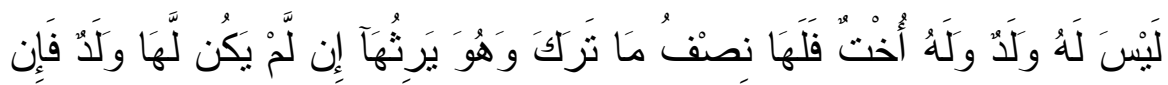

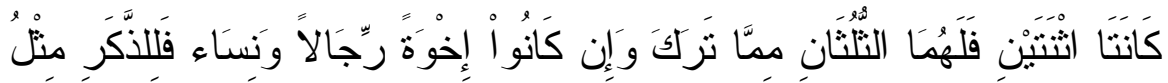

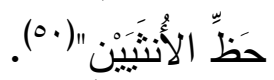

وفي آية الأولاد، قد جعل الله للبنت الو احدة النصف كمـــا جعـل الأبنـــاء يعصبن البنات، للذكر مثل حظ الأنثيين، فإذا كان الله قد أعطى للأختين الثلتهـين وهما أبعد قر ابة من البنتين، فإن البنتين تكونان أولى باستحقاق الثلثين(10).

رابعًا: قد بين الله تعالى نصيب البنت الو احدة كما بين نصيب الثلاثة فما فوق، ولم يبين نصيب البنتين، فدار الأمر بين إلحاقهما بالو احدة، و إلحاقهما بالجمع فكان

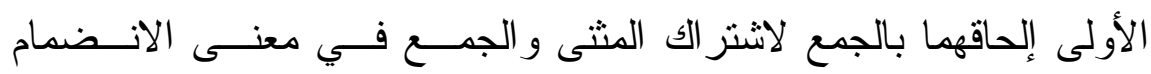

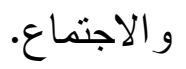

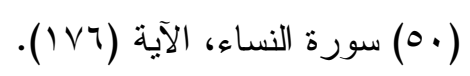

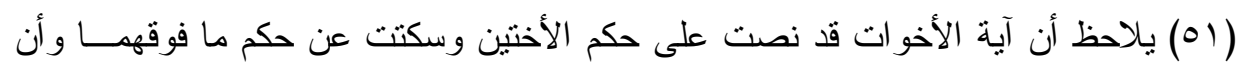

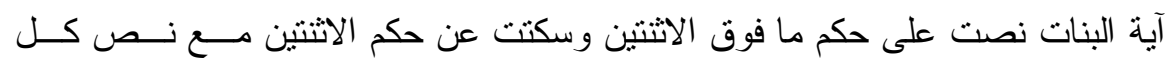

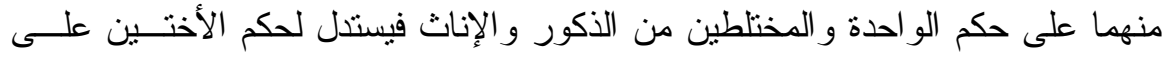

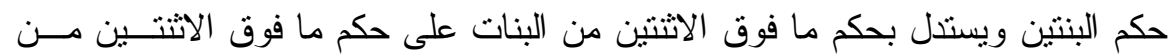
الأخوات بطريق الدالالة. 


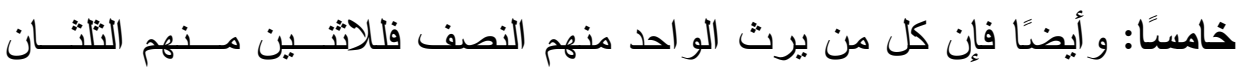

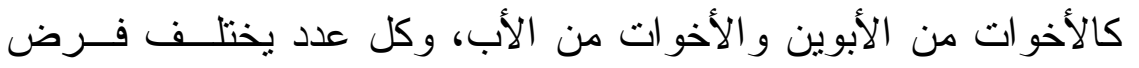
و احدهم وجماعتهم فلالثنين منهم منل فرض الجماعة كولد الأم- الأخوة

$$
\text { لأم - و الأخوات من الأبوين أو من الأب(ro). }
$$

سـادسَــا: قد ذكر بعض العلماء أنه قد انعقد الإجماع على أن للبنتين الثلثين مــن بعد عصر الصحابة فلا مجال للمخالفة(ro).

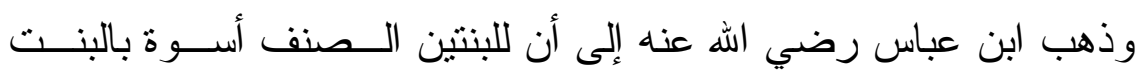
الو احدة استدلالا بظاهر الآية، فقد جعلت استحقاق التلثين الجمع من النساء وهــــ الثلاثة فصاعدا الأقل من ذلك فلفظ نساء جمع مؤكد بقوله تعالى: (فوق اثثتـين). وبقوله: "فلهن ثلثنا ما ترك"، هن، ضمير جمع. وما ذكره ابن عباس لا ينافي استحقاق البنتـين للتلتهـين لأن تخـصيص

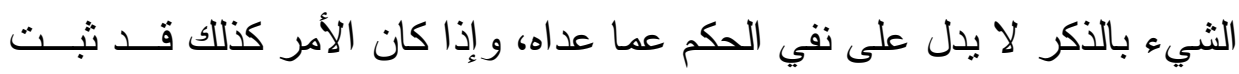
إلحاق البنتين بما ذكره جمهور الفقهاء من أدلة(ء).

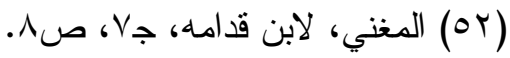

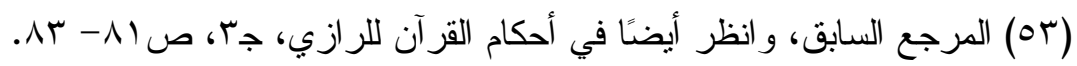

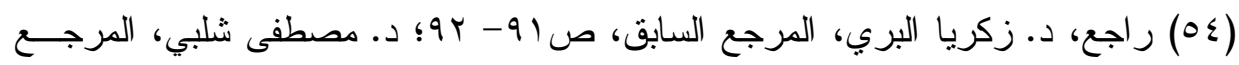

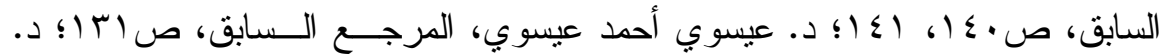

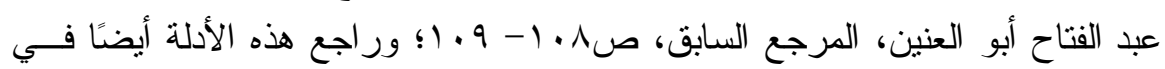

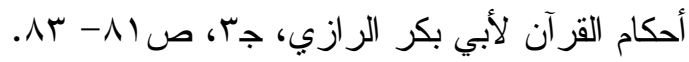


"المر اد ببنت الابن كل بنت تتنسب إلى الميت بواسطة الابن مهما نزلــــ درجة أبيها فتصدق على بنت الابن. وبنت ابن الابن، وبنت ابــن ابــن الابــن و وكذا،

وبنت الابن ترث إذا لم يكن للميت فرع و ارث أعلى درجة و أقرب درجــة

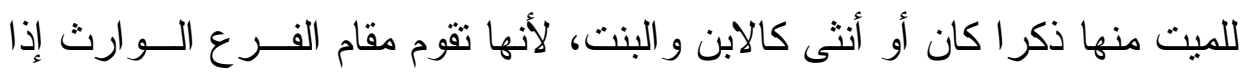

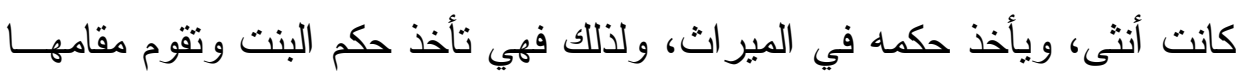

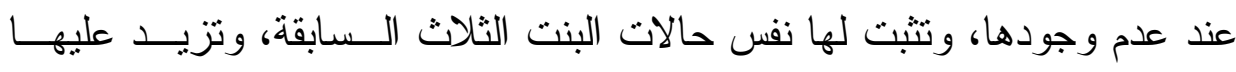
بثلاث حالات أخرى فجملة أحو ال بنت الابن في المير اث نبينها فيما يلي:

الحالة الأولى: ترث الو احدة من بنات الابن النصف إذا انفردت ولم يوجد معهـــا

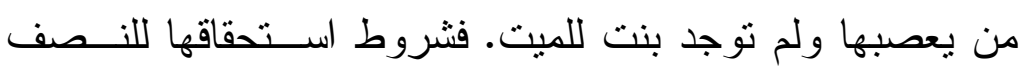
ثلاثة: - n

$$
\text { 1- انفر ادها بحيث تكون واحدة لا أخت لها. }
$$

r- عدم وجود من يعصبها، كابن ابن هو في درجتها كأخيها أو ابن عمها. r- عدم وجود أي من أو لاد الصلب، ابن أو بنت. 
فإذا نوفى عن أم وأب وبنت ابن كان للأم السدس لوجود الفرع الــوارث ولبنت الابن النصف لانفر ادها وعدم من يعصبها وعدم وجود البنــت الـصلبية وللأب السدس فرضا و الباقي تعصيبا.

و إذا نوفى عن زوجة ونبت ابن وابن ابن هو أخوها أو ابن عهها. كسان للزوجة الثن، أما بنت الابن فلا نستحق النصف هنا، لأنها صارت عصبة عصبة بابن الابن فتأخذ معه الباقي يقسم بينهما للأكر ضعف الأنثى.

و إذا توفى عن زوجة وبنت وبنت ابن وأب. فللزوجــة الــثن وللبنــت

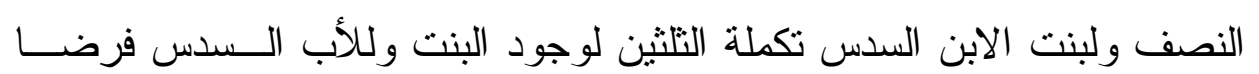
و الباقي تعصيبا.

الحالة الثانية: نرث الاثتان فأكثر من بنات الابن التلثين إذا لم يكن هناك أحــ

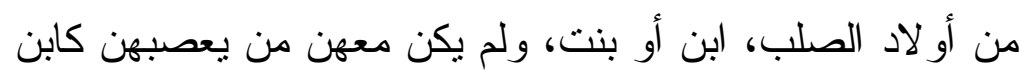

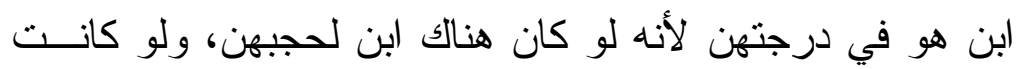

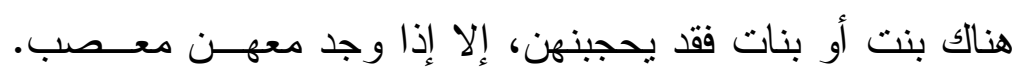
فيرثن بالتعصيب و إذا كان معهن معصب انتقلن من الاســتحقاق

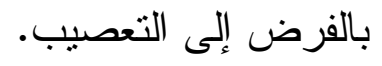

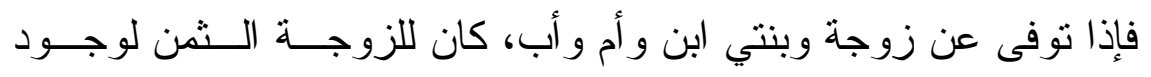

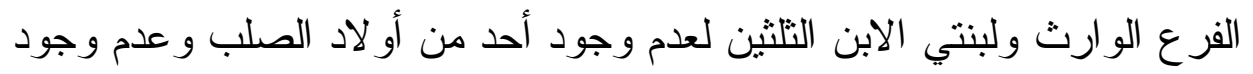




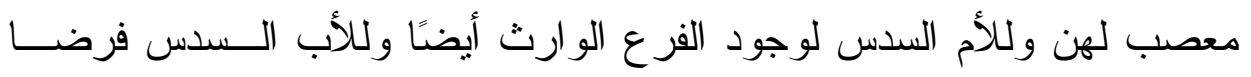
و الباقي تعصيبا. ولكن هنا لم ييق له شيء يرثه بالتعصيب لاستغراق الفــروض

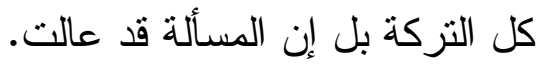

الحالة الثالثة: ترث بنت الابن أو بنات الابن بالتعصيب إذا وجد معها أو معهن ابن ابن هو في درجتها أو درجتهن كأخيها أو ابن عمها، ولم يكن

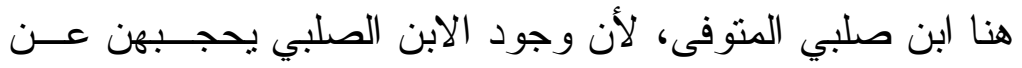
المير اث.

فإذا مات وترك ابن ابن، وبنت ابن كانت التركة بينهما تعصيبا للذكر منل حظ الأنثين فيقتسمانها لبنت الابن التلث و لابن الابن الثلثين.

و إذا مات وترك أما وزوجة وبنت ابن و ابن ابن كان للأم السدس فرضـــا لوجود الفرع الوارث وللزوجة الثن فرضا لنفس السبب ولبنت الابن وابن الابن الباقي تعصيبا للاكر ضعف الأنثى. الحالة الرابعة: ترث بنت الابن أو بنات الابن السدس تكملة التثلثن إذا كان معها

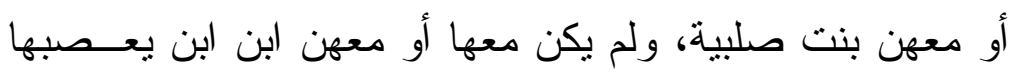
أو يعصبهن. لأنه إذا وجد مع بنت الابن أو بنات الابن معسب لصب انتقلن من الاستحقاق بالفرض إلى التعصيب كمــــــــق القـــول و الحكمة في استحقاق بنات الابن السدس هنا هو أن حق البنـات 
هو التنثين. وقد أخذت البنت الصلبية النصف، بقي السدس فتأخذه

بنت الابن أو بنات الابن إذا تعددن ولذلك يعبر عنه دائمسا بأنـــه السدس تكملة النتلثن.

فإذا توفى وترك أما و أبا وبنتا، وبنتي ابن. كان لــلأم الــسدس فرضـــا، وللأب السدس فرضا وللبنت النصف فرضا ولبنتي الابن السدس تكملة التلنهين يقسم بينهما بالتسوية.

و إذا توفى عن أم و أب وبنت ابن وثلاث بنات ابن ابن. كان للأم الــسدس

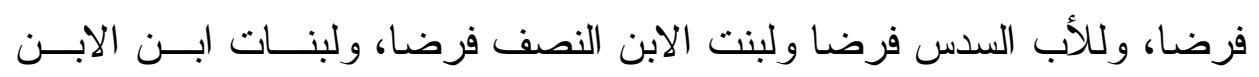
الثلاث السدس تكملة التلثين يقسم بينهن بالسوية.

فبنات الابن يرثن بالفرض مع الو احدة من بنــات الـــلب، إلا إذا كــان معهن معصب لهن في درجتهن كأخيها أو ابن عمها.

فإذا نوفى عن بنت صلبية، وابن ابن، وبنت ابن، فإن للبنت هنا النـــف

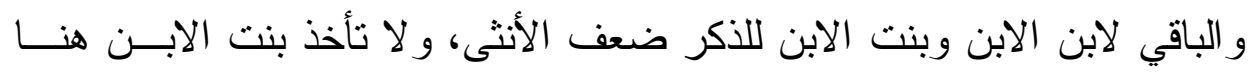
السدس فرضا لوجود معصب لها.

فإذا نوفيت وتركت زوجا و أبا وأما وبنتا و ابن ابن وبنت ابن كان للــزوج

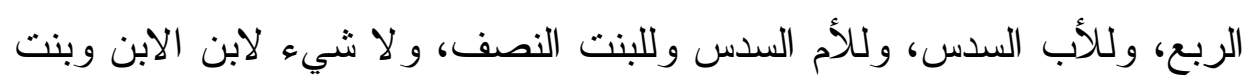


الابن لأن الفروض قد استغرقت التزكة، فلا يستحق ابن الابن وبنت الابن شــئًا لأنهم عصبة لم يبق لهم شيء.

ويُطلق على منل هذا القريب- ابن الابــن - الأخ المــشئوم أو القريــبـ المشئوم إذ لو لاه لورثت بنت الابن وكانت صـاحبة فرض و أخذت السدس ولكــن وجوده معها جعلها من العصبات.

فقي المثال السابق إذا كان الورثنة زوجا وأما وابنا وبنتا وبنت ابن أخـذت بنت الابن السدس تكملة الثلثين و عالت المسألة.

الحالة الخامسة: لا تزث بنت الابن أو بنات الابن شيئًا مع وجود بنتين صلبيتين أو أكثز إلا إذا كان معهن من يعصبهن سواء كان في درجتهن كأخيهن أو ابن عمهن أو أنزل منهن درجة. كابن ابن ابن هـــ

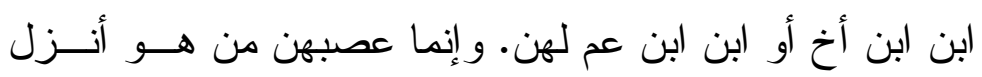
منهن درجة لاحتياجهن إليه. و السبب في عدم استحقاق بنات الابن شيئًا في هذه الحالة هو أن البنــات الصلبيات قد استوفت التثلثن وهو نصيب البنات عموما كما علمت.

أما إذا كان مع بنات الابن معصب من درجتهن أو أنزل مــنهن فـإنهن يعصبن معه ويرثن معه الباقي من التركة بعد أصحاب الفروض. 
فإذا توفى عن أم و أب وبنتين وبنت ابن أو بنات ابن. كان لــلأم الــسدس

فرضا وللأب السدس فرضا وللبنتين التلثين فرضا و لا شيء لبنت الابن أو بنات الابن لأن البنات الصلبيات قد استوفين نصيب البنات وهو التلثين.

أما إذا توفى عن بنتين، وبنت ابن و ابن ابن كان للبنتين التنتــين ولبنــت الابن و لابن الابن الباقي تعصيبا للذكر ضعف الأنثى، ويُطلق على ابن الابن هنا الأخ المبارك أو القريب المبارك إذ لو لاه لما ورثت بنت الابن.

ونفس الأمر إذا كان مع بنت الابن في مثل هذه الحالة معصب لهــا هــو

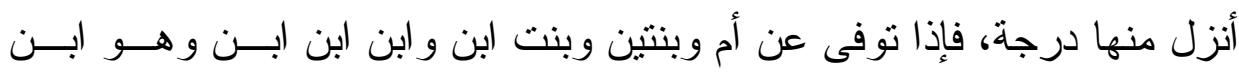

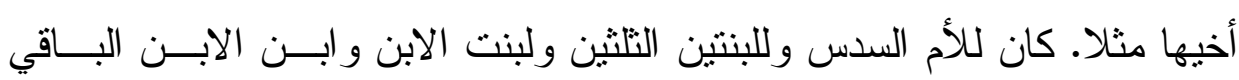
تعصيبا للذكر ضعف الأنثى.

هذا وتعصيب الذكر من أو لاد الابن، كابن الابن لبنت الابــن فــي حالـــة وجود البنتين فأكثر هو ما ذهب إليه عامة الصحابة وجمهور الفقهاء.

وذهب عبد الله بن مسعود رضي الله عنه إلى أنه لا يعـصبهن ويكـون

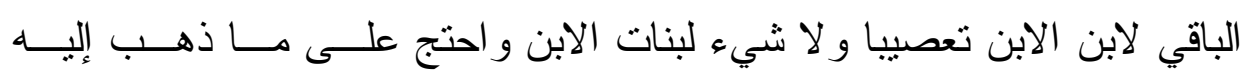
بما يلي: 
أولاً: أنه لو جعل الباقي بين ابن الابن وبنت الابن في هذه الحالة للذكر ضــعف

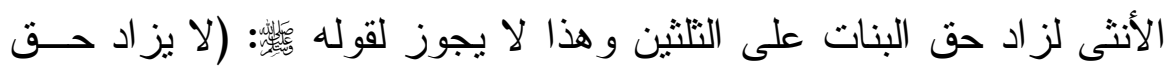

$$
\text { البنات على التلثين). }
$$

ثانيًا: أن الأنثى إنما تصبر عصبة بالذكر إذا كانت صـاحبة فرض عند انفر ادهـــا عنه كالبنات و الأخوات، أما إذا لم تكن كذللك فلا تــصبر عـصبة كبنــات الأخوة و الأعمام مع بينهم، وبنت الابن هنا ليست صـاحبة فـرض لوجــود الصلبيتين فلا تصبر عصبة بابن الابن.

$$
\text { ويُجاب عن ذلك بما يلي: }
$$

أولاً: أن استحقاق بنت الابن في هذه الحالة يختلف عــن اسـتـحقاق الــصلبتين لأن بنت الابن تستحق الميراث في هذه الحالــة بالتعــصبب و الـــلبيتان

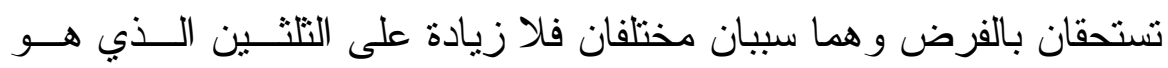
نصيب البنات لأن الممنوع هو الزيادة على التلثين بالفرضية، وهــذا لــيس موجودا. ثانيًا: أن بنت الابن صاحبة فرض عند انفر ادها عن ابن الابن ولكنهـــا حجبــــ بالصلبيتين، بدليل أنها تأخذ النصف فرضا عند عدم الصلبيات. 
و هذا بخلاف بنات الأخ وبنات العم لأنه لا فرض لهن عند الانفر اد عـن

$$
\text { ابن الأخ أو ابن العم فلا يصرن عصبة به(00). }
$$

هذا، إذا كان من يعصب بنت الابن من هو في درجتها أما إذا كان أنـزل

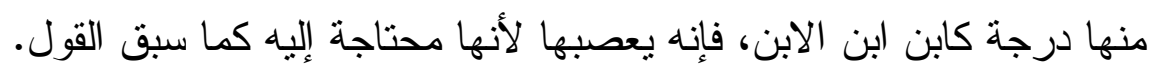

الحالة السادة: أنها تحجب بالابن الصلبي، وبابن الابن الذي هو أعلــى منهــا درجة، فبنت الابن تحجب بالابن وبنت ابن الابن تحجب بـابن

$$
\text { الابن....و هكذا. }
$$

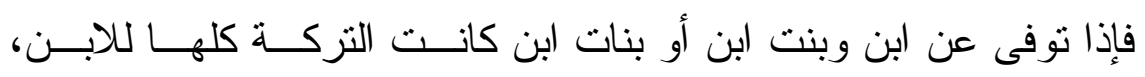

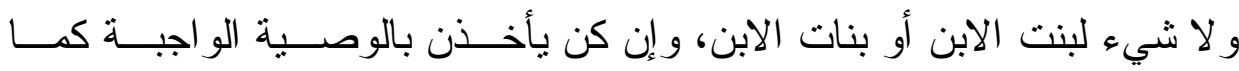

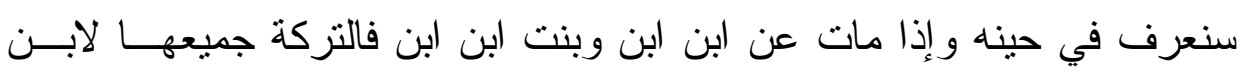
الابن تعصيبا و لا شيء لبنت ابن الابن لحجبها بابن الابن، و إن كانــت تـستحق

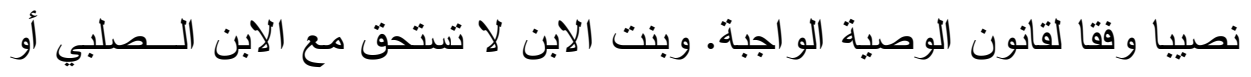

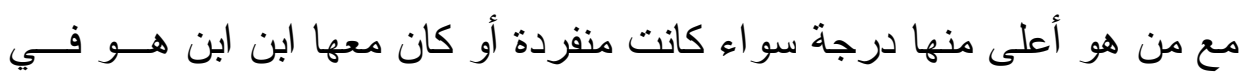
درجتها، فإذا توفى عن ابن وبنت ابن و ابن ابن، كانت التركة كلهــا للابــن و لا

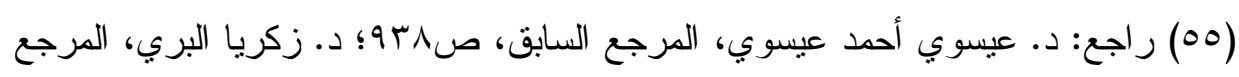
السابق، ص90 د90-97 بالهامش.

مجلت البحوث القانونيتو والإقتصاديتة 99 


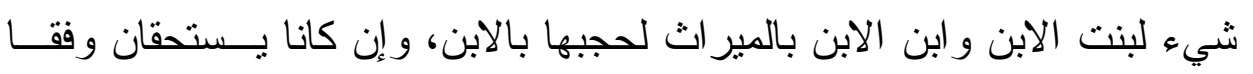
لقانون الوصية الو اجبة أيضًا.

و الدليل على مير اث بنات الابن في الحالات الثثلاث الأولى هو نفس دليــلـ توريث البنات وهو قوله تعالى: "ويوصيكم اله في أو لادكم للـــكر مثــل حـــ الأنثيين..." لأن لفظ الأو لاد كما ســـق القـول بــر اد بـــهـ الأو لاد المباثــرين أو بو اسطة الأو لاد، فكان شاملا لأبناء المنوفى وبناته و أبناء أبنائه وبنات أبنائه.

أما استحقاقها السدس المكل للتلثين فلما روي من أنه: سئل أبو موسـى

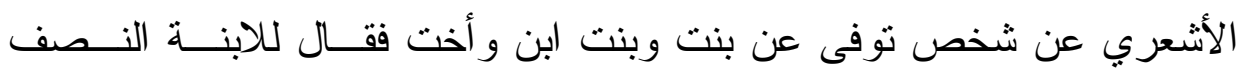
وللأخت النصف، ثم قال للسائل أنت ابن مسعود فستبايعني فسئل ابن مسعود بعد

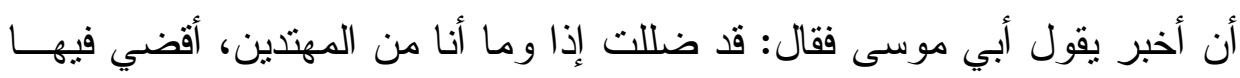
بما قضى رسول الله عاد السائل إلى أبي موسى فأخبره بقول ابن مسعود فقال: "لا تسألوني مادام هذا

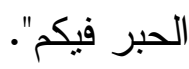

و أما عدم استحقاق بنات الابن شيئًا مع البنتين فأكثر فلأن الله تعالى جعل فرض البنات التلثين، فإذا أخذه البنات لم ييق لبنات الابن شيء فإذا كان معهـن

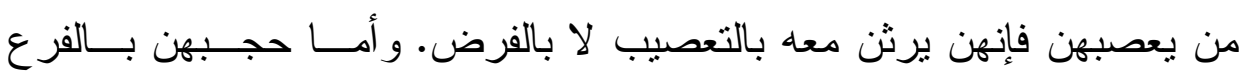

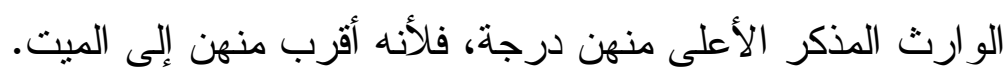




\section{خامسًا: أحوال ميراث الأخو ات الثقيقات(ه):}

الأخت الثقيقة هي أخت الميت لأبيـــه و أمـــه معــا، و الأخــت الـششقيقة أو الأخو ات الثنقيقات قد يرثن بالفرض وقد يرثن بالتعصيب، وهذا التعصيب قد يكون تعصيبًا بالغير وقد يكون تعصيبًا مع الغير، كما أنهـــا قــد تحجــب مــن المير اث في بعض الأحو ال.

\section{وللأخت الثقيقة أو الأخوات في الميراث خمس حالات هي:}

الحالة الأولى: ثرث الو احدة منهن النصف إذا لم يكن لها أخ شقيق يعـصبها ولا بنت أو بنت ابن تصبر معها عصبة ولم يوجد من يحجبها، كالابن أو ابن الابن أو الأب أو الجد عند بعض الفقهــاء كمـــاســنــى فالو احدة من الأخوات الثقيقات ثرث النصف بــشروط أربعــة: الأول: انفر ادها، و الثاني: عدم وجود أخ شقيق، و الثالـــث: عــدم وجود فرع وارث، ابن أو ابن ابن أو بنت أو بنت ابن. و الر ابــع:

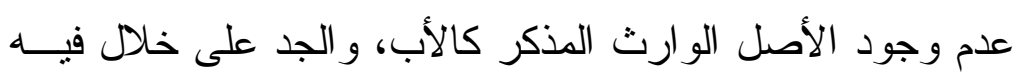
كما قلنا.

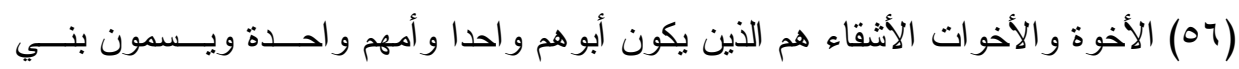

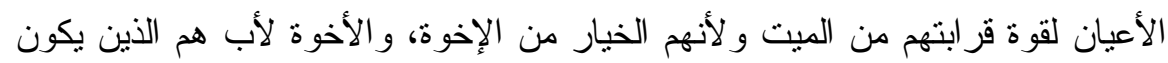

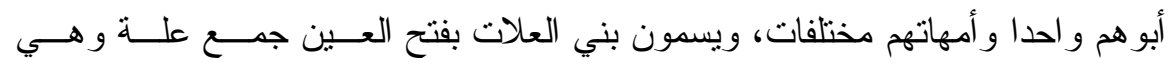

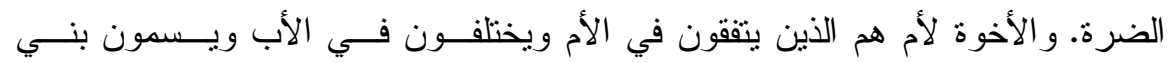

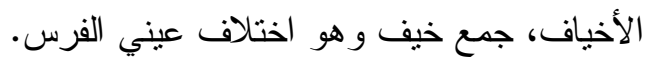


فإذا نوفيت عن زوج وأخت شقيقة وأم كان للزوج، النصف لعدم الفــرع

الو ارث، وللأخت الثقيقة النصف لانفر ادها و عدم وجود معصب لها و وعدم وجود من يحجبها. وللأم الثلث فرضا لعدم وجود الفرع الوارث و عدم وجود جمع من

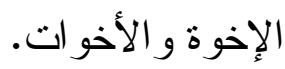

و إذا مات عن زوجة وأخت شقيقة وأم وعم كان للزوجة الربــع فرضــــا

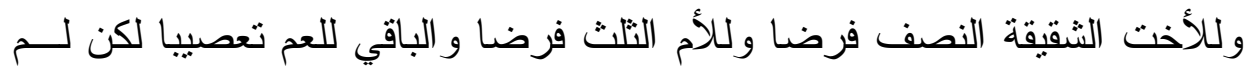
يق له شيء لأن الفروض قد استغرقت كل التركة.

الحالة الثانية: نرث الأختان الثقيقتان فأكثر التلنين عند عدم وجود أخ يعصبهن و لا فرع وارث مؤثث يعصبن معه كالبنت، وبنت الابن، و لا فرع وارث مذكر و لا أصل مذكر لأنهما يحجبان بهما.

فإذا نوفى عن أم وزوجة وشقيقتين كان للأم السدس فرضـا لوجود الأختــين وللزوجة الربع فرضا لعدم وجود الفرع الو ارث وللثققيقتين التلثنان فرضا. و إذا ماتت عن زوج وأربع شقيقات كان للزوج النصف فرضا وللثقيقات النتان فرضا يوزع بينهم بالتساوي. الحالة الثالثة التعصيب بالغير: وتثبت هذه الحالة للأخت الثقيقة أو الأكثــر، إذا

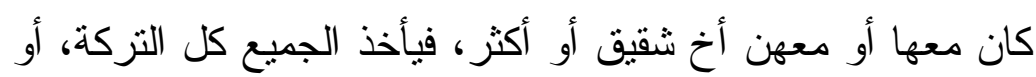




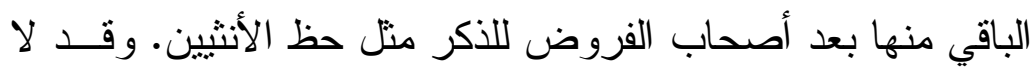
يأخذ شيئًا بالمرة إذا استغرقت الفروض كل الثركة.

فإذا مات عن أخ شقيق وأخت شقيقة كانت التزكة بينهما للــكر ضــف الأنثى فتأخذ الأخت ثلثها ويأخذ الأخ تلثاها.

و إذا مات عن أم و أخ شقيق و أخت شقيقة كان للأم السدس فرضـا لوجـود عدد من الأخوة و الباقي للأخ و الأخت للأكر ضعف وان الأنثى.

و إذا ماتت عن زوج وأم وبنتين و أخ شقيق وأخت شقيقة. كــان للــزوج الربع فرضا لوجود الفرع الو ارث، وللأم السدس فرضا لو وجود الفرع الــوارث،

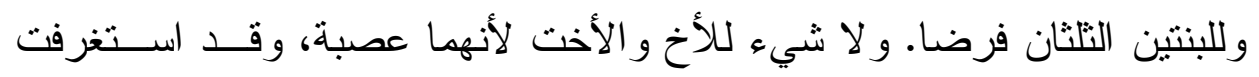

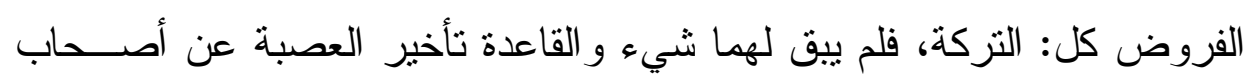

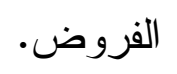

الحالة الرابعة التعصيب مع الغير: وتتبت هذه الحالة للثقيقة أو الثقيقات إذا كان

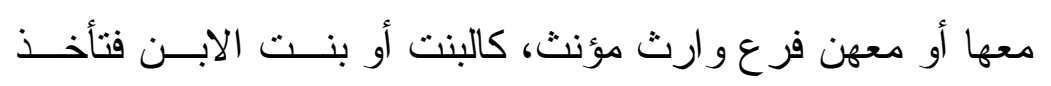

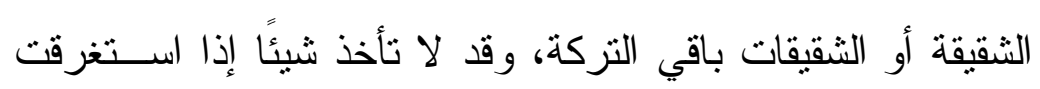

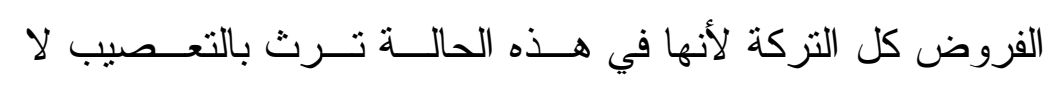
بالفرض كالحالة السابقة. 


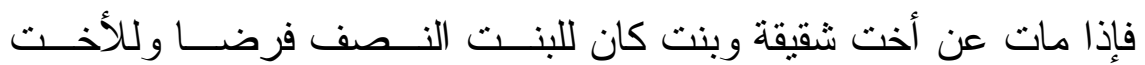

الثقيقة الباقي تعصيبا. و إذا مات عن بنتين و أختين شقيقتن كان للبنتين التلتــان وللأختين الباقي تعصيبا، و إذا مات عن بنت ابن وأختين شقيقتين كان لبنت الابن النصف فرضا وللأختين الباقي تعصيا.

و إذا ماتت عن زوج و أم وبنتين و أختين شقيقتين كان للزوج الربع فرضـــا لوجود الفرع الوارث. وللأم السدس فرضـا لنفس الــسبب ولوجــود الــثقيقتنين وللبنتين الثلان فرضا، و لا شيء للأختين الثقيقتنين لأنهما عصبة لم يبـق لهــا شيء، إذ الفروض قد استغرقت جميع التركة.

الحالة الخامسة: حجبها أو حجبهن سو اء كان معها أو معهـن أخ شـقيق أو لا، وذللك بالفرع الو ارث الدذكر كالابن وابــن الابــن و إن نــزل، وبالأصل الوارث المذكر كالأب باتفاق وبالجد الــصحيح عنــــ

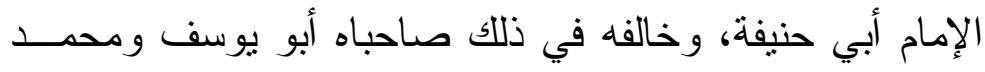

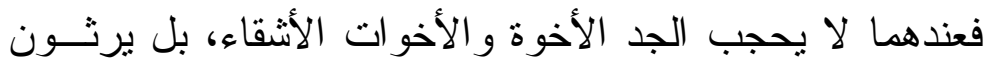
معه وهو أيضًا مذهب جمهور الفقهاء وقد أخذ قانون المواريث

$$
\text { بمذهب الصاحبين. }
$$

فإذا توفى عن زوجة وأم و أب وأخت شقيقة كان للزوجة الربــع فرضـــا

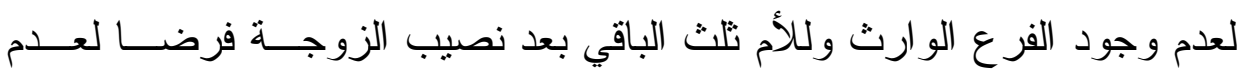


وجود الفرع الوارث و عدم وجود الأخوة و الباقي لــلأب تعـصيبا، و لا شـيء للأخت الثقبقة لحجبها بالأب.

و إذا توفى عن زوجة وأم و ابن و أخ شقيق و أختين شقيقتين. كان للزوجـــة

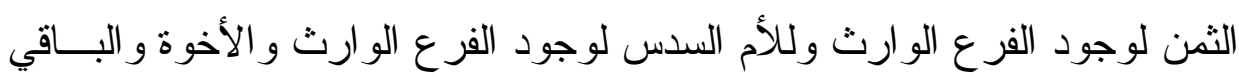

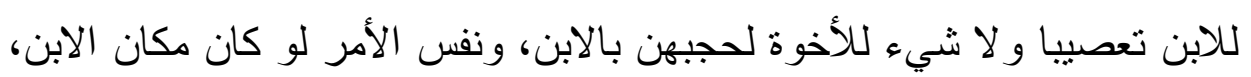
ابن ابن. - أدلة ميراث الأخوات الثقيقات:

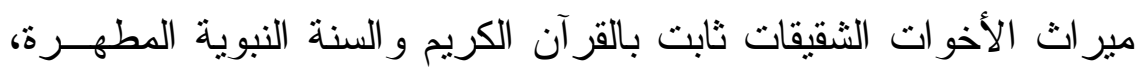

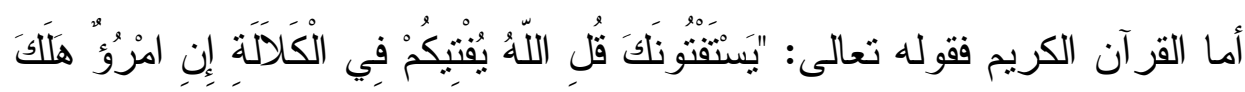

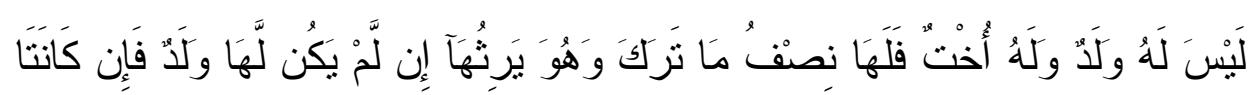

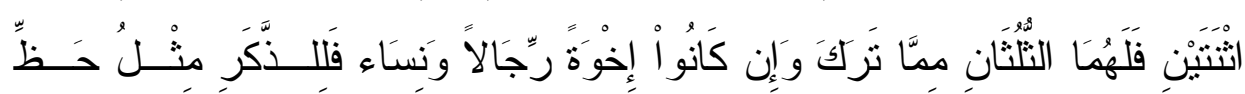

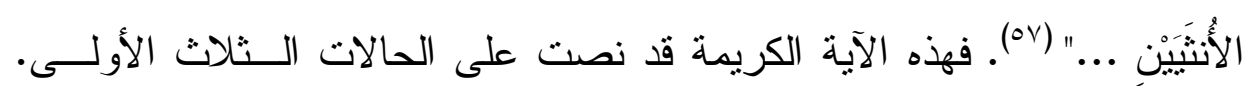

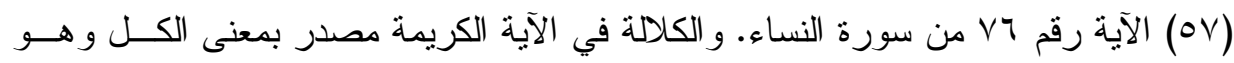

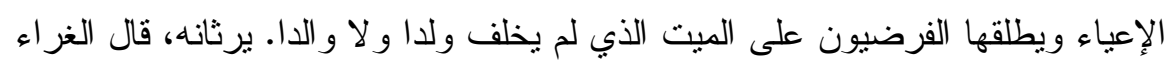

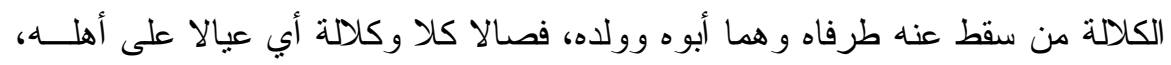

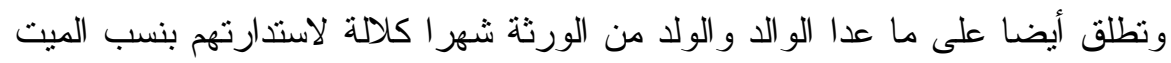

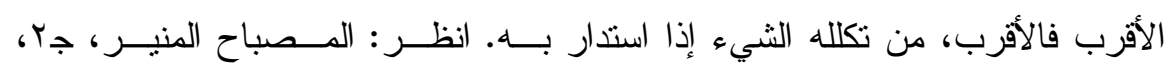

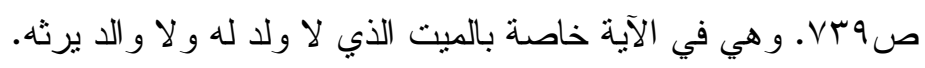

V مجلت البحوث القانونيت والإقتصاديت 
فقوله تعالى: "ليس له ولد وله أخت فلها نصف ما ترك" دليـل علــى اســتحقاق الأخت الثقيقة النصف عند انفر ادها.

وقوله تعالى: "فإن كانتا اثثتين فلهما التنثان مما ترك" دليل على اســتحقاق الأختين الثقيقتين الثلثين فرضا. وقد يقال أن الآية دليل على ميــر اثل الأختــين لكنها لم تصرح بمير اث الأكثر من الاثتنين. ويجاب على ذلك بأن آية الأو لاد قد نصت على مير اث ما فوق البنتين، إذ تقول: "فإن كن نساء فوق اثثتين فلهن ثلثا

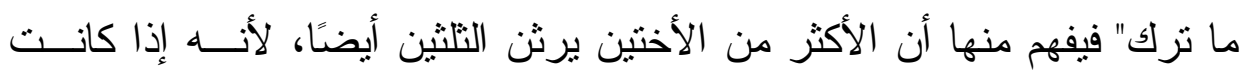

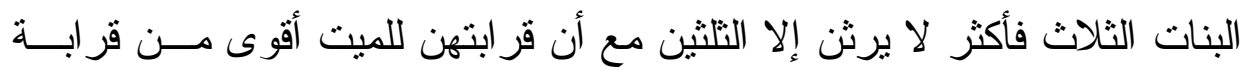
الأخوات فبالأولى لا يأخذ الأخوات أكثر من الثنثين، و لا يعقل أن يكون أقل من لهن

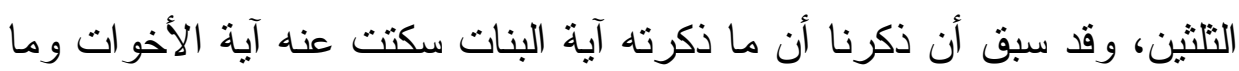
ذكرته آية الأخوات سكتت عنه أية البنات.

و أما قوله تعالى: "فإن كانو إخوة رجالا ونساء فللذكر منل حظ الأنثين"،

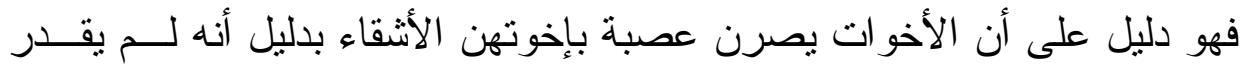

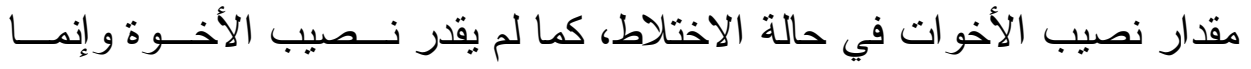

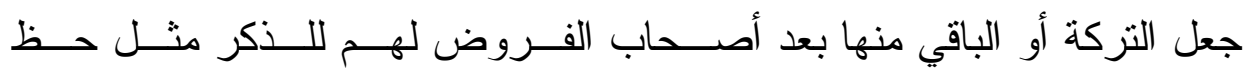

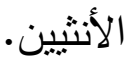




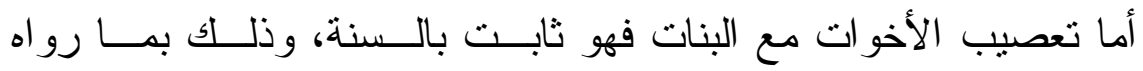

البخاري ومسلم وغير هما من أن النبي صلى الله عليه وسلم قضى في بنت وبنت

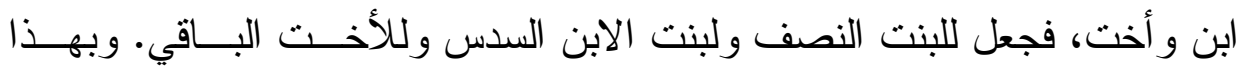
قضى عبد الله بن مسعود عندما عرضت عليه مسألة فيها بنت وبنت ابن وأخــت

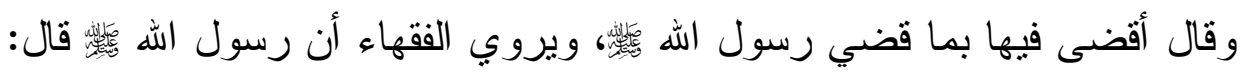
"اجعلو ا الأخوات مع البنات عصبة" و أما حجبهن بالابن و ابنه فهو مسـتفاد مسن قوله تعالى: "ليس له ولد وله أخت" حيث يدل على أن توريث الأخ مــن أختــهـ

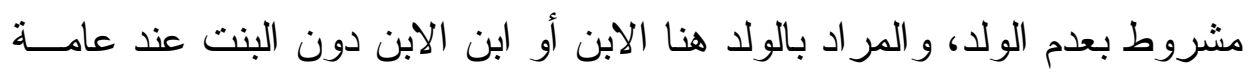

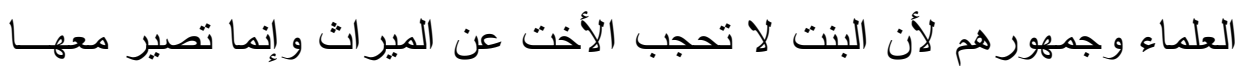

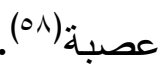

و أما حجبهن بالأب فلقوله تعالى : "قل الله يفتيكم في الكلالة"، و الكلالة هـــو

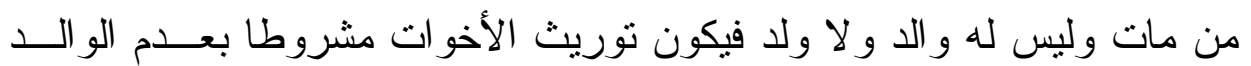

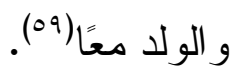

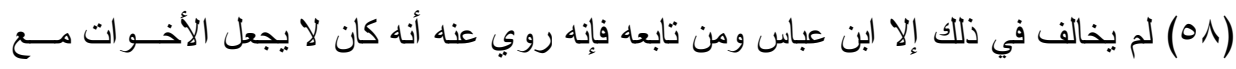

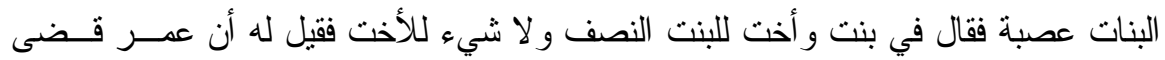

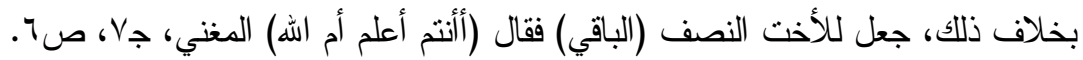

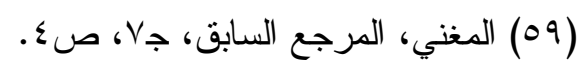

Vملتم البحوث القانونيت والإقتصاديت 


\section{سادسًا: أحوال ميراث الأخوات لأب:}

الأخت لأب هي الأخت التي تثتارك الميت في أبيه دون أمه، وهي تقــوم

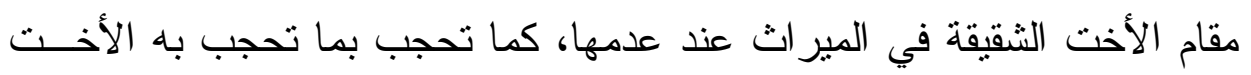

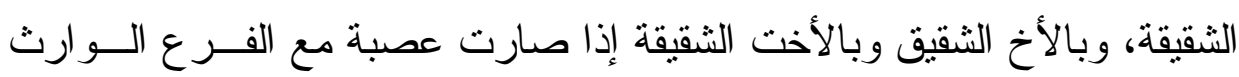
المؤنث و إليك أحو ال الأخت لأب:

الحالة الأولى: ترث الو احدة من الأخوات لأب النصف عنــــ انفر ادهــا، وعــدم

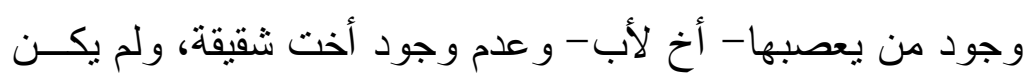

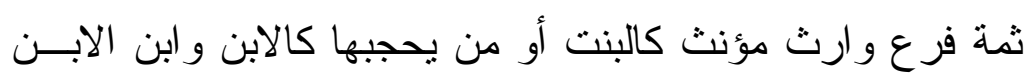

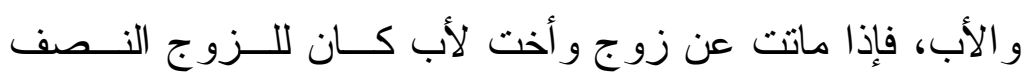

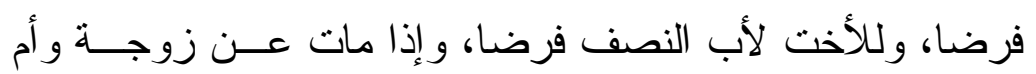

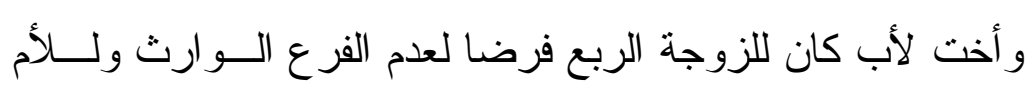

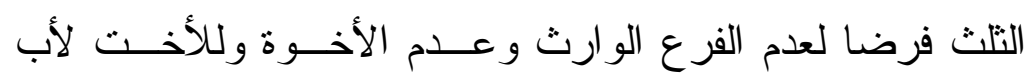
النصف فرضا لانفر ادها وعدم وجود من يعصبها أو يحجبها.

الحالة الثانية: ترث الاثثتان فأكثر الثلثين بشرط عـدم وجــود مــن يعـصبهن أو يحجبهن.

فإذا مات وترك زوجة وأختين لأب و أم كان للزوجة الربع فرضـــا لعــدم

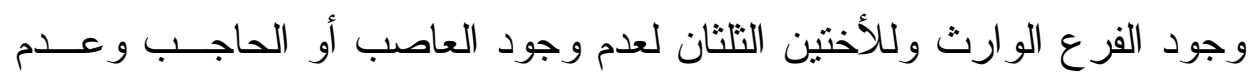
وجود الثقيقة أو الثقيقات و لأم السدس لتعدد الأخوة. 
و إذا مات عن زوجة وأم و أخت لأم و أختين لأب كـان للزوجــة الربـع

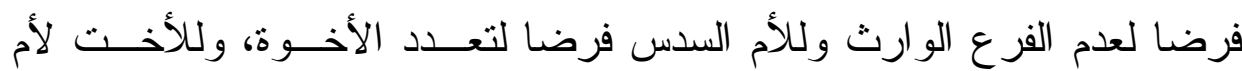

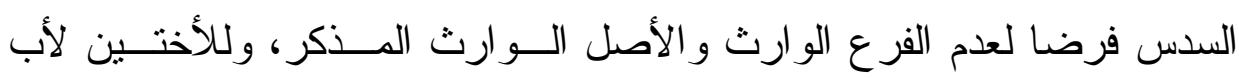
التلثان فرضا لعدم وجود معصب أو حاجب و عدم وجود شقيقة أو شقيقات.

الحالة الثالثة: ترث الو احدة و الأكثر من الأخوات لأب السدس فرضا، إذا كــان

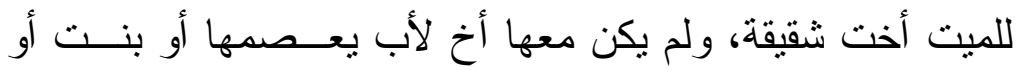

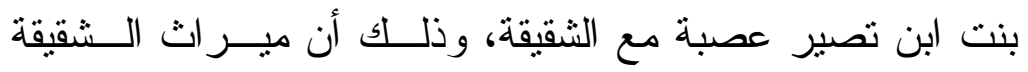

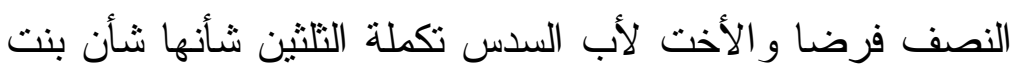

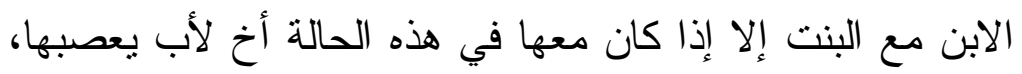
فترث معه بالتعصيب.

فإذا مات عن زوجة و أخت شقيقة وأخت لأب كان للزوجة الربـع لعـدم

الفرع الو ارث، للأخت لأب السدس تكملة التلثين ولو كان بـــل الأخــت ثــلاث أخوات مثلا لاثشتركن في هذا السدس بالسوية. و الباقي يرد على الأخت الــشقيقة و الأخو ات لأب بنسبة سهامهن.

و إذا مات عن أم وأخت شقيقة وأخ لأب و أخت لأب كان لــلأم الــسـس

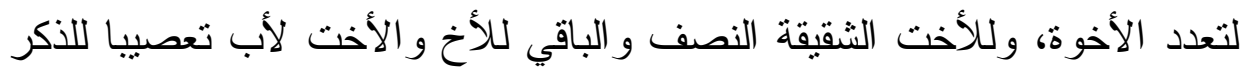

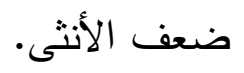


و إذا ماتت عن زوج وبنت ابن و أخت شقيقة و أخت لأب كان للزوج الربع

فرضا لوجود الفرع الوارث، ولبنت الابن النصف فرضا وللأخت الثقيقة الباقي

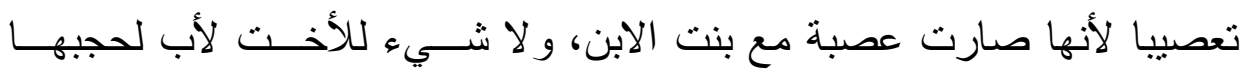

$$
\text { بالثقيقة بعد أن صارت عصبة. }
$$

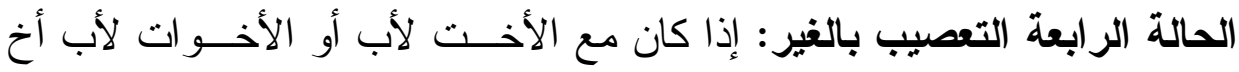

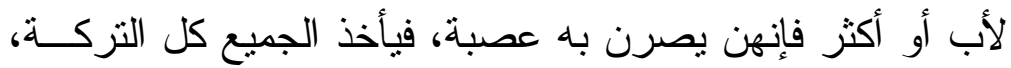
إذا انفردوا بها ويأخذون الباقي بعد أصحاب الفـروض، للـــكر

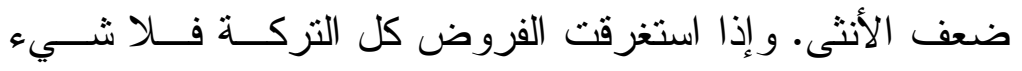

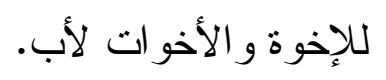

فإذا مات عن ورثنة هم: أخوين لأب وثناثل أخوات لأب، كانـــت التركــة لهم للأكر ضعف الأثنى. - م.

و إذا مات عن زوجة وأم و أخ لأب و أخت لأب كان للزوجة الربع وولــأم

$$
\text { السدس لتعدد الأخوة و الباقي للأخ و الأخت لأب تعصيبا. }
$$

و إذا مانت عن زوج و أم وأخت شقيقة وأخ لأب و أخت لأب كان للــزوج النصف وللأم السدس لتعدد الأخوة وللثقيقة النصف أما الأخ لأب و الأخت لأب

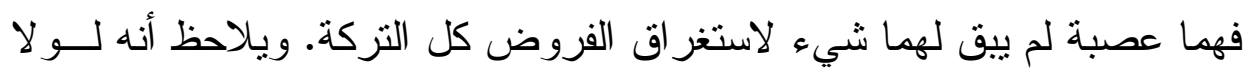


الأخ في هذا المثال لاستحقت الأخت لأب السدس تكملة لتلثين، ولذلك يُطلق علبه الأخ المشئوم إذ لو لاه لورثت الأخت لأب السدس.

الحالة الخامسة: التعصيب مع الغير: وذللك إذا كان مع الأخت لأب أو الأخوات لأب فرع و ارث مؤنث- بنت أو بنت ابن و إن نزل. بشرط عدم

وجود من يحجبها أو يحجبهن. وفي هذه الحالة تأخــذ الأخــت

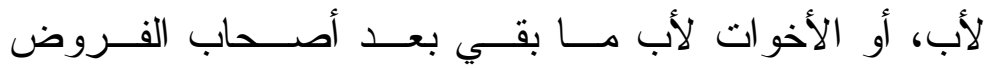
بالتعصيب، و إذا استغرقت الفروض كل التركة فلا يأخذن شيئًا. فإذا مات وترك زوجة وأما وبنتا و أختنن لأب، كان للزوجة الثمن لوجود

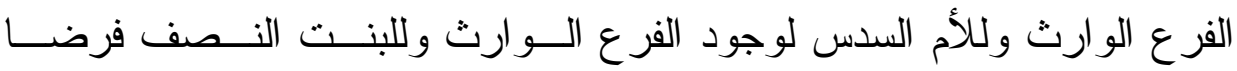
وللأختين لأب الباقي لأنهما صار ا عصبة مع البنت.

و إذا ماتت عن زوج وأم وبنتين وأخت لأب أخذ الزوج الربع وأخذت الأم

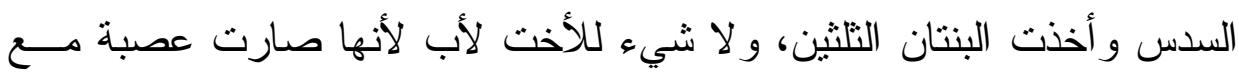
البنتين، ولم ييق لها شيء لاستغر اق الفروض كل التركة. الحالة السادة: تحجب الأخت لأب أو الأخوات في الأحوال الآتية: أ - تحجب الأخت لأب أو الأخوات لأب عـن الميــر اث بــالأختين الــشقيقتين أو الأكثر إلا إذا كان معها أو معهن أخ لأب يصرن به عصبة، فإذا لم يكن 
معها أو معهن أخ لأب فلا يرثن شيئًا لاســنيفاء الـشقيقتين أو الـشقيقات

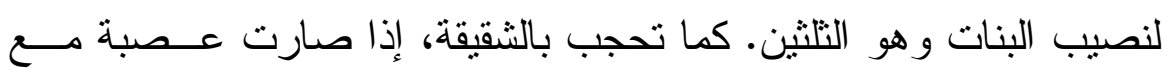

$$
\text { البنت أو بنت الابن سو اءو وجد معها أخ لأب أو لا. }
$$

فإذا مات عن أختين شقيقتين و أخت لأب و أخ لأب أخذت الثقيقتان التلثين و أخذت الأخت لأب و الأخ لأب الباقي تعصيبا للأكر ضعف الأنثى. و إذا مسات عن أخت شقيقة وبنت وبنت ابن و أخت لأب كان للبنت النصف ولبنــت الابــن

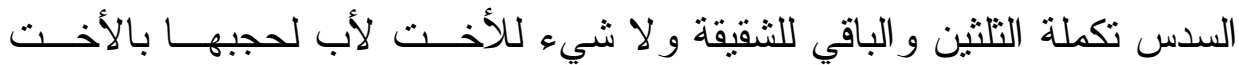
الثقيقة لما صارت عصبة مع البنت.

ب- تحجب الأخت أو الأخوات لأب بالأخ الثقيق، فإذا توفى عـن زوجــة وأم

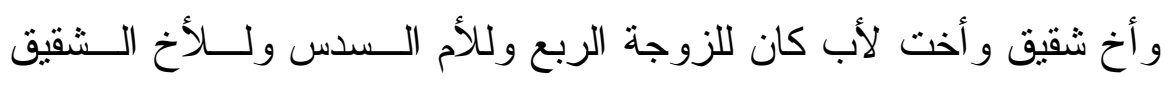
الباقي تعصيبا و لا شيء للأخت لأب لحجبها بالأخ الثقيق. ج- تعجب الأخت لأب أو الأخوات لأب بالفرع الوارث المذكر كــالابن وابـن الابن و إن نزل كما تحجب أيضًا بالأب، أما الجد فتحجب به لهاب عند أبي حنيفة خلافا للصاحبين وجمهور الفقهاء ما سبق القول. فإذا مات عن ابن، و أم وزوجة وأخت لأب فــلا ميـــر اث للأخـــت لأب لحجبها بالابن ونفس الحكم لو كان بدل الابن، ابن الابن. 
و إذا مات عن أب وأم وأخت لأب فلا مير اث للأخت لحجبها بالأب هـــا

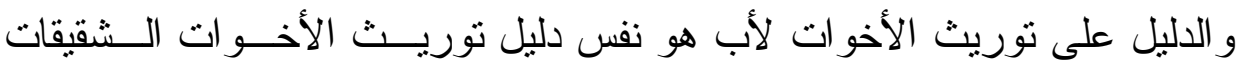
بالنسبة للحالات التي يشتركن فيها وهي استحقاق النصف، واسـتحقاق النلتهين

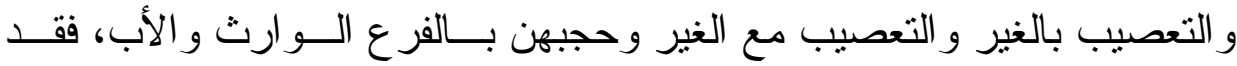

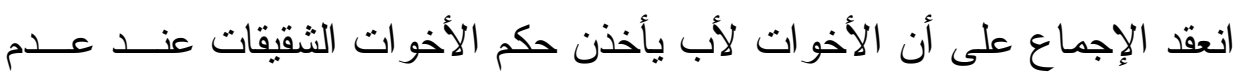
وجودهن كما يأخذ بنات الابن حكم البنات عند عدم وجودهن. ودليـلـل ميــراث الأخت لأب السدس مع الأخت الثقيقة القياس على بنت الابن مع البنت.

و أما حجبها بالأخ الثقيق فلما رو اه أحمد و التزمذي عن علي رضـي اله

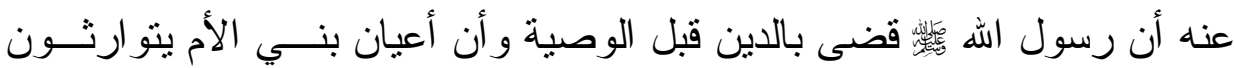

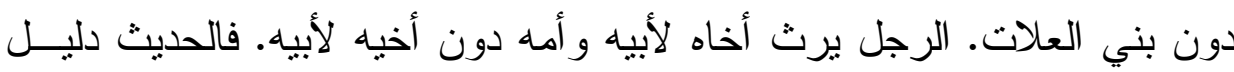
على تقديم الأخ الثقيق على الأخ لأب و الأخت لأب، كما أن الأخ الثقيق أقــوى

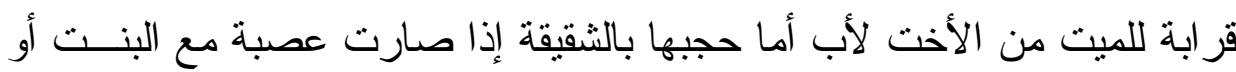
بنت الابن، فلأن الثقبقة في هذه الحالة تصير كالأخ الثقيق. سابعًا: أحوال ميراث الأخوة لأم وحكم اثشتر اكهم مع الأثثقاء:

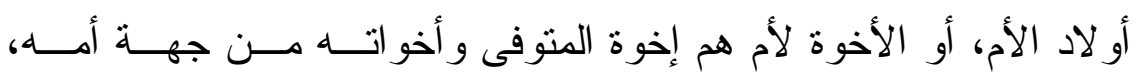
ويسمون بني الأخياف، وهم لا يرثون إلا بالفرض ويختلف فرضهم تبعا للانفر اد 
و التعدد، و لا يرثون مع الفرع الو ارث مطلقا مذكر ا كان أو مؤنثا، كما لا يرثون

$$
\text { مع الأصل الو ارث الدذكر كالأب و الجد لأب و وإن علا. }
$$

والإخوة والأخوات لأم لهم في الميراث حالات ثلاث:

الحالة الأولى: السدس فرضا، للو احد منهم ذكر ا كان أو أنثى بشرط عدم وجــود

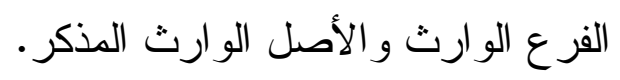

فإذا مات وترك: أخًا شقيقا، وأخًا أو أخت الأم. كان للأخ أو الأخت لأم

السدس فرضا، و الباقي للأخ الثقيق تعصيبا.

الحالة الثانية: التلث للأخوة والأخوات لأم إذا كانوا أكثر من واحد سواء كــانو ا

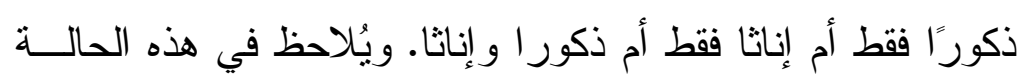

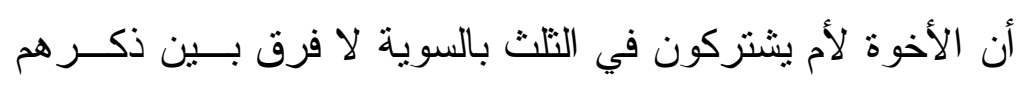

$$
\text { وأنثاهم. }
$$

فإذا مات وترك زوجة وأما، وثلاثة أخوة لأم:

كان للزوجة الربع وللأم السدس فرضا لتعدد الأخوة وللأخوة لأم التلـــث

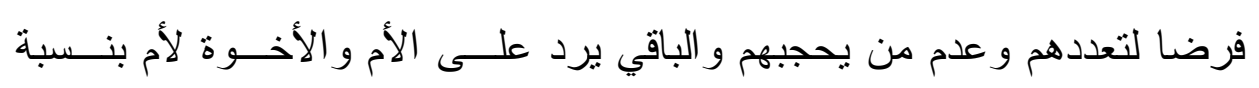
سهامهم. 
فإن للزوج النصف، وللأم السدس وللأخـــت و الأخ لأم التلـــث فرضـــا، لتعددهم، يقسم بينهما بالسوية لا فرق بين الذكر و الأنثى.

الحالة الثالثة: يحجب الإخوة لأم عن المير اث بالفر ع الوارث مطلقا، ذكر ا كــان أو أنثى، وبالأب و الجد أبي الأب (الجد الصحيح) و إن علا.

فإذا مات عن زوجة و أم وبنت و أخ لأم. كان للزوجة الثمن وللأم السدس

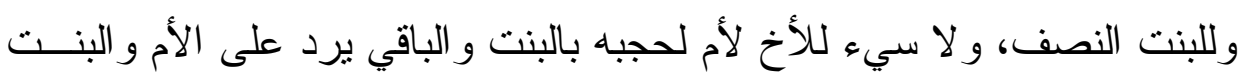
بنسبة سهامهما. و إذا ماتت عن زوج و ابن وأخ لأم وأخت لأم.

كان للزوج الربع فرضا لوجود الابن و الباقي للابن تعـصيبا ولا شــيء للأخ و الأخت لأم لحجبهما بالابن. و إذا مات عن أب وأم وثلاثة أخوة لأم. كان للأم السدس فرضا وللأب الباقي تعصيبا و لاشيء للأخوة لأم لحجبهم

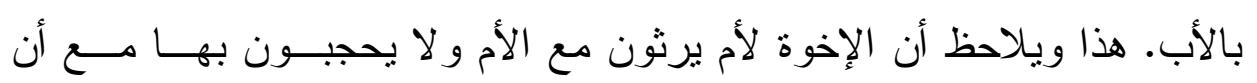

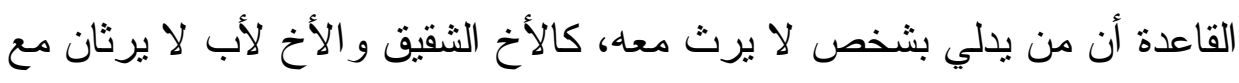

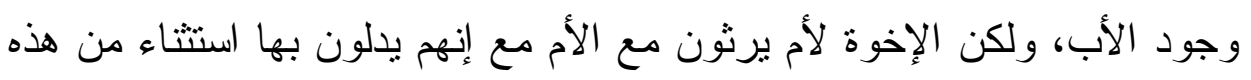


القاعدة العامة، و الحكمة في استثنائهم أن الأم لو حجبتهم لوقع علـيهم وحـــهم

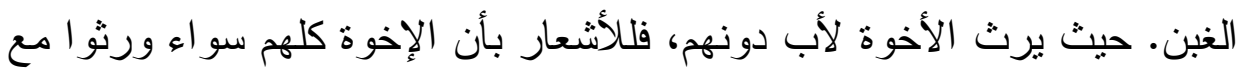
الأم وحجبو ا جميعا بالأب.

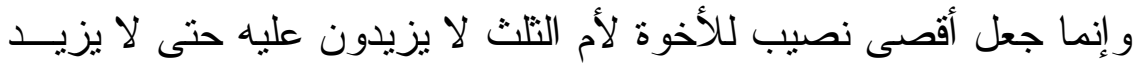

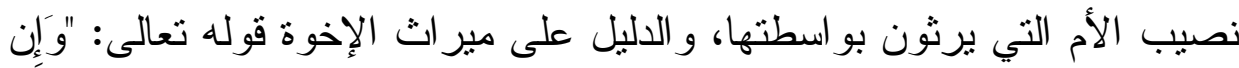

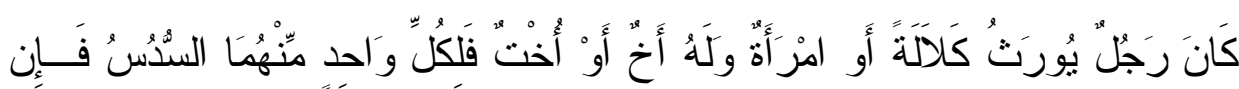

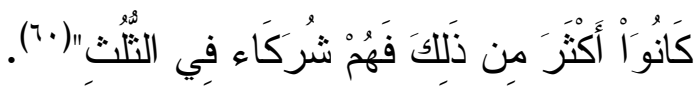
فقد أجمع العلماء على أن المر اد بالأخ و الأخت في الآية هو الأخ والأخـــ من الأم، وقد شرطت الآية لتوريثهم أن يكون الميت كلالة، وهو كما سبق، من لا

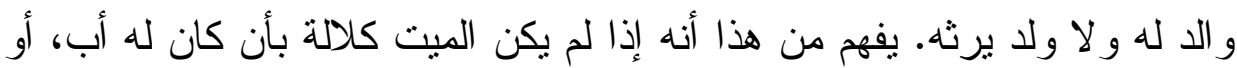
ابن فلا مير اث لهم ويحجبون في هذه الحالة بالأب أو الابن.

أما إذا كان الميت كلالة، وله أخ أو أخت من الأم استحق الموجود منهما

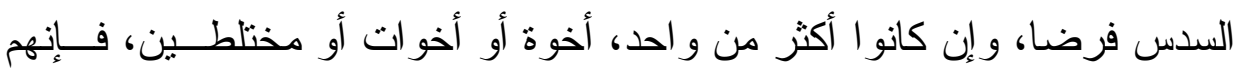
يستحقون الثلث يشتركون فيه بالسوية لا فرق بين ذكر و أنثى. ولذلك لأن الآيــة نصت على أنهم شركاء في التلث، و النزكة عند الإطلاق تقتضي المساو اة.

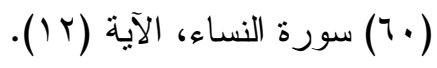

مجلتً البحوث القانونيتوالإقتصاديت 
ومن ناحية أخرى، فإن تفضيل الذكر على الأنثى إنما هو باعنبار العصبة

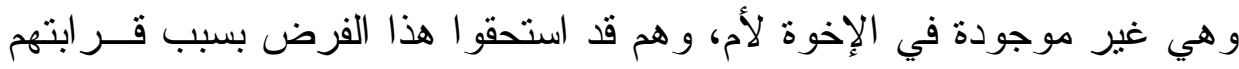

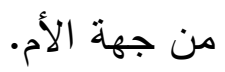

حكم اثثتر الك الإخوة لأم مع الإخوة والأخوات الأثقاء (المسألة المسشتركة): إذا

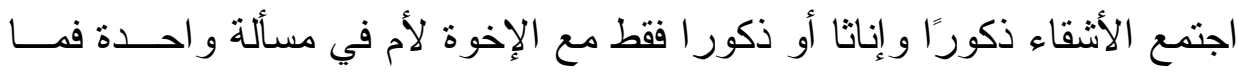

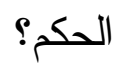

للإجابة عن هذا السؤال نقول: إن الإخوة الأثقاء ذكورًا و إناثا أو ذكــورا

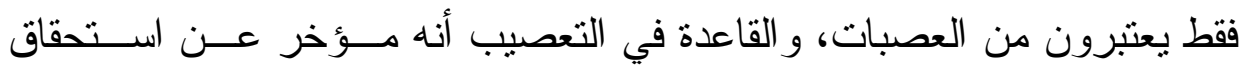

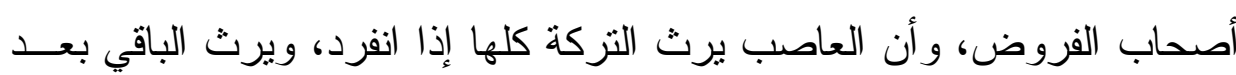
أصحاب الفروض، وقد لا يرث شيئًا إذا استغرقت الفروض كل النركة.

فالأخوة الأشقاء يرثثن بالتعصيب إذا كانو ا ذكورًا أو ذكورًا و إناثا ســـواء

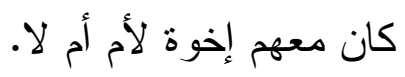

فإذا مات عن أخ لأم و أخ شقيق وأخت شقيقة أخذ الأخ لأم السدس و أخــــ الأخ الثقيق و الأخت الثقيقة الباقي تعصيبا للأكر ضعف الأنثى.

و إذا مات عن أخويت لأم وأخت لأم، وثلاثة إخوة أثنقاء، أخذ الأخوة لأم التلث فرضا و أخذ الأشقاء الباقي تعصيبا. 
و إذا مات عن زوجة وأخ لأم وأخت لأم، و أخوين شقيقين و أخت شـقـيقة

أخذت الزوجة الربع فرضا و أخذ الأخوة لأم التلث فرضا ولما وأخذ الأثــقاء البــاقي

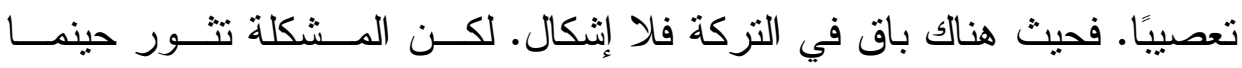

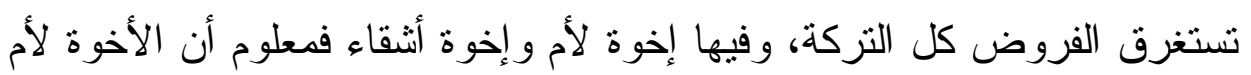
يرثون الثلث بالفرض حتما لعدم وجود من يحجبهم، أما الإخوة الأشقاء فلن ييقى

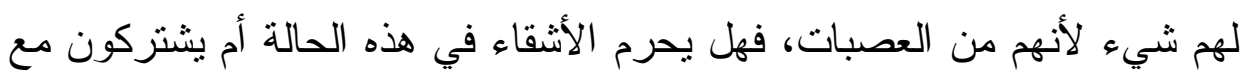

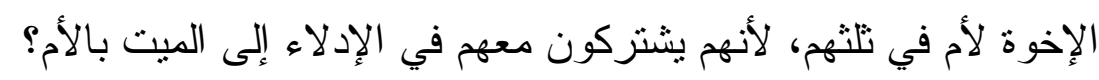

هذه الحالة تعرف في علم الفرائص بالمسألة المشتركة أو المشركة كمــــا

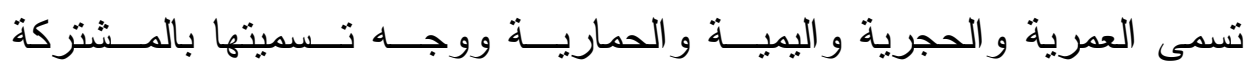

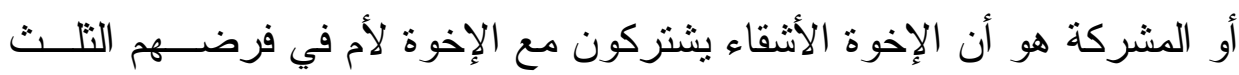
بإلغاء قر ابة الأب و اعتبار هم جميعا إخوة لم. ووجه تسميتها بالتسميات الأخرى، ما روي من أنه قد عرضت متل هذه المسألة على عمر بن الخطاب فقضى فيها

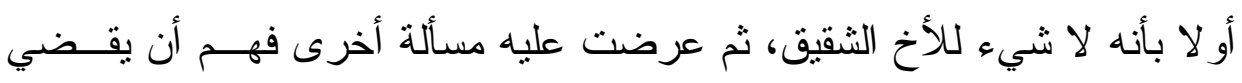

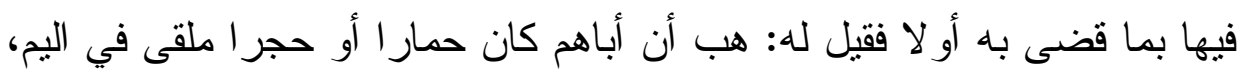

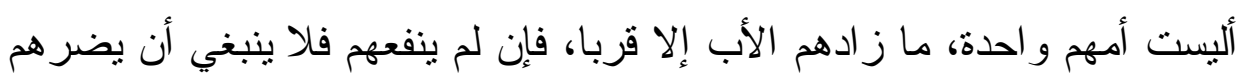
فقضى فيها عمر رضي الله عنه بالتشريك بيــنهم جميعـا باعتبــار هم جميعـا

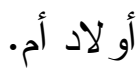


وصورة هذه المسألة: أن نتوفى زوجة عن: زوج وأم و أخــوين لأم وأخ

شقيق و أخت شقيقة أو أخوين شقيقين، أو جمع من الإخوة الأثقاء ذكور او إناتـا.

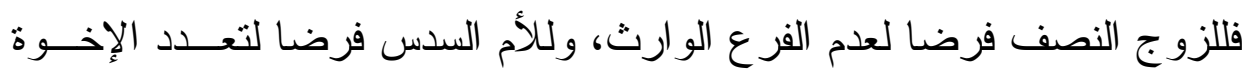

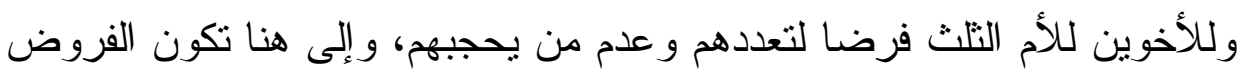
قد استغرقت كل التركة، ولم ييق للأثقاء ما يرثونه بالتعصيب.

ولكي نكون بصدد المسألة المشتركة فلا بـ من تحقق أمور أربعة هي:

$$
\begin{aligned}
& \text { 1 - أن يوجد صاحب نصف كالزو ج. } \\
& \text { r- أن يوجد صاحب سدس كالم أو الجدة الصحيحة عند عدم الأم. } \\
& \text { r- أن يوجد اثثان فأكثر من الأخوة لأم. } \\
& \text { ع - أن يوجد أخ شقيق أو أكثر. }
\end{aligned}
$$

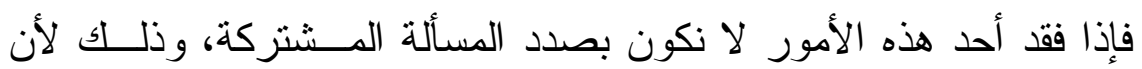

الفروض لن تستغرق التركة، فيرث الأشقاء بالتعصيب ولو سهما و احدا.

فإذا ماتت عن زوج و أخوين لأم و أخوين شقيقين. كان للــزوج النــصف وللأخوين لأم التلث وللثقيقين الباقي تعصيبا.

و إذا مات عن زوجة وأم و أخوين لأم و أخوين شقيقين. كان للزوجة الربع فرضا، وللأم السدس فرضا، وللأخوين النتل فرضا وللثقيقين الباقي تعصيبا. 


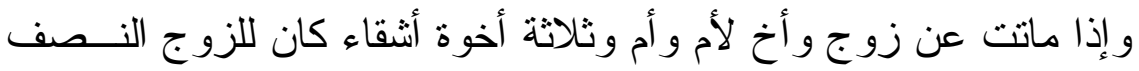

وللأخ لأم السدس لانفر اده، وللأم السدس لتعدد الإخوة وللأشقاء الباقي تعـصنيا.

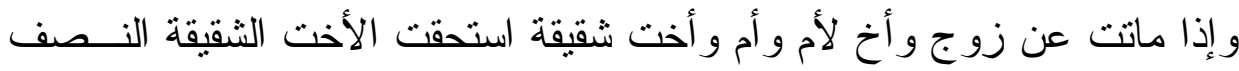

$$
\text { فرضا و عالت المسألة. }
$$

و إذا كان بدل الأشقاء أخ لأب أو أخوة لأب لا نكــون بـصدد الـــألة

$$
\text { المشتركة لعدم اتحادهم في الأب لا بالأم. }
$$

\section{هذا وقد اختلف الفقهاء حول المسألة المشتركة:}

فذهب بعض الصحابة منهم علي و ابن مسعود و ابن عباس و أبــو موسـى

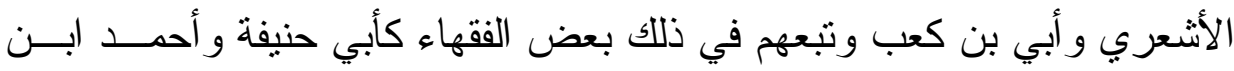

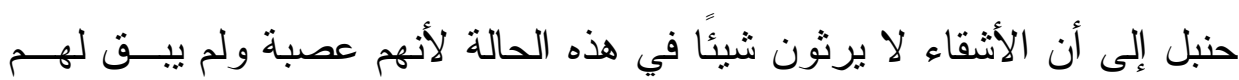

$$
\text { شيء. }
$$

و استتد هؤلاء في نفيهم التشريك بين الأثقاء والأخوة لأم على ما يلي:

1- أن في التشريك مخالفة لظاهر القر آن الكريم: حيث يقول تعالى: "و إن كسـان

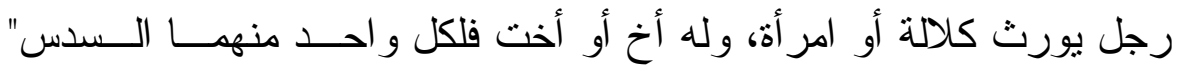
و التثريك يؤدي إلى عدم إعطاء كل و احد من الخ والأخــت لأم الـسدس.

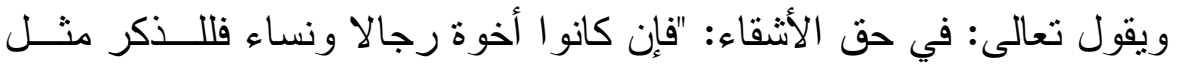

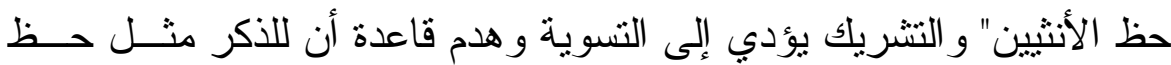

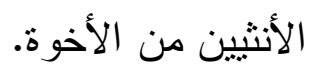




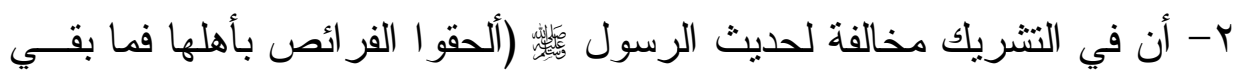
فالأولى رجل ذكر ) و التشريك يؤدي إلى عدم إلحاق الفر ائض بأهلها.

r- و أيضًا فإن الأخوة الأشقاء عصبة، فإذا لم ييق لهم شيء سقطو ا.

وبناء على هذا الر أي يستقل الأخوة لأم بفرضهم النظــث، ولا يـشـاركهم

الأخوة الأشقاء و إنما بسقطون لأنهم عصبة لم يبق لهم شيء.

وذهب البعض الآخر من الصحابة، كعمر بن الخطاب وعثمان بن عفــان

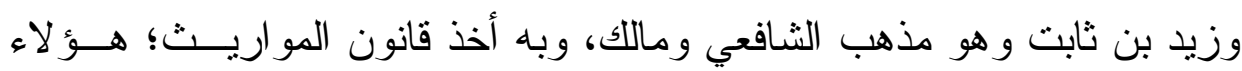

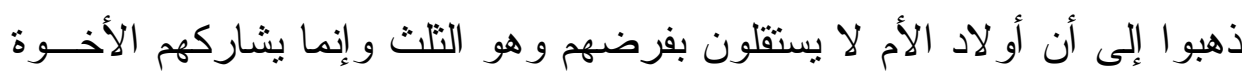

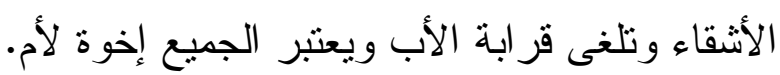

وقد استخل هؤلاء بأن الأخوة الأشتقاء قد نساووا مع الأخوة لأم في القرابة

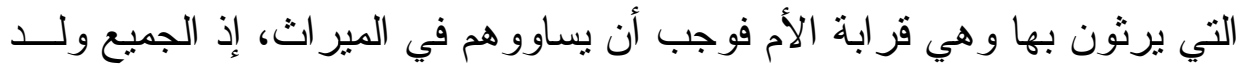

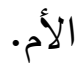

وقر ابة الأب إن لم تزدهم قربا واستحقاقا فلا ينبغـي أن تـسقطهم مـن

9) مجلت البحوث القانونيت والإقتصاديت 
ولذلك رد بعض الصحابة على عمر حينما هم بإسقاطهم للمــرة الثانيــة

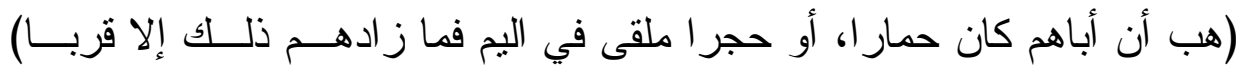
فتشرك بينهم في النتث.

و الذي يترجح هو الرأي الثاني الذي يقضي بالتشريك بين الأخوة الأثــقاء و الأخوة لم في فرض الثلث لأنه أقرب إلى العدالــة، لأن اســـــقاق الميــراث ير اعى فيه القرب وقوة الانتساب إلى الميت، وقد تساوى الأخوة الأثــقاء مــع الأخوة لأم في الانتساب إلى الميت بالأم، وزاد الأثقاء عليهم بالإدلاء إلى الميت

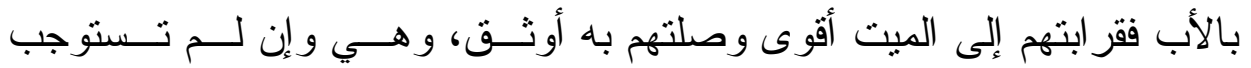
ترجيحهم على الإخوة لأم، فلا أقل من أن يتساوو ا معهم في توريثهم بقر ابة الأم. هذا وقد أخذ قانون المو اريث بمذهب المالكيــة و الـشـافعية فيمــــــــق بالمسألة المشتركة، فقد تتاولها في المادة العاثرة، إذ تتص على أنه: "لأو لاد الأم فرض السدس للو احد و التلث للأنثيين فأكثر ، ذكورهم و إناثهم في القسمة ســـواء، وفي الحالة الثانية، إذا استغرقت الفروض الثركة: يشارك أو لاد الأم الأخ الثقيق

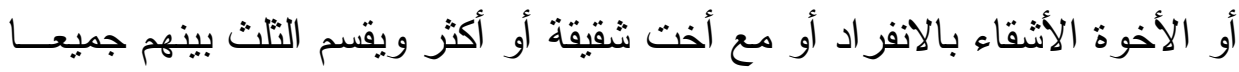
على الوجه المتقدم أبي لا فرق بين ذكرهم و أنثاهم في هذه الحالة.

وقد آثرنا هنا أن نذكر أحكام المسألة المشتركة لنتبت إلى أي مدى حرص

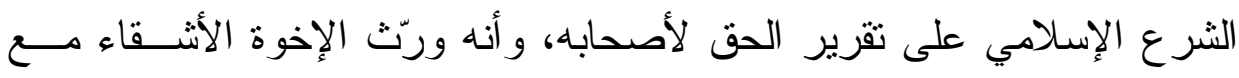


الأخوة للأم وجعلهم يشاركونهم في التلث لأن و اسطة الإدلاء بين الجميع وبـين

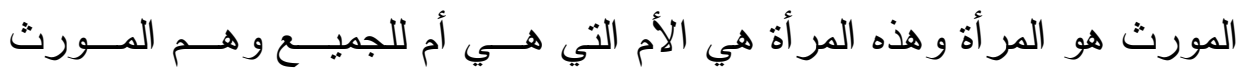

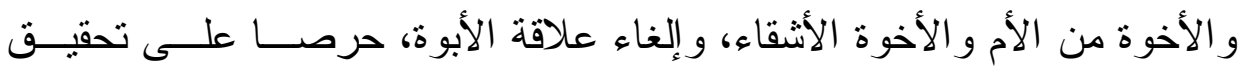

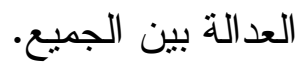

\section{ثامنًا: أحوال الزوجة أو الزوجات (عند التعدد): للزوجة في الميراث حالتان أيضًا:}

الحالة الأولى: أنها ترث الربع أي ربع نركة زوجها فرضـا إذا لــــــــن لهــذا الزوج فرع وارث بالفرض أو التعصيب سواء كان هــذا الفــرع

$$
\text { الو ارث من هذه الزوجة أو من غيرها. }
$$

فإذا توفى عن زوجة وأب أو أخ شقيق أو أخ لأب، فإن للزوجــة الربــع فرضا لعدم وجود الفرع الوارث، و الباقي للأب أو للأخ الــشقيق أو لــلأخ لأب تعصيبا. و إذا توفى عن زوجه وبنت بنت كان للزوجة الربع فرضـــا لأن بنــت

$$
\text { البنت ليست فرعا وارثا و إنما هي من ذوي الأرحام. }
$$

الحالة الثانية: أنها ترث الثمن فرضا أي ثمن ثركة زوجها إذا كان لهذا الــزوج فرع وارث بالفرض أو التعصيب سو اء كان هذا الفــر ع الـــوارث

$$
\text { من هذه الزوجة أو غير ها. }
$$

مجلة البحوث القانونيت والإقتصاديت 
فإذا توفى عن زوجة وابن كان للزوجة الــثن فرضــــــلابــن البـاقي

تعصيبا. و إذا توفى عن زوجة وبنت كان للزوجة الثمن فرضا وللبنت النـصف فرضا و الباقي ردا. و إذا توفى عن زوجة وابن وبنت كان للزوجة الثن، و الباقي للابن و البنت تعصيبا للأكر منل حظ الأنثيين.

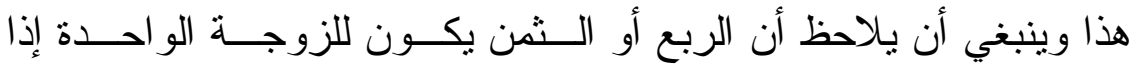
انفردت، وتتترك فيه الزوجات إذا تعددن يقتسمنه بالسوية. فإذا توفى عن ثلاث زوجات و أخ شقيق، فإن الزوجات الثناث يشتركن في الربــــ و إذا تـــوفى عـنـ زوجنت و ابن، فإن الزوجتين تشتركان في الثمن.

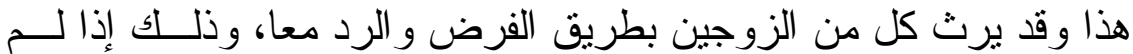
يكن للميت ورثثة من ذوي الفروض النسبة أو العصبة النسبية أو ذوي الأرحسام أما إذا وجد أحد هؤ لاء فلا يرثان إلا بالفرض فقط. و إذا توفى عن زوجته فقط أخذت النزركة كلها فرضا وردا، وإذا توفيــت عن زوجها فقط أخذ النزكة كلها فرضا وردا أيضًا.

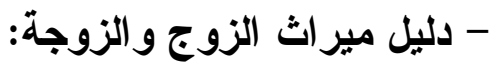

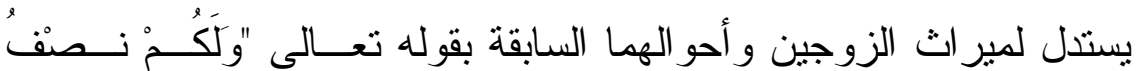

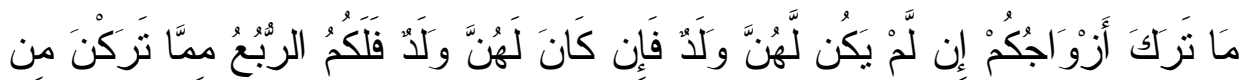




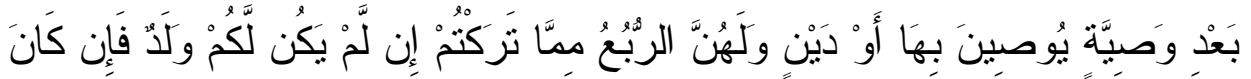

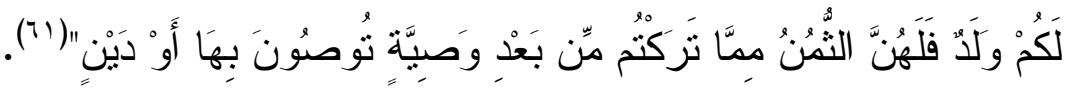
فهذه الآية الكريمة قد حصرت حالات كل مــن الــزوج و الزورجـة فـي المير اث فالزوج يرث النصف من زوجته إن لم يكن لها ولد، ويرث الربع مسن تركتها إن كان لها ولد سو اء كان هذا الولد منه أو من غيره. و الزوجــة تــرث الربع من تركة زوجها إن لم يكن لله ولد، وترث الثن من تركته إن كان له ولد

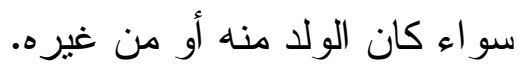

ولكن ما المر اد بالولد بالآية الكريمة الذي يؤثر على نــصيب كـلـل مـن الزوج و الزوجة بالنقصان فيرث الزوج الربع معه بدلا مــن النـصف، وتــرث الزوجة الثمن معه بدلا من الربع؟ اختلف الفقهاء في المر اد "بالولد" في آيات المواريث عموما و الذي يــؤثر على غيره من الورثة فيحجبه حجب حرمان أو نقصان. فذهب جمهور الفقهاء إلى أن المر اد "بالولد" الفــرع الــوارث بــالفرض

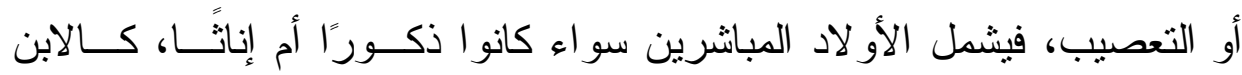
و البنت، كما يشمل أيضًا الفرع الذي ينوسط في النسب بينه وبين الميــت ذكــر 


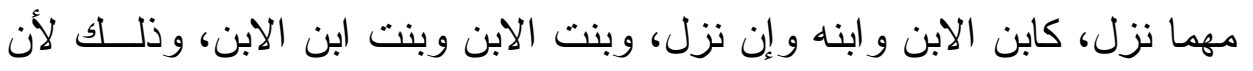
لفظ الولد ينتظم ولد الصلب ذكر ا كان أو أنثى وولد الابن و إن نزل، و لا يـشمل ولد البنت ذكر ا كان أو أنثى، ولذلك يقول الثناعر :

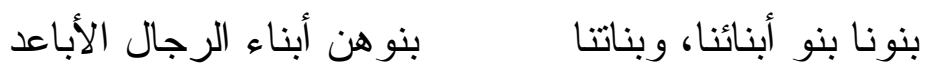

فالولد عند جمهور الفقهاء لا يصدق على الفرع الذي يتوسط نسبته إلـى

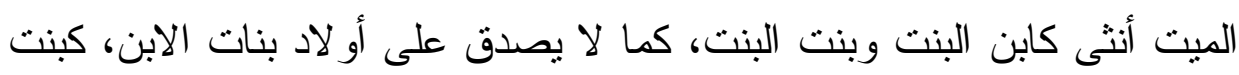

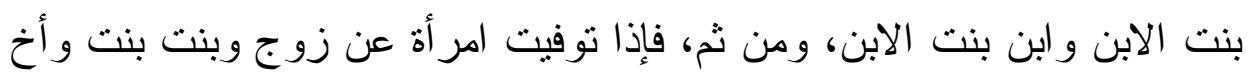

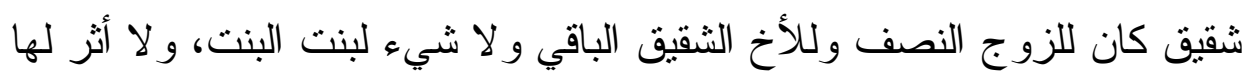
على نصيب الزوج، كما لا أثز لها على مير اث الأخ الثقيق. إذ لا يصدق عليها

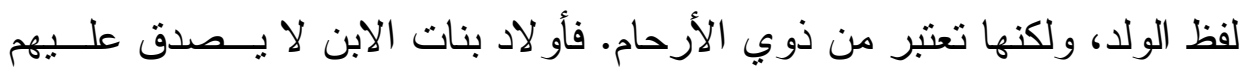

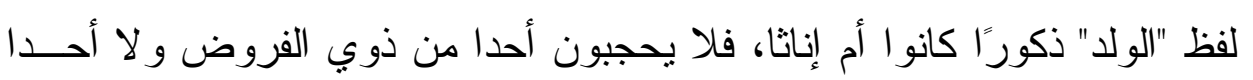

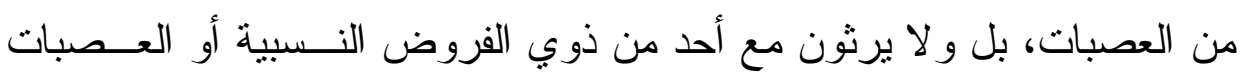
النسبية لأنهم يُعتبرون عند جمهور الفقهاء من ذوي الأرحام. وذهب الثيعة الإمامية إلى أن المر اد بالولد مطلق الذريــة، فكـلـ فـــــع

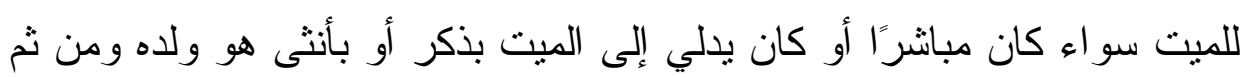
فإنه يؤثر على نصيب غيره من الورثة بالحجب حرمانا أو نقصانا. 


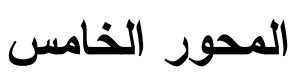

متى يكون ميراث المرأة على النصف من الرجل وهل يعتبر ذلك قاعدة عامة مطردة في ميراث المرأة

أولاً: متى ترث المرأة نصف نصيب الرجل؟

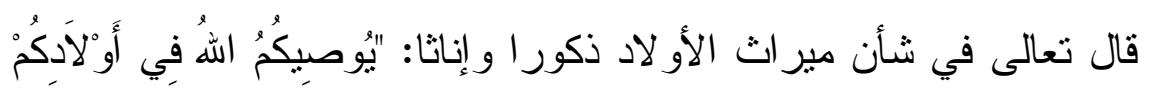

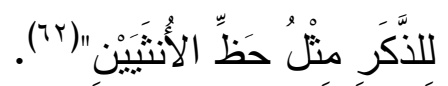

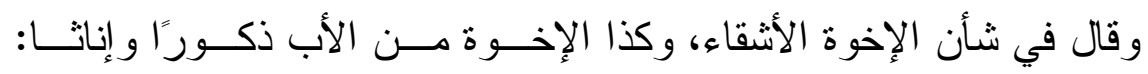

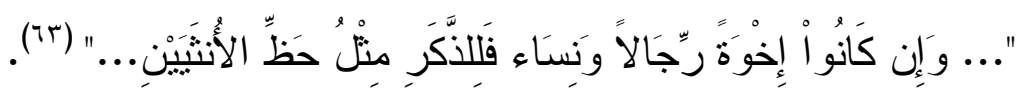

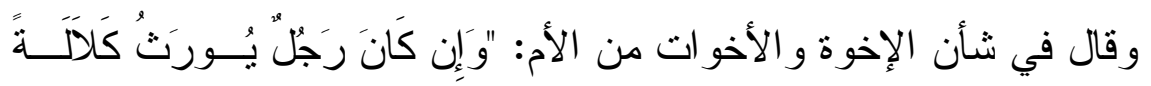

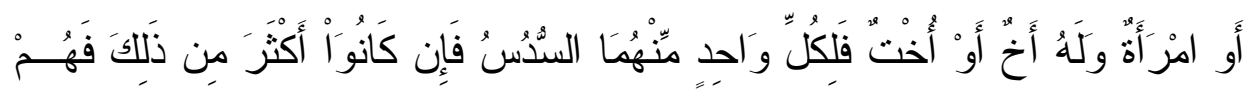

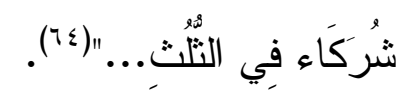

فالآية الأولى تدل على أنه إذا اجتمع ابن وبنت في تركة كان للابن مثـلـ

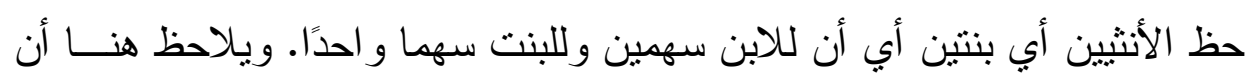

$$
\begin{aligned}
& \text { (ז) (Tورة النساء، الآية (I)). }
\end{aligned}
$$

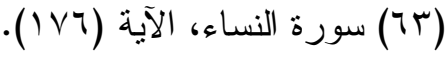

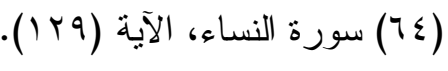

$$
\begin{aligned}
& \text { QV مجلت البحوث القانونيت والإقتصاديت }
\end{aligned}
$$


الابن و البنت بستويان في درجة القر ابة وقوتها، فهما من درجة قر ابـــة واحسـدة فكلاهما ولد للميت.

و الآية الثانية تدل على أنه إذا اجتمع أخ شقيق وأخت شـقـقة وكـــا الأخ

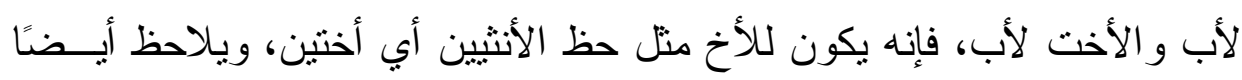

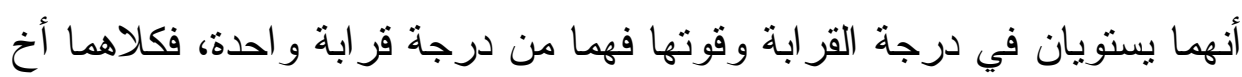
للميت.

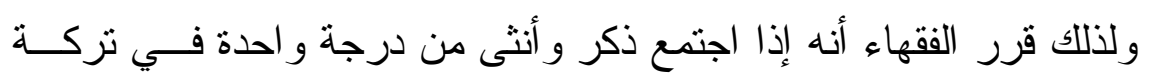
و احدة، كان للأكر ضعف الأنثى (70).

وفضلا عن أن الميراث في هذه الحالات يكون بالعصوبة فإن الحكمة كما

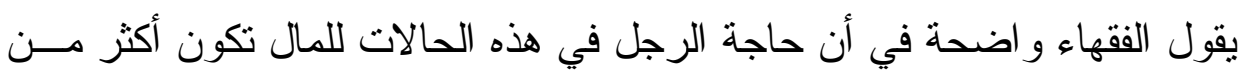

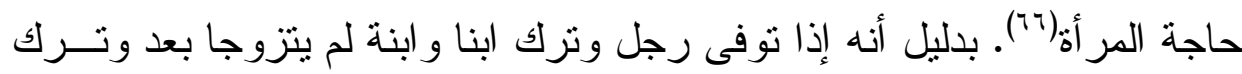

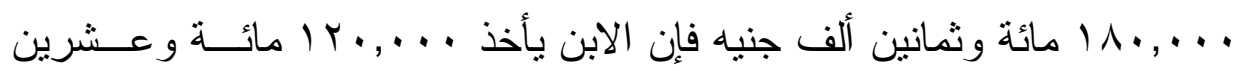

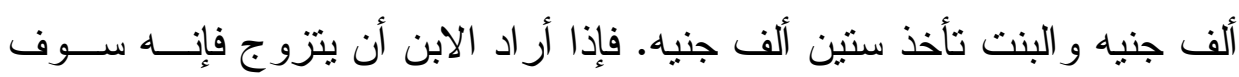

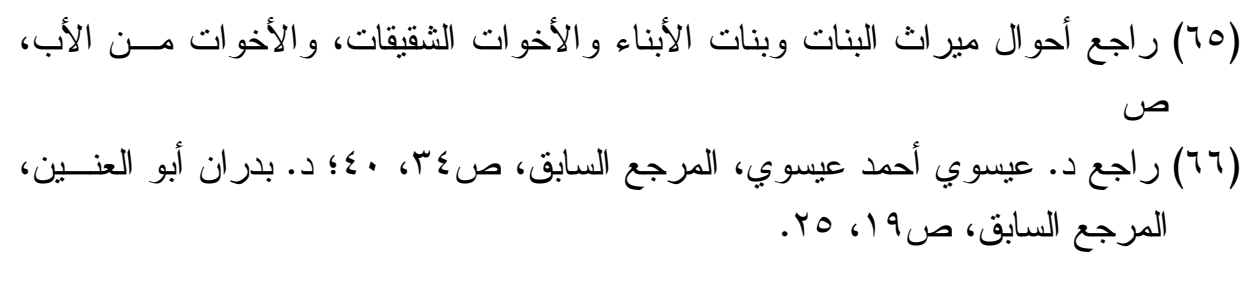
مجلتً البحوث القانونيتة والإقتصاديتة 91 
يدفع مهر ا وليكن .., . .0 خمسين ألف جنيه وسوف يجهز سكنا للزوجية بكلفة خمسين ألف فيتبقى له . .... . ب عشرون ألفا تكاد تكفي باقي تكاليف زو اجه. أما البنت فإذا أر ادت أن نتزوج فسوف تحصل على مهر وليكن . . ., .

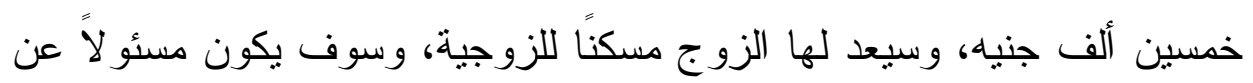

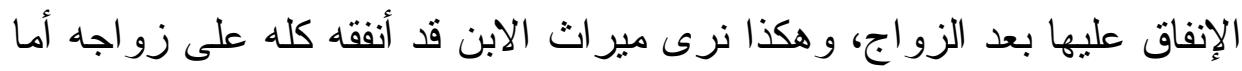
البنت فلم تتفق شيئًا من مير اثها.

هذا فضلا عن أن المرأة إذا لم تكن متزوجة فإن نفقتها تكون واجبة على

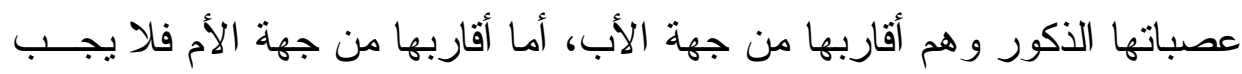

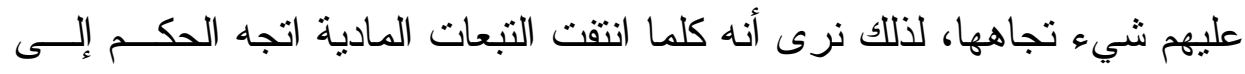

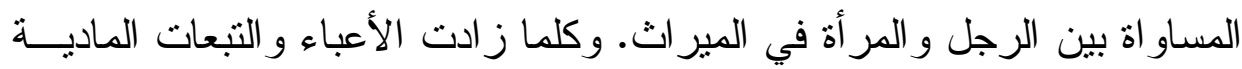
كان نصيب الرجل ضعف نصيب المر أة يتضح ذلك زيادة على ما سبق خاصنًا

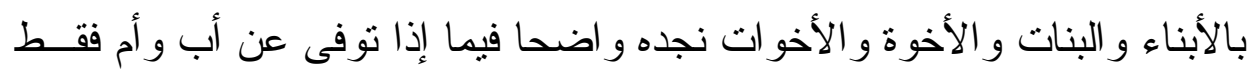

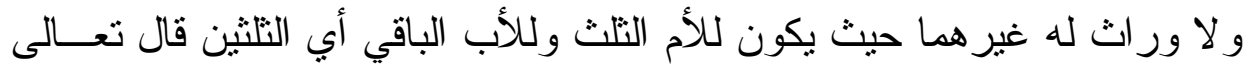

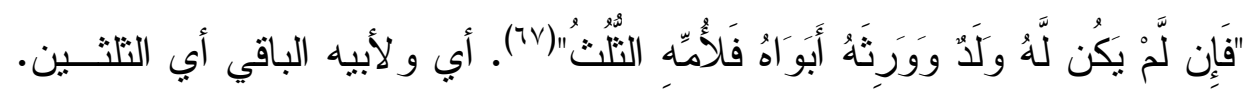

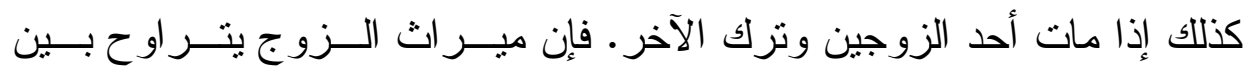
النصف و الربع تبعا لوجود فرع وارث من عدمه، و الزوجة بتز اوح مير اثها بين

(IV) (IV) (I) سورة النساء، الآية (1).

مجلم البحوث القانونيت والإقتصاديتة 
الربع و الثمن تبعًا لوجود الفرع الو ارث من عدمه، وهكذا نـسبة التقــاوت فـي

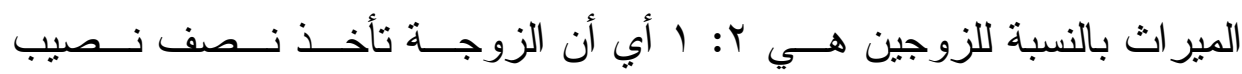

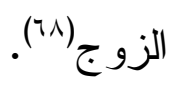

أما الآية التالية: فإنها تدل على أن الأخ من الأم الواحـــ يأخـــ الــسـس

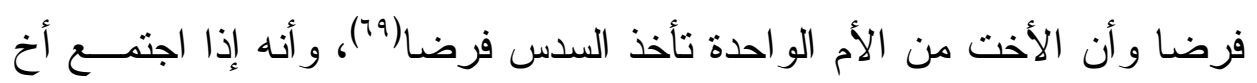

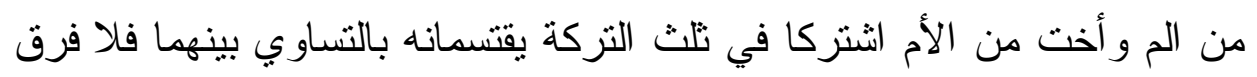

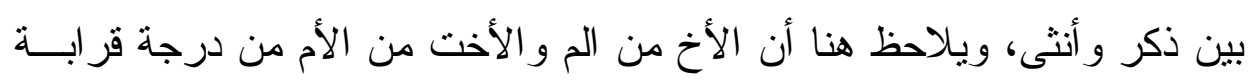

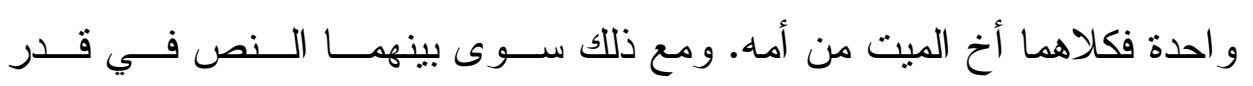

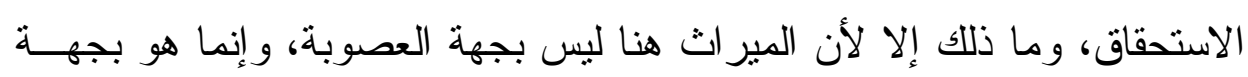

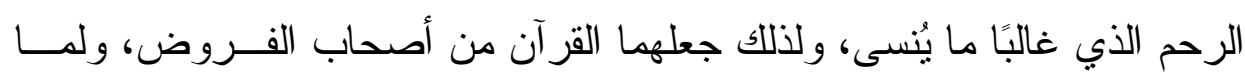

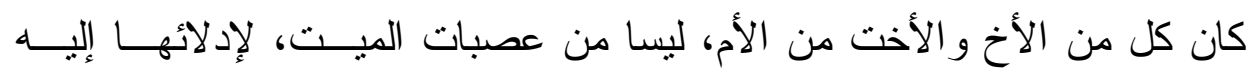
بو اسطة الأم وجدنا النص يسوي بينهما في قدر الاستحقاق.

ولذلك للا ر أينا في المسألة المشتركة تز احمًا بين الإخوة الأشقاء و الإخوة

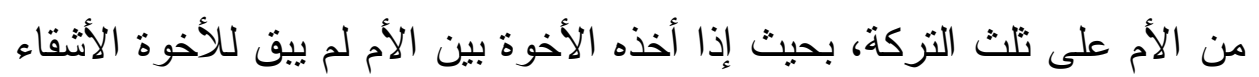

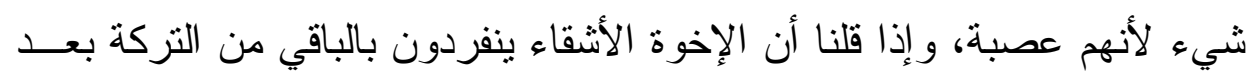


نصيب الزوج و الأم تكون قد خالفنا نص القرآن في الآية الكريمة، ونص حديث

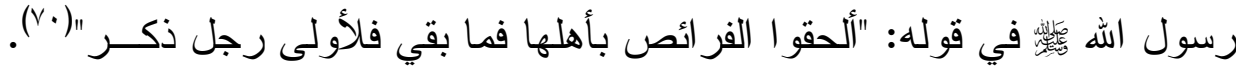

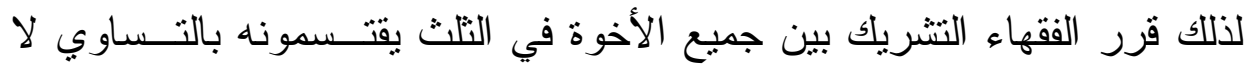
فرق بين أخ من الأم و أخ شقيق و لا فرق بين ذكر و أنثى.

لذللك تقرر أن قاعدة "للذكر مثل حظ الأنثيين "ليست قاعدة عامة مطــــدة في كل ذكر و أننى كما يحاول البعض أن يثيع، و إنما هي خاصــة بكــل ذكــر و أنثى من درجة قر ابة واحدة كالأبناء مع البنات و الأخوة الأنثقاء مع الأخــوات

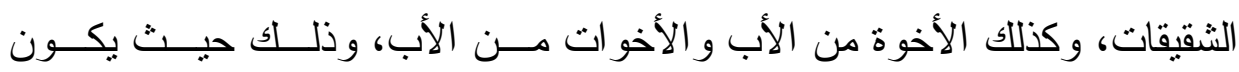

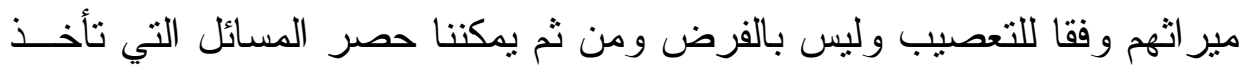
فيها نصف نصيب الرجل في أربع مسائل فقط وعلى سبيل الحصر وهي:

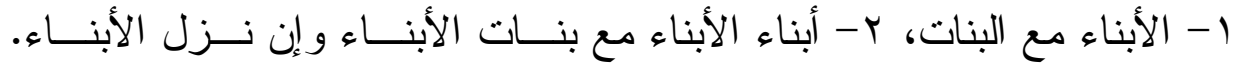
r- الإخوة الأشقاء مع الأخوات الثقيقات. ع - الإخوة من الأب مع الأخـــوات

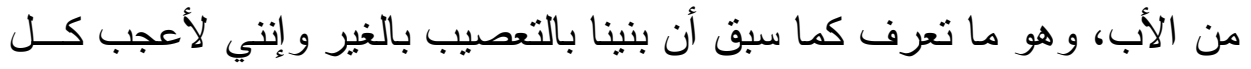
العجب ممن يلوون عنق الحقيقة، برددون بقصد أو بغير قصد، بــوعي أو دون

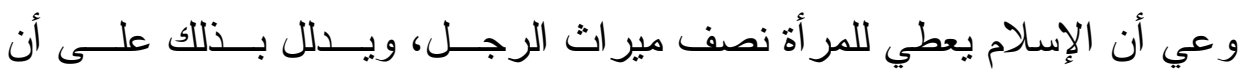

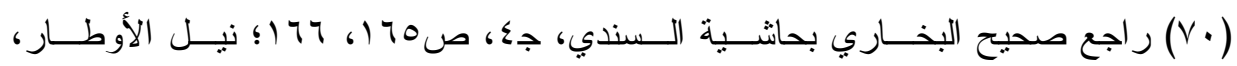

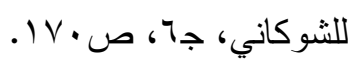

مجلة البحوث القانونيت والإقتصاديت 1. 
الإسلام ينظر إلى المرأة نظرة دونية وأنها أقل من الرجل!! و إنني لأرى الـــافع

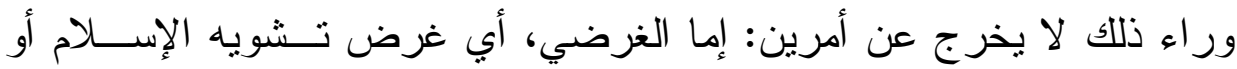
المرضي، الذي أصاب القلوب بجعل أصحابها يتعدون الإساءة إلـى الإســام

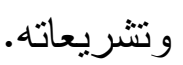

وللرد على أصحاب الغرض و المرض و الهوى نقول إن النطبيقات العملية لأحكام مير اث المر أة التي سبق أن أوردناها تسفر عن أن المر أة قد تأخذ نــصيبا بساوي نصيب الرجل، وقد تأخذ نصيبًا أكبر من نصيب الرجل، وقد ترث هـي لهي

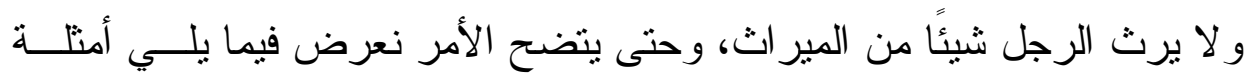
ونماذج تطبيقية على كل حالة من هذه الحالات:

أ - قد ترث المرأة نصيبًا يساوي نصيب الرجل في الميراث وذلك في الأمثــــة الآتية: ا- إذا نوفى عن أب وأم و ابن وبنت مثلا، نجد أن الأب يـرث الـسدس و الأم ترث السدس أيضًا و الابن و البنت يرثان الباقي. r- نفس الحكم إذا توفت عن أب و أم وبنت وزوج. r- نفس الحكم إذا نوفيت عن أب و أم وبنت وبنت ابن وزوج. ع - نفس الحكم إذا توفيت عن أب و أم وبنتين وزوج. 
0- إذا نوفيت عن زوج وأم و أخ لأم فإن الأخ لأم يأخذ السدس فرضا، ولو كان مكانه أختًا لأم لأخذت السدس، أيضًا

צ- إذا توفيت عن زوج وأم و أخ لأم و أخت لأم كان للأخ و الأخت من الأم ثلث التركة أي لكل و احد منهما سدس التركة لا فرق بين ذكر و أنثى. - V المسألة المشتركة كما لو توفيت عن زوج وأم وأختين لأم و أخ شقيق حيـث

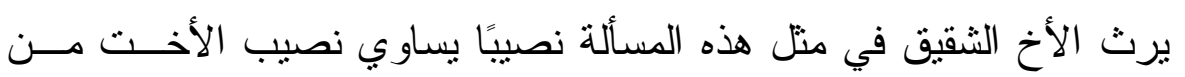

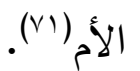

إضافة إلى ما سبق إذا توفى المورِّث عن وارث واحد ذكرًا كان أو أنثى

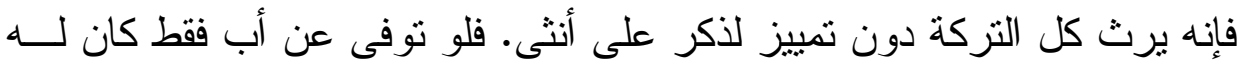

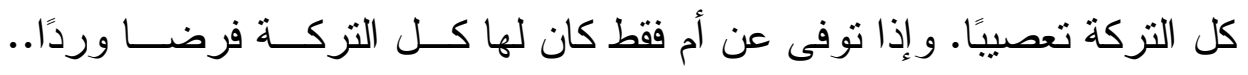
و هكذا لو توفى عن ابن واحد أو بنت واحدة، أو أخ واحد أو أخت و احدة فالحكم

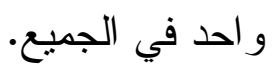

لذلك إذا توفى عن زوجة وبنت كان للزوجة الثمن فرضا وللبنت النصف فرضا و الباقي ردا، و إذا توفيت عن زوج و ابن كان للزوج الربع فرضا وللابـن

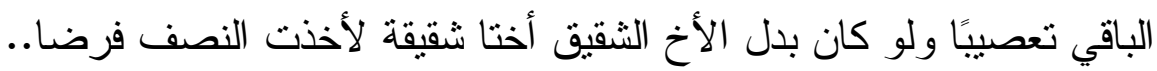

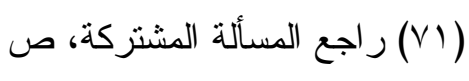

مجلت البحوث القانونيت والإقتصاديت ب. 1. 
و هكذا نرى في هذه الفروض وتلك المسائل إلى أي مدى ينساوى الرجـلـ

$$
\text { و المر أة في الميراث. }
$$

ب- قد ترث المر أة نصيبا أكبر من نصيب الرجل:

ذلك لو كانت مكان الرجل الذي هو في درجتها ومع كـلـ مــنهم نفـس

الورثة.

1- فمثلا لو نوفيت عن زوج وأم وأب وبنت، أو نوفيــت عـن زوج وأم وأب ، كأب

و ابن يكون المير اث كالآتي:

\begin{tabular}{|c|c|c|c|c|c|c|c|}
\hline \multicolumn{4}{|c|}{ المسألة الثانية } & \multicolumn{4}{|c|}{ المسألة الأولى } \\
\hline الأنصبة & السهام & الفروض & الورثة & الأنصبة & السهام & | الفروض & الورثة \\
\hline 11 & r أسهم & ربع & زوج & 11 & r أسهر & ربع & زوج \\
\hline ir & سهمان & سدس س & أب & ir & سهمان & سدس & أب \\
\hline ir & سهمان & سدس س & أم & Ir & سهمان & سدس س & أم \\
\hline$r$. & ه أسهر & الباقي & ابن & r & ד أسهر & نصف & بنت \\
\hline
\end{tabular}

فلو كانت التزكة في كلا المسألتنين Y فدانا لأخذت البنت فـي المسـألة

الأولى بr فدانا و أخذ الابن في المسألة الثانية .ب فدانا.

مجلتّ البحوث القانونيت والإقتصاديت . 


$$
\text { و وكذا نرى أن البنت نأخذ أكثر من الابن لو كانت مكانه. }
$$

ץ- ولو توفيت عن زوج و أم و أختين شقيقتين أو أختين لأب، أو توفيــت عـن

$$
\text { زوج وأم و أخوين شقيقين أو أخوين لأب. }
$$

\begin{tabular}{|c|c|c|c|c|c|c|c|}
\hline \multicolumn{4}{|c|}{ المسألة الثانية } & \multicolumn{4}{|c|}{ المسألة الأولى } \\
\hline الأنصبة & السهام & الفروض & الورثة & الأنصبة & السهام & الفروض & الورثة \\
\hline$r \varepsilon$ & أسهر & نصف & زوج & 11 & $\begin{array}{c}\text { أسهر } \\
\text { L }\end{array}$ & نصف & زوج \\
\hline$\wedge$ & سهم & سدس & أم & 7 & سهم & سدس & أم \\
\hline 17 & سهمان & الباقي & شأخ أويقن & $r \varepsilon$ & $\begin{array}{c}\text { أسهر } \\
\text { أسهر }\end{array}$ & تلثين & أختيقتين \\
\hline
\end{tabular}

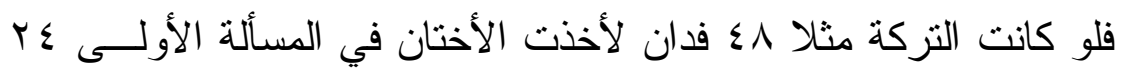

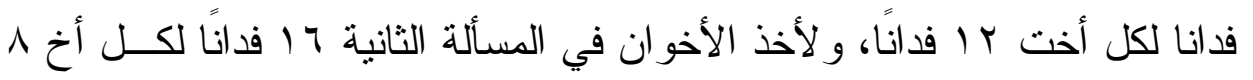
أفدنة. 
و هكذا نجد أن الأخت تأخذ أكثر من الأخ لو كانت مكانه.

r- ولو توفيت عن زوج و أم و أب وبنتني، أو نوفيت عن زوج وأم وأب و ابنين:

\begin{tabular}{|c|c|c|c|c|c|c|c|}
\hline \multicolumn{4}{|c|}{ المسألة الثانية } & \multicolumn{4}{|c|}{ المسألة الأولى } \\
\hline الأنصبة & السهام & الفروض & الورثة & الأنصبة & السهام & الفروض & الورثة \\
\hline$r$. & r أسهر & ربع & زوج & $T \varepsilon$ & r أسهر & ربع & زوج \\
\hline$r$. & سهمان & سدس & أب & 17 & سهمان & سدس & أب \\
\hline$r$. & سهمان & سدس & أم & 17 & سهمان & سدس & أم \\
\hline 0. & ه أسهم & تعصيبا & ابنين & $7 \varepsilon$ & $\wedge$ & فرضا تلثين & بنتين \\
\hline
\end{tabular}

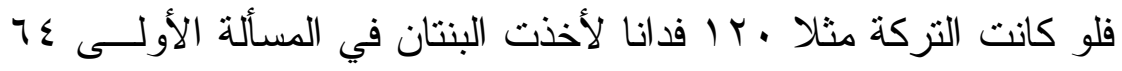

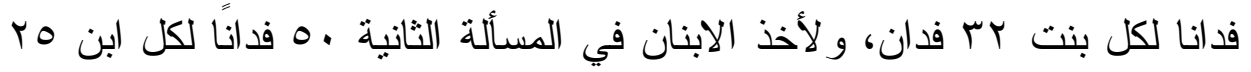

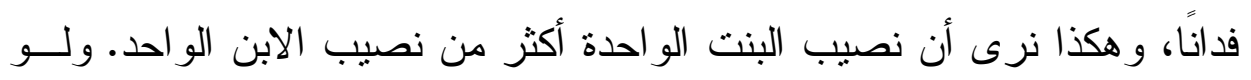
كان مكان الأبناء والبنات أبناء أبناء، وبنات أبناء لم يتغير الحكم.

ـ- ولو توفيت عن زوج و أختين لأم و أخوين شـقـقين أو أخــوين لأب. لأخـــ

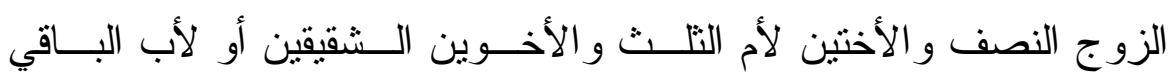

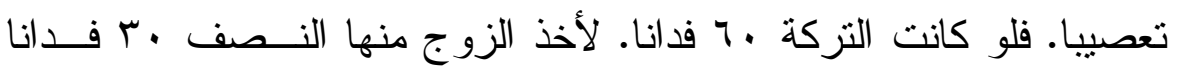

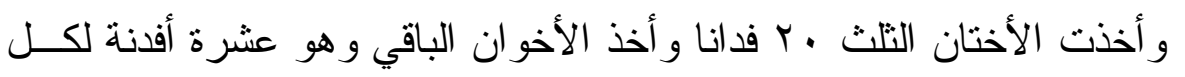

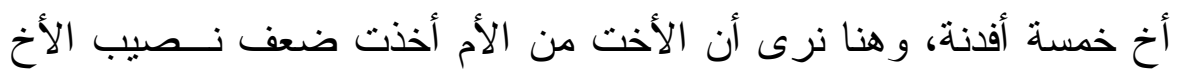


الثقيق مع أنه أقوى قر ابة منها حيث أخذت عشرة أفدنة وهو أخــذ خمـسـة

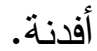

و وكذا نرى أن التطبيقات العملية و الكثير منهـــا تـسفر عـن أن المــر أة

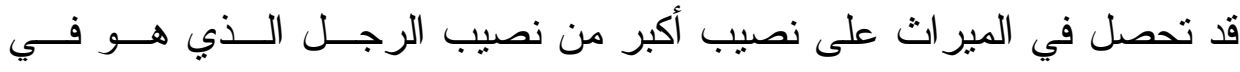

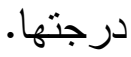

\section{ج - قد ترث المرأة ولا يرث الرجل شيئًا:}

قد ترث المر أة نصييها بالفرض في حين لا يرث الرجل الذي هــــــــي درجتها لو كان مكانها وذللك كما لو :

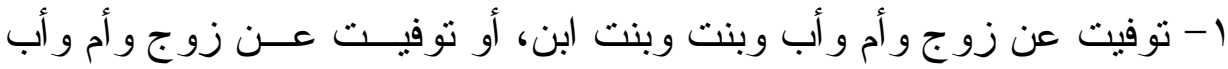
وبنت و ابن ابن لكان المبر اث كالآتي:

\begin{tabular}{|c|c|c|c|c|c|c|c|}
\hline \multicolumn{4}{|c|}{ المسألة الثانية } & \multicolumn{4}{|c|}{ المسألة الأولى } \\
\hline الأنصبة & السهام & الفروض & الورثة & الأصبة & السهام & الفروض & الورثة \\
\hline$\leqslant 0$ & r أسهر & ربع & زوج & rq & r أسهم & ربع & زوج \\
\hline$r$. & سهمان & سدس & أم & ry & سهمان & سدس & أم \\
\hline$r$. & سهمان & سدس & أب & ry & سهمان & سدس & أب \\
\hline 9. & 7 & نصف & بنت & $\mathrm{VA}$ & T أسهم & نصف & بنت \\
\hline لا شيء & لا شيء & تعصييا & ابن ابن & ry & سهمان & سدس & بنت \\
\hline
\end{tabular}

مجلت البحوث القانونيت والإقتصاديت V 1. 
فلو كانت التركة مثنا 190 فدانا لأخذت بنت الابــن بr فــدانا تعــادل

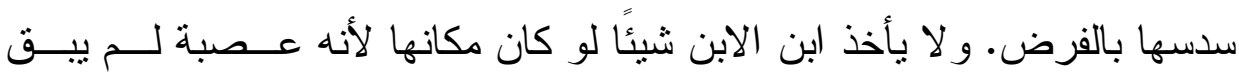

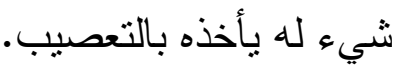
r- ولو توفيت عن زوج وأخت شقيقة وأخت لأب، أو توفيت عن زوج و أخــت شقيقة وأخ لأب لكان المير اث كالآتي:

\begin{tabular}{|c|c|c|c|c|c|c|c|}
\hline \multicolumn{4}{|c|}{ المسألة الثانية } & \multicolumn{4}{|c|}{ المسألة الأولى } \\
\hline الأنصبة & السهام & الفروض & الورثة & الأنصبة & السهام & الفروض & الورثة \\
\hline r) & r أسهم & نصف & زوج & 11 & r أسهر & نصف & زوج \\
\hline Y) & r أسهم & نصف & شقتة & 11 & r أسهر & نصف & شققة \\
\hline لا شيء & لألهيء & الباقي & أخ لأب & 7 & سهم & سدس & أأب \\
\hline
\end{tabular}

فلو كانت النركة بـ فدانا لأخذت الأخت لأب 7 أفننة ولو كان مكانها أخ لأب لم بأخذ شيئًا لأنه عصبة لم بيق له شيء. هذا ولو علدنا أن الفروض المقدرة في كتاب الله وسنة رسوله هي ســتة على سبيل الحصر و هي التنان و النصف و الثلث و السدس و الربع و الثمن. 


\section{ولو نظرنا في هذه الفروض الستة نجد الآتي:}

أولاً: أن الفرض الأكبر وهو التثلان: لا تستحقه إلا النساء، وهن أصناف أربعة: هن: البنتان فأكثر ، بنتا الابن فأكثر الأختان الثقيقتان فأكثر الأختــان مــن

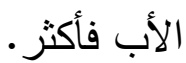

ثانيًا: أن النصف بستحقه من النساء أربعة وهن: البنــت، وبنــت الابنـوالأخـــت الثقيقة،و الأخت لأب هو لا يستحقه من الرجال إلا صنف و احد وهو الزوج فقط. ثالثًا: الثلث يستحقه صنفان من النساء هن الأم، و الأختين لأم فأكثر، ولــو كــان معهن أخ لأم لما تغير الحكم و أخذ الأخ لأم معهن منل نصيب و احدة منهن. رابعًا: أن السدس يستحقه من النساء خمسة أصناف وثلاثة فقط من الرجال. خامسًا: أن الربع تردد بين كل من الزوج و الزوجة. وهذا كله بالطبع عند نو افر شروط استحقاق كل وارث لفرضه.

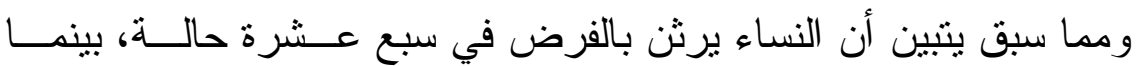

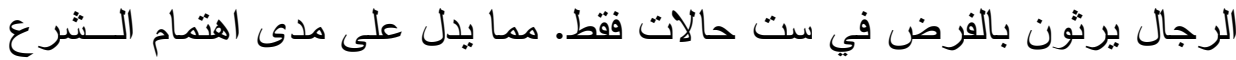

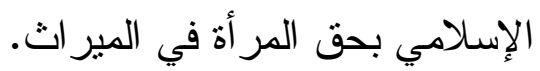

فهل يمكن القول بعد هذا كله أن يقول قائل أن الإسلام ظلم المر أة وبخسها

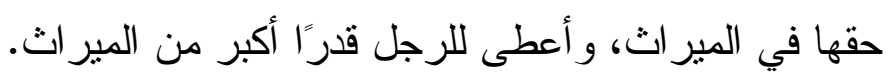

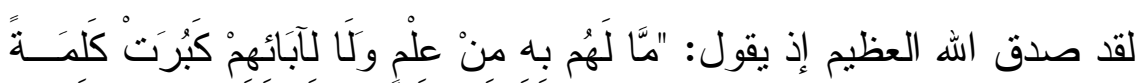

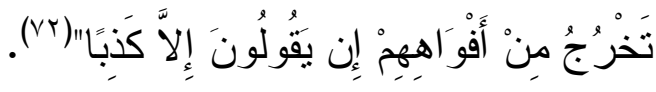

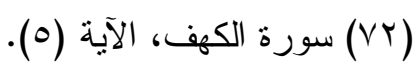





\section{المحور السادس}

\section{عقبات تحول دون حصول المر أة على حقها في الميراث}

إذا كان الثرع الإسلامي قد أنصف المر أة على النحو الذي عرضــناه إلا أن

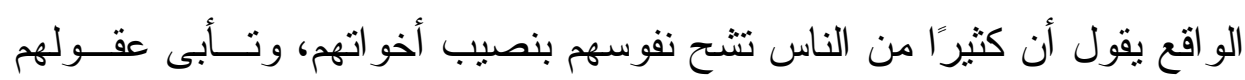

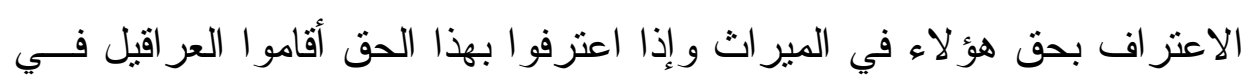

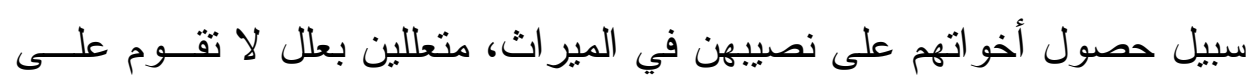

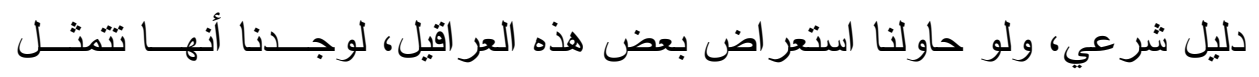
فيما يلي: ديلي

\section{أولاً: بقايا نزعة جاهلية وموروث باطل:}

إذا قلت لأحدهم لم لا تعطي أختك نصيبها في المير اث؟ يقول للك وكيف

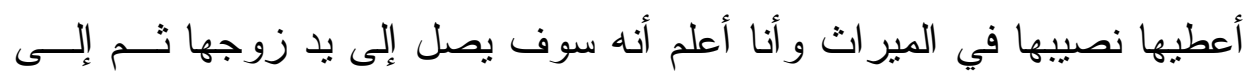

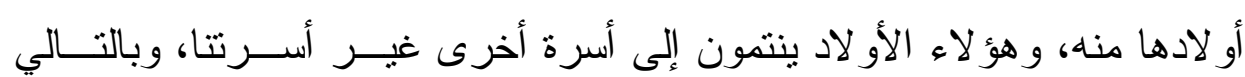

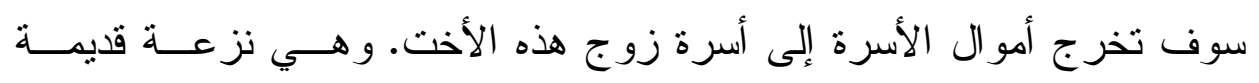

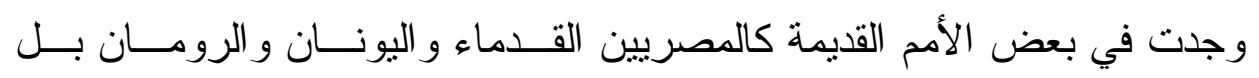
و اليهود. فطغت هذه النزعة على نفوس و عقول وقلوب هؤ لاء فعمتها عن رؤيـــة الحق.

مجلت البحوث القانونيت والإقتصاديت 111 
ثانيًا: الزعم بأن البنت قد أخذت حقها في حياة أبيهــا متـــثلا فــي تكــاليف

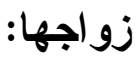

و هو زعم باطل لأن هذا الأمر لا فرق فيه بين الابن و البنــت، فــالابن

يزوجه أبوه في حياته غالبا وينفق عليه إلى أن يتزوج، بل إنه يتزوج ويعيش في

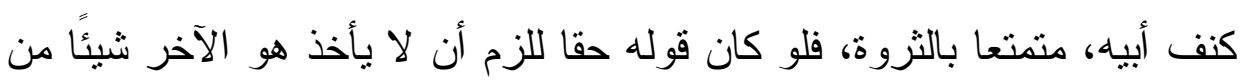

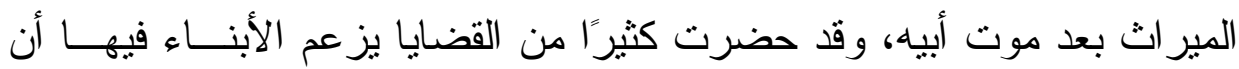
أختهم أو أخو اتهم قد حصلن على نصيبهن في حياة أبيهن أو أمهن وتجده يقــول

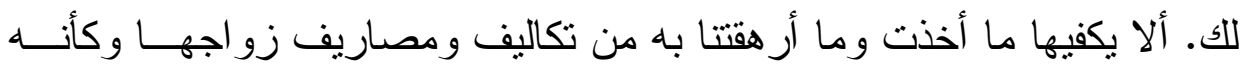
زوَّجها من ماله الخاص. - اص.

\section{ثالثًا: الطمع والأنانية وحب الاستئثار:}

فنجد الو احد منهم ينظر إلـــــــــروة أبيــهـ، متمنيـــا أن يقتــرب اليـوم

الذي يستأثز فيه بالمبر اث، وهو موت أبيه، فإذا مات اســتولى علـــى الميــراث

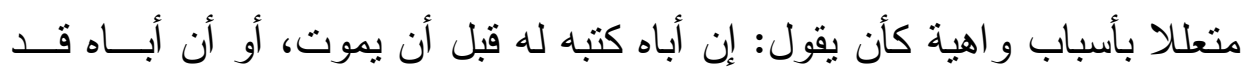

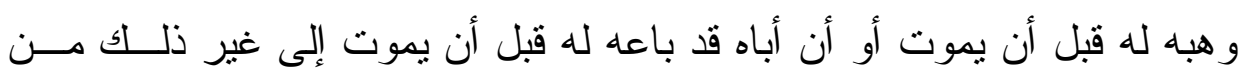

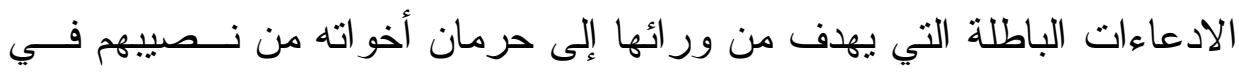

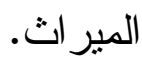

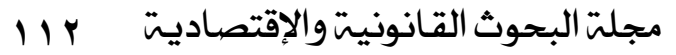




\section{رابعًا: ضعف الوازع الايني:}

فإذا ذهبت تعظه تجده يقول للك كفانا وعظًا. و إذا حاولت أن تذكره بمــا

يجب عليه نحو أرحامه نجده يقول للك: أنا لم أقصر مع أحد، وكفاهم ما أخـذوه

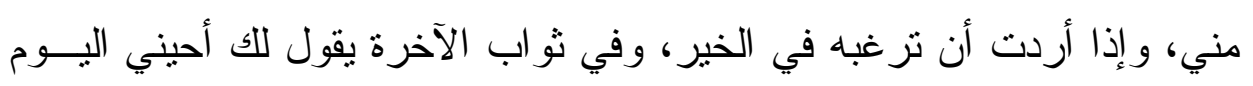

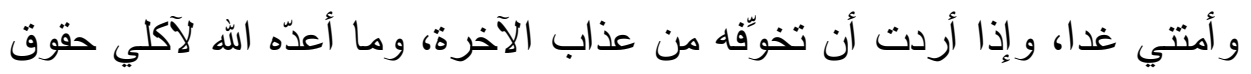

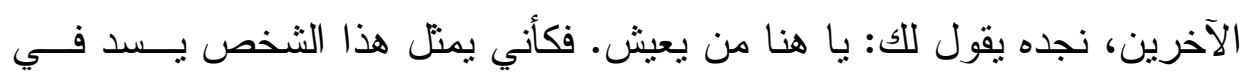

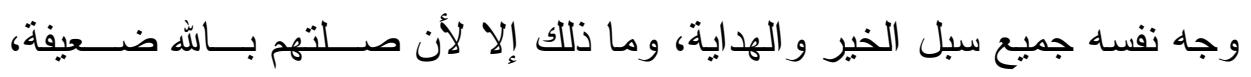
و ارتباطهم بالدين يكاد يكون معدومًا- و إحساسهم بالغير مفقودًا.

ولهؤل لاء وأولئك أقول: إن الله تبارك وتعالى لما قسم المواريث قال فـي

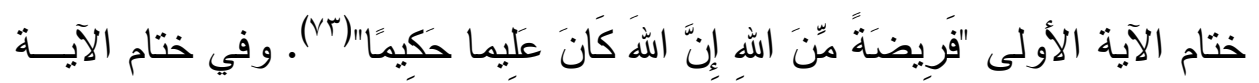

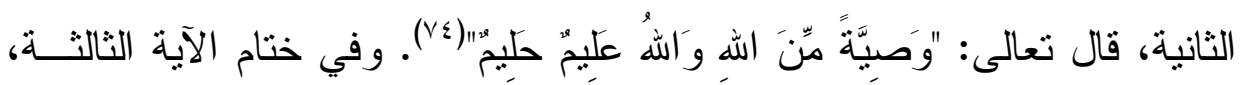

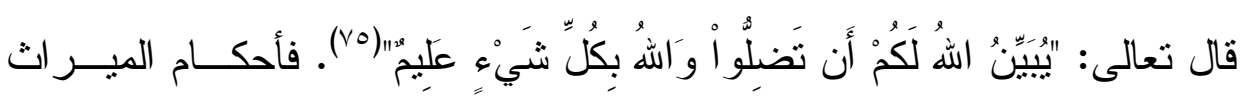

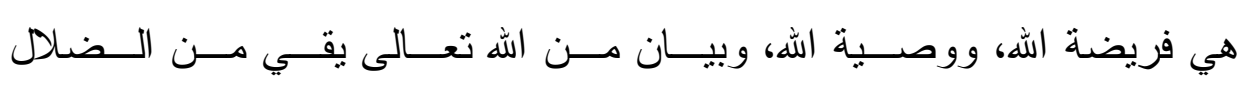
و الغو اية.

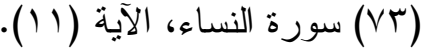

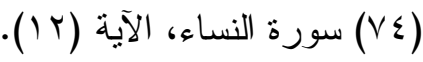

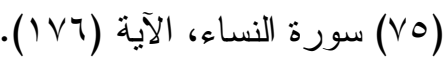

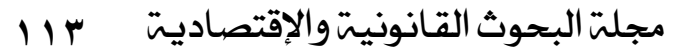




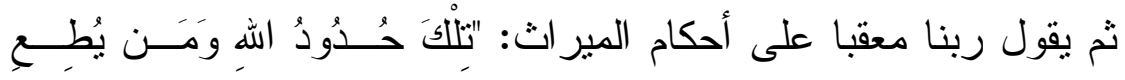

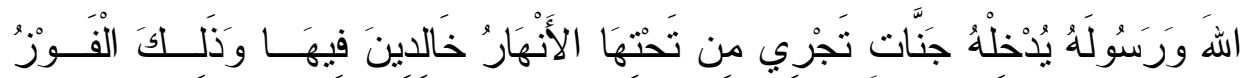

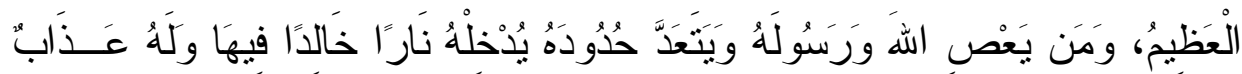

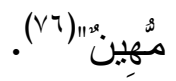

فأحكام المير اث التي شر عت بمقتضى القرآن و السنة ونــــوص قطعيـــة

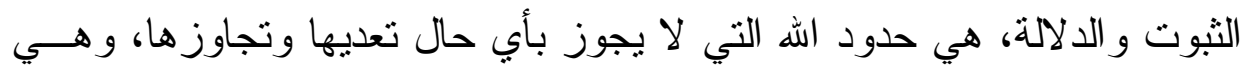

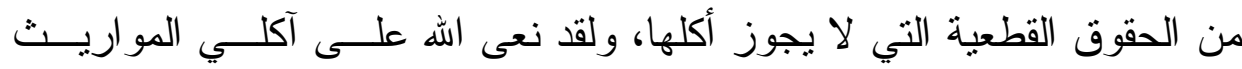
ومنكري حقوق الورثة، وذكر هم بالآخرة حين يققون بين يديه قال تعالى: "كَــاًَّ

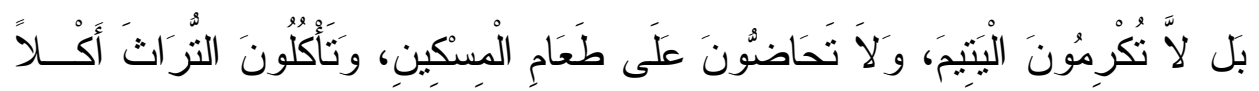

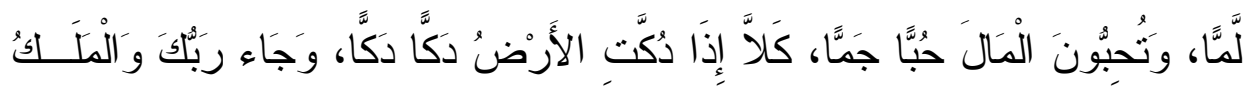

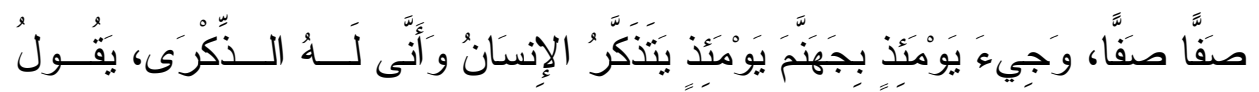

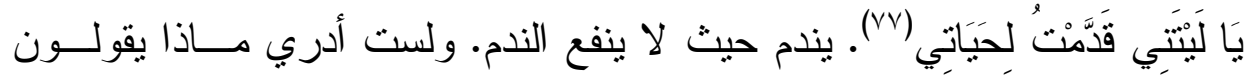

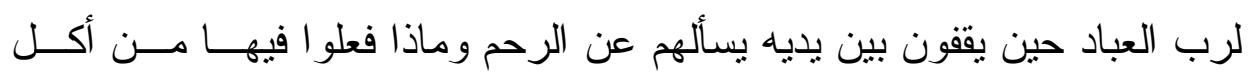

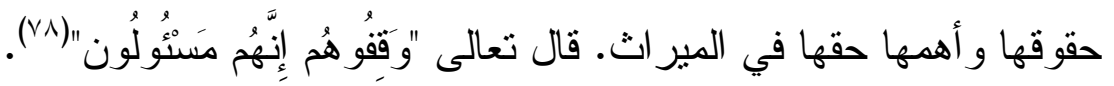

$$
\begin{aligned}
& \text { (VT) سورة النساء، الآيتان (T/، ع (IV). }
\end{aligned}
$$

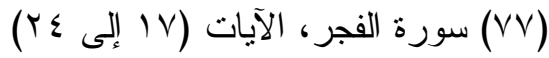

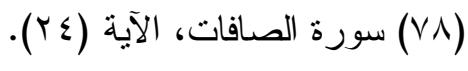

مجلت البحوث القانونيت والإقتصاديت ؛ 11 


\section{خامسًا: بطء إجر اءات التقاضي وتعقيدها:}

فإذا ضاقت السبل بصاحبة الحق في الميراث، وفثلت جميع مطالباتهــا

الودية، و اضطرت إلى اللجو ء إلى القضاء ذاقت الأمرين؛ بسبب تعقد إجــر اءات التقاضي من إعلام للور اثثة، ومحاو لات لإثبات الحق، وتعدد جلسات المحكمة من تأجيل إلى تأجيل ومن محكمة إلى محكمة ومن درجة إلى درجة وتظل قـ إنـايا

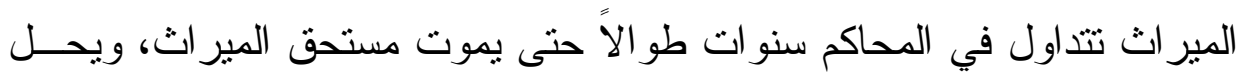
ورثثه محله، مما يضطر صاحبة الدعوى إلى أن تقبل بأقل القليل وتتتازل عـن لـن دعو اها و إنني لأعلم قضايا مير اث مرفوعة أمام المحاكم من بدايات الثمانينـات

$$
\text { وللآن لم يصدر فيها حكم. }
$$

و إذا حصلت صاحبة الدعوى على حكم لها بالمير اث لا تجد من ينفذ هـــا الحكم، وتجد من الطرف الآخر عنادًا وجحودًا، ولجوءًا إلى كافة الحيـلـل لعــدم تتفيذ الحكم كالطعن و الاستشكال إلى غير ذلك من الإجر اءات الطويلة و المعقدة. وللقضاء على تلك العقبة أرى:

أولاً: أنه يجب أن تكون الأحكام الصادرة في قضايا الميراث مـشمولة بالنفـــاذ المعجل و الجبري، وعرى جهات تتفيذ الأحكام، أن تقوم بتتفيذ هذه الحكــام بالقوة الجبرية. 
كذلك يجب إطلاق يد لجان فض المنازعات، ومجالس التحكيم العرفيــة، و اعنبار ما تتنهي إليه من أحكام، أحكامًا قضائية يخلع عليها القضاء الصفة لئة القضائية ويحيطها بالنفاذ المعجل ويلزم جهات تتفيذ الأحكام، بالعمل علـى بـى تتفيذها ولو بالقوة الجبرية.

ثانيًا: تخصيص دو ائر في محاكم الأسرة لقضايا المير اث من درجــات مختلفـــة حسب أهية النركة، وتعزيز هذه الدو ائر وتدعيمها بقوة شرطية متخصصة في تتفيذ الأحكام حتى يمكن تتفيذ أحكامها وتسليم المير اث إلى مستحقيه. هذا وأنني لأسأل الله أن تكون هذه السطور المنو اضعة مساهمة في حـل

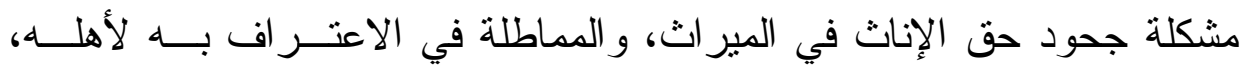
و إيصاله لمستحقيه، إنه تعالى من ور اء القصد ومنه النوفيق و السداد.. أ.د. الهادي السعيد عرفه 
قائمة بأهم المر اجع

$$
\begin{aligned}
& \text { 1- البخاري بشر ح السندي. } \\
& \text { r- بداية المجتهد ونهاية المقتصد لابن رشد. } \\
& \text { r- حاشية ابن عابدين. } \\
& \text { ع - حاثية الثرقاوي على التحرير • } \\
& \text { 0- الفو اكه الدو اني للنفر اوي. } \\
& \text { 7- المبسوط للسرخسي. } \\
& \text { - - مجمع الأنهر شرح ملتقى الأبحر - } \\
& \text { ᄉ- المغني لابن قدامه. } \\
& \text { 9- نيل الأوطار للشوكاني } \\
& \text { • ا-د. الهادي السعيد عرفه، أحكام التركات و المواريث في الفقـــه الإســلامي } \\
& \text { وقضاء النقض المصري. } \\
& \text { Iا -د. بدر ان أبو العينين، أحكام التركات و المواريث و المير اث المقارن. } \\
& \text { r ا-د. زكريا البري، المير اث في الثريعة الإسلامية. } \\
& \text { ب ا -د. زينب رضوان، المر أة بين الموروث و التحديث. } \\
& \text { ع ا -د. صلاح سلطان، التوازن بين حقوق المر أة فــي الميــر اث و النفقــة فــي } \\
& \text { الشريعة الإسلامية. }
\end{aligned}
$$

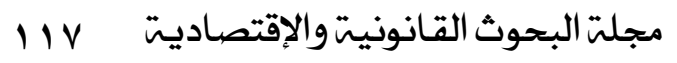




$$
\text { 10-د. عيسوي أحمد عيسوي، أحكام المواريث. }
$$

17 ا-د. محمد أحمد الدهمي، التوريث في الثريعة الإسلامية. IV 1 1-د. محمد يوسف موسى، المير اث في الثريعة الإسلامية. 